. $\pi \cdot \pi \cdot \pi \cdot \pi \cdot \pi \cdot \pi \cdot \pi \cdot \pi \cdot \pi \cdot \pi \cdot \pi \cdot$

\title{
THE MANAGEMENT OF
}

(10)

\section{GRASS LAND}

Wir

(1D)

s

?

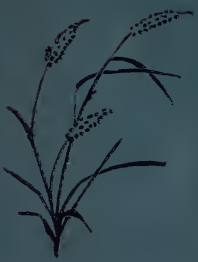

is

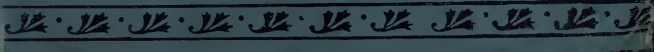


59-580733

SB 199

P.A.L. 58073

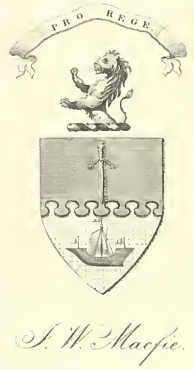

PERKINS

AGRICULTURAL LIBRARY

UNIVERSITY COLLEGE

SOUTHAMPTON 




\section{THE MANAGEMENT \\ OF \\ GRASS LAND,}

LAYING DOWN GRASS, ARTIFICIAL GRASSES, ETC. 


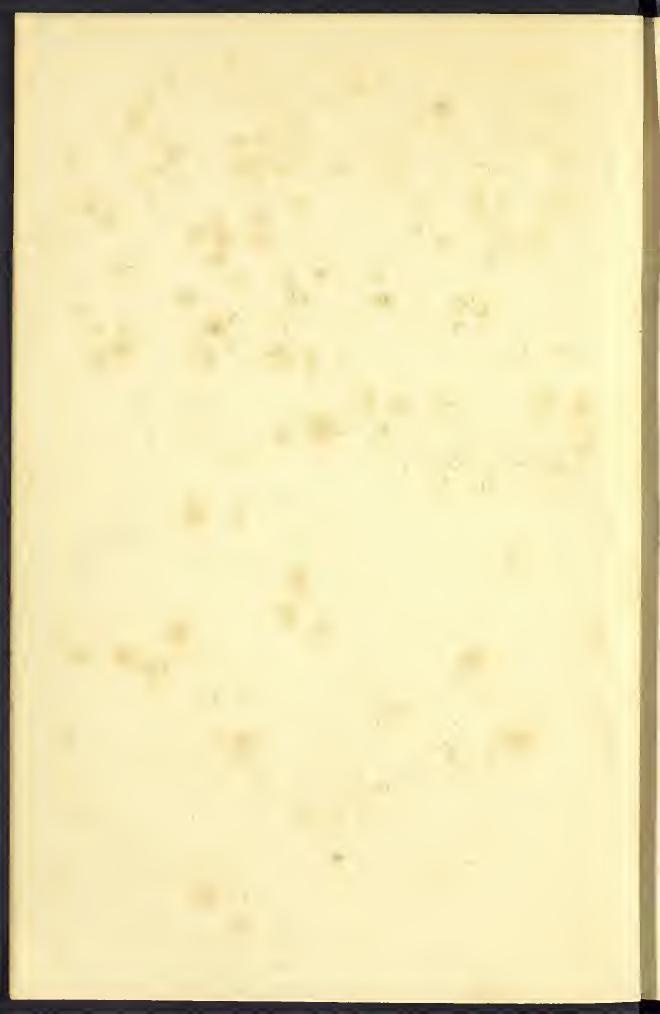


THE MANAGEMENT OF

\section{GRASS LAND,}

LAYING DOWN GRASS,

ARTIFICIAL GRASSES, ETC.

BY

ARTHUR ROLAND.

EDITED BY WILLIAM H. ABLETT.

ZLonขon:

CHAPMAN AND HALL, LIMITED.

I887. 
CHARLES DICKENS AND EVANS, CRYSTAL PALACE PIESS. 


\title{
CONTENTS.
}

\author{
CHAPTER I.
}

Misapplication of the Term "Grass"-Tribes of Grasses-

Leading Characteristics of some of the most useful Grasses-Meadow Fox-tail--Smooth-stalked Meadow Grass-The Meadow Cat's-tail-Crested Dog's-tailMeadow Fescue-The Tall Fescue-Sheep's FescueAnnual Meadow Grass-Wood Meadow Grass-The Creeping Poa-Rough Cock's-foot-Yarrow-Yellow Oat Grass-Sweet-scented Vernal-Fiorin, or Creeping Bent Grass-Rib Grass-Burnet-Meadow VetchlingPerennial Rye Grass-White Clover, or Dutch CloverNative Red Clover-Buttercup-Sorrel

\section{CHAPTER II.}

Aquatic Grasses - Flote Foxtail - Flote Fescue - Water Hair Grass-Reed Meadow Grass or Water Poa-The Miniature Lake-Renovating Old Pastures-Tables of Quantities of Seeds required per Acre-Tables of Seeds suited to each Geographical Formation

\section{CHAPTER III.}

The Conversion of Arable Land into Pasture-Preparation of the Land-Sowing the Seeds-Difference in the Weight of Grass Seeds - Time of Sowing - Spring Sowing-Laying down Turf by Transplantation-Improvement of the Quality of Grass Land 


\section{CHAPTER IV.}

Action of Manures and the Atmosphere upon Grass LandThe Meadows of Holland-Nitrogen in ManuresBoussingault's Opinions-Liebig's Deductions-Analyses of different Plants-Boussingault's Farm in Alsace - Meadow and Arable Land compared for Carbon and Nitrogen-Application of Manure to Meadow and Arable Land-Rotation of Crops in Alsace-Rotation of Crops in Bingen-Boussingault's Investigations-Dried Human Excrements-Dried Excrements in Egypt forming Sal-Ammoniac-Fields in the Valley of the Nile-Nitrogen found in Crops not in Proportion to that supplied in Manure-The Formation of Nitrogen depends upon the Presence of certain Substances contained in the Soil - Supplying Ammonia sometimes superfluous-Successful Farming ensured by the Appli-

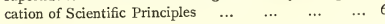

\section{CHAPTER V.}

\section{PARING AND BURNING.}

Pitting-Practice in Northamptonshire-Method in Ireland -General Principles-Method of Paring-Paring and Burning Bogs in Ireland-Favourable Estimation of Mr. Boys-Injurious to Poor, Shallow Soils-Beneficial

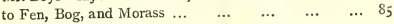

\section{CHAPTER VI.}

The Management of New Leys, or Grass Lands-Experiments described by Mr. George Sinclair-Autumnal Management-Appropriate Lands to remain in GrassRemoving Obstructions to the Scythe-Ant-hills$\begin{array}{lllllllll}\text { Mole-hills } & \ldots & \ldots & \ldots & \ldots & \ldots & \ldots & \ldots & 96\end{array}$ 
CHAPTER VII.

Mowing-Hay-making-The Middlesex Method of Making Hay-Wet Weather in Hay-making-Hay-making in Hot Weather-Relative Proportions of Grass and Hay - Stacking-To ascertain the Heat of a Stack of HayTo ascertain the Quantity of Hay in a Stack-Cutting the Stack and Trussing-Real Solid Food contained in

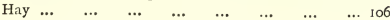

\section{CHAPTER VIII.}

Rowan or Aftermath-Fog and Fogging-The Gibbs Process of Saving Hay-Stock on Pastures

\section{CHAPTER IX.}

Artificial Grasses-Clovers-Varieties-Mixed Seed-Table of Proportionals of different Clovers in Crops-Unploughed Ground for Clover-Time of Sowing - Two Dangers - Manuring - Dr. Voelcker's Experiments Experiments upon Light Soil-Advantage of using a Mixture of Superphosphate and Muriate of PotashMowing Clover-Harvesting-Analysis of the Ashes of Clover

\section{CHAPTER $\mathrm{X}$.}

\section{LUCER NE.}

Preliminary Observations-Lucerne as an Article of Fodder - Growth of Lucerne on thin, Light Soils and Chalky Loams-Cleaning Lucerne with a Harrow-Lucerne in Wiltshire-Sowing-Hoeing-Harvesting-Mildew in Lucerne-Wide-standing Crops of Lucerne-Liability of Cattle to swell from eating Lucerne-Lucerne eaten by Fly-Analysis of the Ashes of T,ucerne $\quad \ldots \quad \ldots$ I60 


\section{CHAPTER XI.}

\section{SAINFOIN.}

General Remarks-Great Length of Sainfoin Roots-Preparation of the Land for Sainfoin-Sowing-Making Sainfoin Hay - Table of Acreage under Cultivation in Great Britain and Ireland-Analysis of Sainfoin Ashes

\section{CHAPTER XII.}

\section{TARES.}

Varieties - Application of the Crop - Sowing - Tares for Hay-Growing Tares for Seed-Analysis of the Ashes of Tares-Rye-grass - Sowing Rye-grass as Food for Stock-General Remarks-Analysis of the Ashes of Rye-straw-Rape and Cole-Affinity-Rape upon the Wolds of Yorkshire-Soil most fitted for Rape-Sowing - Use of the Crop-Cole-Cultivation in FlandersSeed-Mustard-Treatment while growing-As Food $\begin{array}{lllllllll}\text { for Sheep } & \ldots & \ldots & \ldots & \ldots & \ldots & \ldots & \ldots & 183\end{array}$ 


\section{THE MANAGEMENT OF GRASS LAND.}

\section{CHAPTER I.}

Misapplication of the term "grass" - Tribes of Grasses-Leading Characteristics of some of the most useful Grasses-Meadow Fox-tailSmooth-stalked Meadow Grass-The Meadow Cat's-tail-Crested Dog's-tail-Meadow Fescue-The Tall Fescue-Sheep's FescueAnnual Mendow Grass-Wood Meadow Grass-The Creeping Poa -Rough Cock's-foot-Yarrow-Yellow Oat Grass-Sweet-scented Vernal-Fiorin, or Creeping Bent Grass-Rib Grass-BurnetMendow Vetchling-Perennial Rye Grass-White Clover, or Dutch Clover-Native Red Clover-Buttercup-Sorrel.

FROM the somewhat exceptional condition of agricultural interests which prevail in this country, and have prevailed during the past few years, it is expected that for some time to come more than usual attention will be bestowed upon pasture land, and laying down arable land in grass, as well as the cultivation of artificial grasses, vulgarly so called in ordinary farming parlance, but to which Professor Lindley very properly takes exception, who points out that the name grass is very commonly misapplied, as in those instances when applied to clover, medick, sainfoin, \&c., which have no kind of resemblance to grasses proper, the latter being 
in all cases plants with narrow simple leaves, having a flat blade with numerous fine parallel veins, and a long sheath at the base, which represents the leafstalk, and through which the stem seems to pass.

Misapplacation of the term "grass."-The plants wanting these peculiarities the Professor points out are not grasses; and this being understood, there can only be two other orders of plants which can be mistaken for grasses, namely, sedges and rushes. Sedges, like grasses, have flowers composed of glumes and pales, either one or both, but they have the sheath of their leaf undivided, while in grasses, on the contrary, it is slit down one side. Rushes, when their leaves resemble grass, have flowers, composed of six parts or points, within which lie six stamens and a triangular ovary, containing several seeds; but in both grasses and sedges the ovary is a pulpy case, containing one seed, and no more. Thus in all real grasses the seed consists of a flat embryo lying on the outside of mealy or floury albumcn, and near the base, as in wheat; while in sedges it is a roundish body wholly enclosed within albumen at the base; and further, that the straw or stem of grasses is almost always hollow, while that of sedges and rushes is as constantly solid, or filled with a spongy pith.

The genera of grasses are thus distinguished by the structure of the parts of fructification, to which peculiar names are applied in the following manner: -The inflorescence is the part in which the flowers (spikelets) appear, and it receives different names according to the manner in which they are placed. The ear of wheat is a spike, that is to say, a collection of spikelets sitting close upon a common simple branch, 
called the axis, or rachis. The cluster of a poa, or meadow grass, or the branch of an oat, is a panicle, or collection of spikelets, each placed on a long stalk, so as to form a loose-branched inflorescence. The inflorescence of fox-tail, being composed of stalked spikelets, arranged compactly into the form of a close ear, is called a spikcd panicle. If the spikelets stand at a considerable distance, without stalks, upon a simple axis, as in Brachypodium sylvaticum, then the inflorescence becomes a pinnated spike.

The Professor proceeds to describe that the spikelets consist of scales or chaff, called glumes and pales, according to the position they occupy with respect to each other. The exterior scales, more or less different in texture, colour, and form from the interior, are the glumes. The interior, commonly in pairs, and immediately surrounding the stamens, are the pales. A spikelet may contain within its glumes one floret only, as in Agrostis, Alopecurus, and Hordeum; or two, as in Holcus; or several, as in Briza ${ }^{1}$ and Bromus; it is then said to be one-flowered, two-flowered, or manyflowered, and in distinguishing the genera of grasses, these differences are important.

Leading Tribes of Grasses for Husbandry Purposes. -As there are many modes of arranging the genera of grasses, Professor Lindley considers the most convenient for the purposes of husbandry to be that adopted by Mr. Babington in his Manual of British Botany,

1 A pretty grass which grows on poor soils, of every variety of texture, but of whose seerls only a comparatively small percentage will vegetate, but yielding a heavy crop without manure, which indeed appears to be hurtful to it, top-dressing having been known to have had the effect of extirpating it. 
of which the following is a modification, divided into eight tribes :-

SPIKELETS WITH ONE PERFECT FLORET, OR OCCASIONALLY WITH ADDITIONAL RUDIMENTS OF IMPERFECT FLORETS.

I. PANice E,-Spikelets compressed from the back, occasionally with a rudiment below the perfect floret.

2. Phalarides.-Spikelets compressed from the sides, with one or two rudiments, like glumes, below the perfect floret.

3. Phleiner. - Spikelets compressed from the sides, occasionally having a rudiment above the perfect floret. Inflorescence, a spiked panicle.

4. Agrostide/2.-Spikelets compressed from the sides, occasionally having a rudiment above the perfect floret. Inflorescence, a loose, open panicle.

5. ARUNDINEdE.-Floret enveloped in silky hairs.

6. Chlorides.-Spikelets compressed from the sides, placed in two rows on one side of a flattened rachis.

SPIKELETS WITH TWO OR MORE PERFECT FLORETS.

7. Avenine/E.-Florets covered with stiff hairs, their pales having a twisted kneed awn. Glumes as long as the spikelet.

8. FESTUCINE. E.-Florets comparatively naked, without a twisted awn. Glumes shorter than the lowest floret.

TRIBE I. PANICEE

Digitaria.-Inflorescence divided into flat, radiating, simple branches. 
Echinochloa.-Inflorescence compound, cylindrical, with the spikelets on one side of a flattened rachis.

Setaria. - Inflorescence compound, cylindrical. Spikelets surrounded by a ring of bristles.

\section{Tribe II. PhalarideE.}

Phalaris.-Glumes equal, with a broad membranous keel at the back.

Anthoxanthum.-Glumes very unequal, round at the back, one rolling up the other. Stamens, two.

\section{Tribe III. Phleines.}

Hordcum.-Glumes ending in long awns, spikelets sessile, in threes, a part often abortive.

Plilcum.-Glumes truncate, with a terminal bristle or point. Pales, two, without awns.

Alopecuris.-Glumes not truncate. Pales, one, with an awn at the back.

Lagurus,-Glumes ending in a long fringed bristle. Outer pale with a twisted awn at its back.

\section{Tribe IV. AgrostideE.}

Polypogon.-Glumes nearly equal, each with a long bristle from below the point. Outer pale, usually awned, shorter than the glumes.

Milium.-Glumes nearly equal, awnless. Pales hardening over the grain.

Agrostis.-Glumes very unequal, awnless, acute. Pales, two, unequal or one short, membrane, with or without an awn at the back. 


\section{TRIBE V. ARUNDINEA.}

Arundo.-Lower glume rather longer than the upper. Panicle loose. Silky hairs long. Outer pale awned.

Psamma.-Lower glume rather shorter than the upper. Panicle spike-like. Silky hairs short. Outer pale awned.

Phragmites.--Lower glume much smaller than the upper. Panicle loose. Silky hairs long. Floret, with several abortive ones below it. Outer pale awnless.

TRIBE VI. CHLORIDEE.

Cynodon.--Spikes arranged in radiating arms. Spartina.-Spikes arranged in an upright raceme.

TRIBE VII.-AVENINEE.

Aira.-Panicle loose. Glumes two-flowered. Outer pale tapering at the back, whence proceeds a sharp awn. (Usually the rudiment of a third flower is present.)

Corynephorus.-As Aira; but the dorsal awn is club-shaped and knee-jointed.

Trisetum.-Panicle close, spike-like. Outer pale with faint lateral veins, keeled, with two sharp teeth. Grain without a furrow.

Avena.-Panicle loose. Outer pale with strong lateral veins, and two points. Grain furrowed.

A rrhonathenum.--Lower floret male, with a long awn ; upper, hermaphrodite, with a short horn.

Holcus.-Lower floret hermaphrodite, awnless ; upper, male, with a dorsal awn. Pales hardening over the grain. 
Triodia.-Outer pale hard, leathery, round at the back, smooth, with three hard terminal points, and a broad intermediate tooth, sometimes producing a kneed awn.

\section{Tribe ViII. Festucines.}

Melica.-Glumes nearly equal, the upper with two or three ribs. Florets about two, rounded at the back, and hardening over the loose grain.

Molinia.-Glumes unequal, without lateral ribs. Florets, two or three, semi-cylindrical, hardening on the loose fruit.

Poa.-Outer pale with from three to five parallel ribs, thin at the point, compressed, keeled, and awnless.

Glyceria.-Outer pale with from five to nine strong prominent ribs, thin at the point, rounded at the back, and awnless.

Scleorochloa. - Outer pale with five faint lateral veins, membranous, cylindrical below, unarmed, often keeled at the tip. Glumes unequal, membranous.

Briza.-Florets short, broad, in two distinct ranks. Outer pale heart-shaped, boat-shaped, unarmed. Glumes nearly equal, thin, with a strong keel. Each spikelet with a comb-like bract at its base. Panicle spiked, one-sided.

Dactylis.-Outer pale compressed, keeled, with a very short bristle at the point. Glumes unequal, herbaceous, the larger keeled. Spikelets crowded, one-sided.

Festuca.-Outer pale rounded at the back, very sharp pointed, with slightly converging lateral veins. 
Glumes unequal. Styles terminal. Sheaths of leaves divided to the base.

Bromus.-Outer pale rounded at the back, with a long bristle proceeding from three ribs below the point. Glumes unequal. Styles lateral. Sheaths of leaves divided half way down.

Bracluppodium. - Like Bromus, but the spikelets sessile on a long axis, so as to form a pinnated inflorescence.

Triticum.-Inflorescence spiked. Glumes, two, turgid, equal. Spikelets on a zigzag rachis.

Secale.-Inflorescence spiked. Glume, awl-shaped. Only two florets perfect, the upper ones abortive. Spilielets on a zigzag rachis.

Lolium.-Inflorescence spiked. Glume,one. Spikelets placed edgeways on the rachis.

Elymus.-Inflorescence spiked. Glumes, two, on the same side of the spikelet. Spikelets, two or three, together.

Leading Characteristics of some of the most useful Grasses.-A large book could easily be filled with merely a simple description of the various grasses; but I shall content myself with giving a brief account of some of the characteristics of a few of the most useful grasses to the agriculturist.

Meadow Fox-tail (Alopecurus pratensis).-This is one of the earliest and best grasses produced in Great Britain, being distinguished by the largeness of its foliage, and by its producing a soft spike on a long stalk early in May, and grows with great luxuriance, being well adapted both for a first crop as well as for aftermath, which causes it to take rank amongst our most valuable grasses, whether fed off green or made 
into hay. It seeds abundantly, but they are seldom found in hay, as they are mostly shed before the other grasses are ready to be mown. There are two other species of fox-tail, and they thrive best on strong, inoist soils. The seeds of the meadow fox-tail are easily collected in the proper season, but they are very subject to the depredations of a small orangecoloured larva, or maggot, which feeds upon the germ.

Smooth-stalked Meadow Grass (Poa pratensis).This is one of the most useful grasses we have, the foliage shooting from a creeping root, and assuming a beautiful verdure early in spring. It keeps green in long-continued droughts, and vegetates in the driest soils, retaining its verdure during the winter, though not so productive as many others. As it only flowers once a year, it is considered a useful description for lawns, which are required to present an uniform appearance.

Rough-stalked Meadow Grass (Poa trivialis).This very much resembles the above in appearance, but its characteristics are widely different, for while the former succeeds in dry land, the rough-stalked is mostly found in moist meadows, being injured by excessive drought. It grows to a great height, and affords abundant herbage.

The Meadow Cat's-tail, or Timothy Grass (Phleum pratense). - The seed of this grass has been largely imported into England from America, and when first sent over was supposed to be a new species. In the United States it is extensively cultivated by itself, unmixed with other grasses, and produces large crops on moist and rich loams, and peaty soils. There are two kinds, the larger and the lesser, the first being 
best adapted for pastures of good quality, and the latter being well adapted for winter food upon poorer soils. It yields abundantly during the summer, and is much liked by cattle if well kept down by close feeding; but if intended for hay, it should be cut before it comes into flower, otherwise the stems become very coarse.

Crested Dog's-tail (Cynosunus cristatus). - This variety is well adapted for dry situations, sandy or calcareous soils, and will not thrive in moist situations. In dry, upland pastures it forms a thick, short turf, giving good feed for sheep, flowering about the end of June or beginning of July. The variety known as blue dog's-tail, found upon the tops of high limestone rocks, is one of the earliest grasses, and standing the summer drought, is on this account very useful, but is not of a kind that can be recommended for general culture, for though sheep are said to relish it very much, cattle do not care for it.

Meadow Fescue (Festuca pratensis). - This is more succulent than the tall fescue grass, bearing broad leaves, and is very hardy. It is somewhat coarse, with a hard stem, but grows quickly, and is liked by all kinds of cattle, flowering about the middle of June, and making excellent hay. It succeeds admirably upon well-drained clays, loams, and active peat soils, and upon any land that is not too dry. The seeds, which are abundant, are easily collected.

The Tall Fescue (Festuca elatior). - This is a large and vigorous plant, so that upon pastures where it principally prevails, two tons of hay to the acre are often mown, and succeeds well upon loamy clay and calcareous, loamy sand. 
Sheep's Fescue (Festuca ovina).-Although this description has been recommended for sheep, it is said they will leave it when they can procure other food, though it is very commonly found upon down land, forming a thick turf on dry sandy soils and elevated land.

Annual Meadow Grass (Poa annua).-Cattle of all kinds are very partial to this grass, which has a beneficial effect upon milch cows especially, improving the quality of the butter; but it has the drawback of a comparatively small yield. It is not a permanent grass, as would be inferred from its name, but it flowers at different periods throughout the summer, and, continually producing seeds thus, either when fed off or mown, which spring again, the result is the same as if it was perennial.

Wood Meadow Grass (Poa nemoralis). - This variety flowers beneath the shade of trees, thus possessing a somewhat exceptional quality, which is highly useful in a meadow closely surrounded by plantations or trees in any form. It is, however, likely to be overpowered by other grasses.

The Creeping Poa (Poa compressa). - This is considered a very useful grass, flowering during the greatest part of the summer, its dark green leaves springing up closely together, forming a thick turf, which, though short, is said to be of such excellent quality as to cause the flesh of the sheep which are fed upon it to have a more delicate flavour than usual.

Rough Cock's-foot (Dactylis glomerata). -This is a capital grass to be sown in orchards, as it thrives under the shade of trees. It springs early, which is another recommendation, and offers early feeding for 
young stock or milch cows that may need an early bite of grass. It grows freely upon land of a medium quality, where it is commonly met with, but does not succeed upon chalky downs or stiff, wet clays. When young, both sheep and cattle like it, but it needs to be kept down, or otherwise it grows up in large tufts and overpowers the other grasses, and if allowed to stand too long becomes rank, and grows very coarse, in which condition it will be rejected by stock. It should be cut early and made into hay, as it springs quickly afterwards, and yields an abundant aftermath.

Yarrow (Achillea millefolium).-A very common grass, found growing amongst the best pastures, a favourite with all kinds of stock, though its presence is often not suspected, as it is cropped down closely as fast as it springs, it being supposed to possess qualities beneficial to cattle, which cause them to appropriate it readily, though probably not affording much nutritive support, a prejudice at one time even existing against it. It stands drought well, and flowers about the end of June or beginning of July.

Yellow Oat Grass (Avena flavescens).-This grass grows on soils of very varied description, and, as it does not flower before July, is generally made into hay before it gets too old and coarse, in which form it is objectionable, and is therefore not a good one to use in the formation of a permanent turf, some considerable difference of opinion prevailing as to its value.

Sweet-scented Vernal Grass (Anthoxanthum odoratum). - This is neither a very productive, nor a very nutritive grass, nor is it much liked by stock when eaten alone, but it gives the agreeable perfume to new 
hay, and is the only fragrant grass natural to our fields, and forms part of the herbage on all good meadow-land, and is one of the earliest grasses, growing upon almost any kind of soil. As its chief value lies in communicating an agreeable flavour to hay, a certain quantity of the seed should always be sown with permanent grasses.

Woolly Soft Grass, or Yorkshire White (Holcus lanatus).-This has been a good deal resorted to for sheep-walks, growing vigorously in moist sandy spots about the end of June, as well as a similar variety (Holcus mollis, or common soft grass); but though useful in certain situations for sheep, it is said to be positively deleterious to horses when taken in any quantity, causing a too copious discharge of urine, and bringing on prostration.

Fiorin, Creeping Bent Grass (Agrostis stolonifera).This grass is a somewhat remarkable one, and is often inserted amongst the list of aquatic plants on account of its thriving in a most luxuriant degree upon cold clays, very wet soils, bogs, \&c., coming into the greatest perfection in a humid climate, where the yield is very large per acre; but there is no soil so poor where it will not grow, its roots penetrating but a short distance into the soil, which proves that its chief support is derived from the atmosphere.

It was brought into prominent notice by the Rev. Dr. Richardson, of Clonfeele, in the county of Antrim, for previously it had only been recognised as a weed, putting out a great profusion of lateral strings, something like the strawberry plant; and as every jointed portion has the power of vegetation, when given to cattle green upon the soiling system, care has to be 
taken that undecomposed portions are not put upon the dunghill, and afterwards spread upon the arable land, as it is hard to get rid of.

Its productive power is so great that six tons of hay per acre have been made from it, its chief recommendation being that it will grow luxuriantly in low and swampy land, upon which scarcely anything else could be grown profitably. It grows in such large quantities in irrigated meadows that are favourable to its production, that its yield has been known to be four times as much as any other grass. All cattle are extremcly partial to it, and will prefer the hay made from it to any other. From the length of time that it vegetates, it can be used as green food throughout the greater part of the winter.

The seeds are of very slow growth, and it is therefore usual to propagate by planting cuttings of the strings, which vary in length from one to ten feet, and can be done any time between the roth of September and the Ist of April, the strings being laid on a bare surface and then lightly sprinkled over with earth or compost, peat ashes and earth well mixed being often used. The cuttings are prepared by twisting the strings into a kind of loose rope, and then chopping them up in pieces upon a board into lengths of between three and four inches. Although liking a wet soil, it does not succced in stagnant water, and when the crop comes up, it should be carefully weeded during the first year of its growth, as it is likely to be overpowered by weeds. On cold clay land that is too heavy for the growth of turnips, Fiorin might often be planted to advantage, its most valuable quality being the production of green food throughout the winter; 
but it should be planted alone, and not in conjunction with other grasses, it being open to the objection of neither supplying spring feed, nor producing a second crop within the same year, its chief recommendation consisting in its furnishing a green crop from the beginning of October till the end of March, not admitting of being pastured, but when cut, and given to cows, increases the flow of milk, and imparts to it greater richness.

Rib Grass (Plantago lanceolata).-This grass produces a considerable amount of herbage on loams and rich sands, and in mountainous districts has covered with verdure what otherwise would have been only bare rocky elevations, but a good deal of difference of opinion exists as to its value. In the Cheshive Report it is stated that, if sown with clover it is the means of preventing cattle from being hoven.

Burnet (Poterium sanguisoiba). - This is considered a useful grass when mixed with others in elevated situations, when it stands the effects of winter well, and it possesses an aromatic property, and is doubtless a tonic, and therefore generally found cropped close down to the ground when growing with other grasses, but by itself it is coarse and unpalatable, though often raised alone. It has been grown to advantage upon poor chalky soils in conjunction with cock's-foot, as well as with small quantities of perennial fescue and meadow fescue, it being worthy of attention for chalky soils, though it grows as well upon sand and gravel.

Meadow Vetchling (Lathyrus pratensis) is a plant affording considerable bulk, and therefore when mixed with other grasses makes no inconsiderable addition 
to the hay-crop, though it flowers late, and is much relished by cattle.

Perennial Rye Grass (Lolium perenne) contains more than sixty varieties, and flourishes upon most kinds of soil, though it succeeds best when it is somewhat moist, but it grows under different methods of management in many upland situations, soon arriving at perfection, and producing early herbage that is much relished by cattle in the early part of the year.

It is sometimes sown with clover for a single crop in arable land, but the lattermath is inconsiderable, and it impoverishes the land. It has to a great extent been superseded by the use of Italian ryegrass, which is well known by its larger leaves, darker green colour, and greater height.

White Clover, Dutch Clover (Trifolium repens).This is one of the most general grasses throughout the country, growing everywhere, in rich and poor land alike, though in the latter its presence can often only with difficulty be discovered, as it is so minute, unless developed by top-dressings. It takes the name of Dutch clover from our first being instructed in its use by the Flemings who came over to England, and from the fact of large quantities of the seed being imported from Holland. Its favourite soil is limestone, and having a central root which penetrates to a great depth, it is enabled to resist drought well. It does not form good pasture when sown by itself, and is not so nutritive as the common annual red clover, but is an excellent addition with other grasses.

Native Red Clover (Trifolium pratense), which is also called in some districts "marle-grass," is perennial, 
while the red clover cultivated in arable land is only biennial. The cow-grass which bears a purple flower is still more permanent, and is therefore preferred to be sown amongst other grasses.

Buttercup (Ranunculas acris).-The buttercup is never eaten by cattle unless pressed by hunger, though it is often found in the richest pastures, and although interesting to children is by no means so to the farmer desirous of having the best plants growing upon his land that it is possible for him to obtain.

Sorrel (Rumex acetosa).-Another interesting plant to children under the designation of "Cock Sorrel," who eat it on account of the acidity of its leaves, but which cattle decline to do. Its presence in a pasture indicates acidity of the soil, which needs to be corrected by a dressing of lime. 


\section{CHAPTER II.}

Aquatic Grasses-Flote Fox-tail-Flote Fescue Water Hair GrassReed Meadow Grass or Water Pon-The Miniature Lake-Renovating old Pastures-Tables of quantities of Seeds required per acre-Tables of Seeds suited to each geographical formation.

THE grasses I have enumerated in the preceding pages comprise the leading kinds that demand the attention of the agriculturist, but there are also a few others that need to be mentioned, which are ranked amongst aquatic grasses which in wet land soon expel others that may have been sown in combination with them, so that wet lowlands or boggy soils require different kinds to those enumerated to be sown in them.

Aquatic Grasses.-There are many places where from certain causes it is impossible to get rid altogcther of the presence of water, when aquatic grasses may be resorted to with great advantage, and of these there are several useful kinds.

Flote Fox-tail (Alopocurus geniculatus) is peculiarly wcll fitted to grow in situations liable to inundations, occupying a place between the rough-stalked Poa and the Flote Fescue with respect to the degree of moisture which it will support. It is a creeping plant, which flowers in May and June, and is propagated by slips. It is often foupd in some of the moist meadows and marsh lands, and either in the form of green food or hay, stock will thrive upon it, and do well. 
Flote Fescue (Festuca fluitans). -Cattleareextremely fond of this grass, which may be seen growing indifferently in water and out of it, and they will often get themselves into awkward positions in their desire to obtain it. It springs early, and makes good fodder if cut in the sap. Another variety, festuca loliacea flowering in June and July, abounds at times in marshy situations, and although possessing a coarse, reed-like foliage, is considered a very useful grass.

Water Hair Grass (Aira aquatica).--This species may often be seen growing upon the margins of ponds and pools of standing water, as well as in moist situations that have not been well drained. It flowers in June and July, and milch cows are said to derive advantage from it, in the improvement of the quality of their milk and butter.

Reed Meadow Grass or Water Poa (Poa Aquatica).This is found a valuable grass in fen lands, and makes excellent food for cows, being held in high estimation for this purpose in many of the fen districts, sometimes attaining the remarkable height of six feet, though it is the usual practice to cut it and bind it up into sheaves when about four feet high. Horses do not care for it, but it furnishes abundant keep for cows, and in the Isle of Ely great store is set by it as food for them, being locally termed "fodder," when stacked and lightly fermented, in contradistinction to the other coarse grasses which are termed "stover."

Large tracts of land which used to be periodically overflown and put to little profitable use, are now made use of in growing this grass, and upon similar districts that are unfit for the support of the finer grasses this will be found an useful species to resort 
to. There is also another variety known as flote poa. To these may be added the creeping bent grass, or Fiorin, before described, which may well be ranked amongst the aquatic grasses, as it thrives best in moist situations, a full account of which was published some years ago by the Agricultural Society of the Stcwarty of Kirkcudbright.

I have never had the opportunity of making any experiments myself with these aquatic grasses, though for two or three years I had a piece of land that would have been very favourable for them.

The land before my house dips down in a succession of meadows towards a hollow, at the extremity of which is a somewhat deep gulley, which has been worn away by the stream of water that forces its way along after heavy rains, and carries away the surface water from the surrounding district. The land on the other side of the gulley rises precipitately, so that one has to clamber up a steep bank to get into the next meadows beyond. Part of the slope is occupied by a plantation of firs and an undergrowth of chestnut, which latter furnishes me with hop-poles when sufficiently grown, and at the bottom where the land feels the influence of the water, and is always moist, I have ash planted, and these grow thickly, and also furnish me with some capital hop-poles-I get my longest and straightest from this part of my plantation, which is fenced in with iron hurdles in a straight line, so that our view from the house is bounded on one side by the plantation in question, which we enter at the lower part by a swinging iron gate, which works in a curved portion of the fence, so as to keep out the cattle. 
The former proprietor had taken the pains to form a raised mound of some considerable size in the lower portion, or hollow of the meadow, some little distance from the plantation, this side of the gulley, and had planted it with trees, so as to form a pretty object from the windows of the house. After violent storms the water would not pass off quick enough in this portion of my low-lying meadow, the stream having force enough at times to carry down with it the trunk of a large tree, or any similar object, and would be spread in the lowest part of the meadow, about a couple of acres or so feeling its influence, and upon this part coarse rushes grew, and I did not then know how to deal with this land satisfactorily, for I had not read myself up, and become acquainted with the nature of the various grasses, and what I conceived a bright idea occurred to me at one time, and I resolved to make a miniature lake there, which is there now, and is certainly a great improvement, but I lost my opportunity of making experiments with aquatic grasses which I otherwise should have done.

The Miniature Lake.-Walking down this inclined portion of the meadow one day, when there was a good deal of water out, I could see that by making an embankment at the lower end, I could confine the course of the stream, and make a permanent lake of small size, and when it attained a certain level the water would pass off the top like a cascade, and I at once carried the project into execution. We collected all the stones we could find of large size, made a great number of faggots or fascines, and rammed them all firmly together with clay and earth, putting in also the trunks of a few trees to bear up against the 
pressure of the water, and driving down a stout pile here and there. It was a somewhat formidable job to carry out, but it was completed at last, being done in fine weather, and I anxiously awaited the result of the next thunder shower, when a large quantity of water would be sure to come down.

Returning from town one day after some heavy rain, I was rewarded with a sight of my "lake," which certainly was a great addition, and considerably added to the appearance of the place. The clump of trees stood out like an island from amidst the water, and I counted twenty-two of our white Aylesbury ducks that were swimming round it in a long line, and we were all altogether delighted with the improvement. It was about five feet deep in the lowest part, giving us just enough water to bathe comfortably in, and I had a good many cart-loads of fine sand brought down to form a bathing-place where the water was most conveniently entered. The neighbouring squire and his family were also very pleased with it, and during frosty weather the butler comes down and sweeps the ice, and makes it in nice order for the young ladies of the family to skate upon, who often avail themselves of this opportunity. We have to look to our embankment every now and then, when any signs of weakness show themselves, for if we were not to do this, I dare say in time the water would find its way out and force a passage through the obstruction; and while I cannot say I regret having made this miniature lake, which certainly improves the view from our windows, and is besides a source of amusement, I regret having lost the opportunity before I made it, of trying experiments with aquatic grasses on the couple of 
acres subject to overflow, which would have proved of great interest to me.

Renovating Old Pastures.-Thereare many meadows and upland pastures which can be greatly improved by the judicious sowing of seeds of the most productive perennial grasses suitable to the soil, together with clovers, \&c.

A writer on agriculture remarks that natural meadows are nowhere to be found, because all grass land which is in a state of nature, neither enclosed nor cultivated, is universally pasture. Many centuries probably elapsed before the invention of preserving grass by drying it into a state of hay; and this discovery which gave rise to what we call meadow, is supposed to have preceded that of tillage; though this may be considered somewhat doubtful, when we reflect that, in the primitive state of husbandry in this country, the cattle which were intended for consumption during the winter, were slaughtered in the latter end of autumn and salted for use. There is no doubt of the correctness of the theory as respects this country at all events, though it may not be applicable to the East, where pastoral occupations, down from patriarchal times, may have been the means of teaching many useful expedients in grazing-farming.

In Morton's Cyclopadia of Agriculture it is stated that, in the history of their cultivation, "the natural yield to the artificial grasses in precedency, red clover having been grown in England in 1645; sainfoin in 165 $\mathrm{I}$; yellow clover in 1659; white clover in 1707, and cow-grass about the same period. While the rye-grass appears to have been first cultivated in I677, and none of the other natural grasses for nearly 
a century, or about 1759 , when it was the practice with some of the more innovating practitioners, to sow along with the clovers, for permanent pasture, seeds shaken out of the best natural meadow hay. In $1761-64$ the cultivation of Timothy and cock's-foot grasses was introduced from North America. About the same period that of crested dog's-tail, sheep's fescue, and some of the bent grasses were first resorted to. And in 1766 a further stimulus toward the further cultivation of the natural grasses was afforded by the London Society for the Encouragement of Arts, Manufactures, and Commerce, bestowing prizes 'for gathering by the hand' the seeds of meadow fox-tail, meadow fescue, and sweet vernal grasses, which proceeding was very judiciously followed up in I 769 , by the same Society offering a gold medal 'to the person who should give the most satisfactory account of the different properties and comparative value of any two or more of the several natural grasses.' From the above date to nearly the end of the first quarter of the present century, few important additions seem to have been made either to the natural or artificial cultivated grasses, although their merits were ably advocated by most of the agricultural writers of those times, such as Curtis, Lord Kames, Dr. Anderson, Martin and Neddar, Young, \&c. But in I820 a new and most important stimulus to their cultivation was afforded by the late John, Duke of Bedford, publishing the 8 vo. editions of his Hortus Gramineus Woburnensis, being an account of the results of experiments, conducted in the Woburn grass garden, by Mr. George Sinclair, late gardener there, on the produce and nutritive qualities of different grasses and other plants, used as the food 
of the more valuable domestic animals, illustrated by numerous figures of plants and seeds, upon which these experiments were made, and practical observations on their natural habits, and the soils best adapted for their growth; pointing out the kinds most profitable for permanent pasture, irrigated meadows, dry or upland pasture, and alternate husbandry, accompanied with remarks on the character of the species and varieties."

Tables of quantities of seeds required per acre.-It has been proved by constant experience, that if a judicious mixture of grass seeds and other herbage plants are sown on a given space of ground, the yield per acre will be much larger than that produced from land where only two or three kinds are sown, by which both bottom and top herbage can be caused to grow.

The following tables are some, considered the most useful for my purpose, taken from the source I have just quoted (Morton's Cyclopadia of Agriculture), which the writer states, have been compiled chiefly from Lawson's treatise, On the Cultivated Grasses and other Herbage and Forage Plants, with the kinds and quantities of Seeds for sowing down Land, to Alternate Husbandry, Permanent Pasture, \&c. \&c., and a prize essay by J. D. Stirling, Esq., of Glenbervie, in vol. xv. of The Transactions of the Highland and Agricultural Society:

Column I. contains the scientific names.

Column II. contains the average weight of the seeds per bushel in pounds.

Column III. contains the average number of seeds in one ounce. 
Column IV. shows, in inches, the depth of cover at which the greatest number of seeds brairded.

Column V. shows, in inches, the depth of cover at which only about half the number of seeds brairded.

Column VI. shows, in inches, the least depth of cover at which none of the seeds brairded.

\begin{tabular}{|c|c|c|c|c|c|c|c|c|}
\hline \multicolumn{4}{|l|}{ I. } & \multirow{2}{*}{ II. } & \multirow{2}{*}{ 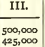 } & IV. & \multirow{2}{*}{$\frac{V .}{\frac{1}{2} \text { to } \frac{3}{5}}$} & \multirow{2}{*}{$\frac{V I}{1}$} \\
\hline $\begin{array}{c}\text { Agrostis stolonifera } \\
\text { vulgaris }\end{array}$ & $\cdots$ & $\begin{array}{l}\cdots \\
\ldots\end{array}$ & $\cdots$ & & & o to $\frac{1}{4}$ & & \\
\hline $\begin{array}{l}\text { yulgaris } \\
\text { Aira coespitosa } \ldots . . .\end{array}$ & $\dddot{. .}$ & & 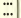 & 14 & $1_{32,000}$ & 0 to $\frac{1+}{5}$ & z to 1 & $\ddot{z i}$ \\
\hline lopecurus pratensis & $\ldots$ & & $\cdots$ & $\frac{5}{5}$ & 76,000 & - to $\frac{1}{2}$ & $I$ to $x$ & $2\}$ \\
\hline nthoxanthum odoratu & $\mathrm{um}$ & $\ldots$ & $\ldots$ & 6 & $7 x, 000$ & 0 to $\frac{\pi}{2}$ & $x$ to $x \frac{1}{4}$ & 4 \\
\hline urhenatherum avenac & ceum & $\cdots$ & $\cdots$ & 7 & $21, \infty \infty$ & $\frac{1}{2}$ to & I to to & 4 \\
\hline Brachypodium sylvace & eum & $\ldots$ & $*$ & 10 & 15,000 & 0 to $\frac{3}{2}$ & to to & 2 \\
\hline Cynosurus cristatus & $\cdots$ & $\cdots$ & $\cdots$ & 26 & 28,000 & 药 & & $\ddot{m}$ \\
\hline $\begin{array}{l}\text { Pactylis glomerata } \\
\text { glomerata, gi }\end{array}$ & igantea & $\cdots$ & $\ldots$ & $\begin{array}{l}16 \\
10\end{array}$ & $\begin{array}{l}40,000 \\
34,000\end{array}$ & $\begin{array}{l}0 \text { to } \frac{1}{6} \\
\ldots\end{array}$ & to $x$ & $2 t$ \\
\hline Elymus arenarius & ... & $\ldots$ & $\ldots$ & II & 2,320 & o to $I_{2}$ & $=$ to $2 \frac{1}{2}$ & $\ddot{5}$ \\
\hline geniculatus & $\ldots$ & $\cdots$ & $\cdots$ & 12 & 2,300 & ... & $\ldots$ & \\
\hline Festuca duriuscula & $\cdots$ & $\cdots$ & $\cdots$ & Io & 39,000 & o to $\frac{1}{3}$ & 電 to $\mathrm{I}$ & 21 \\
\hline elati & $\ddot{*}$ & $\cdots$ & $\cdots$ & $\mathrm{I}_{4}$ & 20,500 & o to & I to r & 27 \\
\hline pigante & & $\ddot{* *}$ & $\cdots$ & $\begin{array}{l}13 \\
12\end{array}$ & $\begin{array}{r}17,500 \\
33,000\end{array}$ & $\begin{array}{lll}0 & \text { to } & 1 \\
0 & \text { to } & 1\end{array}$ & 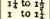 & 3 \\
\hline $\begin{array}{l}\text { heterophylla } \\
\text { gigantea }\end{array}$ & $\ldots$ & $\begin{array}{l}\cdots \\
\cdots\end{array}$ & $\ldots$ & $\begin{array}{l}12 \\
16\end{array}$ & $\begin{array}{r}33,000 \\
8,600\end{array}$ & $010 \neq$ & $x$ to $1 \frac{1}{4}$ & $\begin{array}{l}2 f \\
+28\end{array}$ \\
\hline ovina $\ldots$ & $\cdots$ & $\cdots$ & $+*$ & 14 & 64.000 & 0 to 1 & to to $I$ & 2 \\
\hline ovina tenuifoli & & $\cdots$ & $\cdots$ & 15 & 80,000 & ... & ... & $\ldots$ \\
\hline pratensis & $\ldots$ & $\cdots$ & $\ldots$ & $x_{4}$ & 26,000 & 0 to $\frac{1}{2}$ & $\frac{7}{8}$ to $x$ & $2 \frac{1}{2}$ \\
\hline pratensis loliac & icea & $\cdots$ & $*$ & 15 & 24,700 & $*$ & $\cdots$ & $\cdots$ \\
\hline $\begin{array}{l}\text { rubra } \\
\text { Glyceria aqua }\end{array}$ & $\cdots$ & $\cdots$ & $\begin{array}{l}\cdots+ \\
\cdots\end{array}$ & 10 & 39,000 & tö & z & $\ddot{2+1}$ \\
\hline $\begin{array}{l}\text { Glyceria aquatica } \\
\text { fluitans }\end{array}$ & $\cdots$ & $\ddot{*}$ & $\cdots$ & $\begin{array}{l}13 \\
x_{5}\end{array}$ & $\begin{array}{l}50,000 \\
33,000\end{array}$ & t... & \% 10 & $\cdots$ \\
\hline Holcus lanatus ... & $\cdots$ & $\cdots$ & . & 7 & 95,000 & $\frac{1}{4}$ to $\frac{1}{2}$ & 4 to $x$ & $2 \ddot{\xi}$ \\
\hline mollis ... & 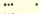 & $\cdots$ & $\cdots$ & 6 & 85,000 & ... & (3) & 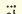 \\
\hline Lolium italicum .... & $\cdots$ & $\cdots$ & $\cdots$ & 15 & 27,000 & to & I. to $1 \frac{1}{3}$ & 3) \\
\hline .... & 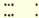 & $\cdots$ & $*$ & 18 to 30 & $\begin{array}{l}15,000 \\
80,000\end{array}$ & to $\frac{1}{2}$ & It to $I_{1}^{4}$ & $\frac{34}{25}$ \\
\hline $\begin{array}{l}\text { m effusurn .... } \\
\text { ris arundinacea }\end{array}$ & 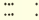 & $\cdots$ & $m$ & $\begin{array}{l}25 \\
28\end{array}$ & $\begin{array}{l}80,000 \\
42,000\end{array}$ & $\begin{array}{rl}+10 & 2 \\
\ldots & \end{array}$ & $\begin{array}{c}10 \\
\ldots\end{array}$ & $\begin{array}{l}25 \\
\cdots+\end{array}$ \\
\hline ense & $\ldots$ & $\cdots$ & $\ldots$ & 44 & $74, \infty 00$ & 0 to 1 & at to 1 & 2 \\
\hline Poa nemoralis ... & "̈* & $\cdots$ & $\cdots$ & I5 & 173,000 & *.. & min & $\cdots$ \\
\hline ralis semperv & virens. & $* *$ & $\ldots$ & $15 \frac{1}{2}$ & 133,000 & 0 to & to to $\frac{1}{2}$ & 1 \\
\hline $\begin{array}{l}\text { pratensis } \quad \ldots \\
\text { trivialis }\end{array}$ & $\cdots$ & $\cdots$ & $\ddot{*}$ & $\begin{array}{l}13 \\
15\end{array}$ & $\begin{array}{l}243,000 \\
217,000\end{array}$ & o to 1 & to to & $\dddot{x}$ \\
\hline $\begin{array}{c}\text { trnvialis } \\
\text { Psamma aruudinacea }\end{array}$ & $\cdots$ & $\cdots$ & 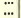 & $\begin{array}{l}15 \\
15\end{array}$ & $\begin{array}{r}217,000 \\
10,000\end{array}$ & $\frac{1}{2}$ to $x^{2}$ & I. to $x \frac{3}{4}$ & $\frac{12}{4}$ \\
\hline Trisetum flavescens & $\cdots$ & $\cdots$ & $\cdots$ & $5 \frac{1}{2}$ & II 8,000 & $0^{2}$ to & & 2 \\
\hline folium & & $\cdots$ & $\cdots$ & & 200,000 & $\frac{1}{t}$ to & 상 to 3 & 数 \\
\hline bus (chi & & $\cdots$ & $*$ & $3^{2}$ & $2 \pi, 000$ & 范 & $+t_{0}$ & i \\
\hline $\begin{array}{l}\text { piculatus } \\
\text { jor ... }\end{array}$ & $\ldots$ & $\ldots$ & $\ddot{*}$ & $\begin{array}{l}62 \\
64\end{array}$ & $\begin{array}{l}28,000 \\
5 \pi, 000\end{array}$ & $\begin{array}{c}0 \text { to } \\
\ldots . . .\end{array}$ & $+\ldots$ & $y$ \\
\hline Medicago lupulina & $\ldots$ & $\ldots$ & $\ldots$ & 63 & 16,000 & o to 1 & gat to $x$ & I \\
\hline & $\cdots$ & $\cdots$ & .. & 60 & 12,600 & $\ldots$ & ... & $\because$ \\
\hline & $\cdots$ & & & 26 & $I, 280$ & a to $x$ & 2 to $2 \frac{1}{6}$ & $4 t$ \\
\hline ativum & $\ldots$ & $\cdots$ & $*$ & 41 & 12,800 & $\ddot{*}$ & & $\dddot{7}$ \\
\hline eolata & $+\cdots+$ & $* .+$ & $*$ & $5^{2}$ & $x 5,600$ & $\frac{1}{7}$ to & & 2f \\
\hline ruisorba & burnet & & .. & 25 & 3,320 & $\frac{1}{2}$ to & It to 13 & 4 \\
\hline Trifolium fil: & $\cdots$ & $\cdots$ & $*$ & $\begin{array}{l}65 \\
63\end{array}$ & 54,000 & 0 to & to $\frac{1}{2}$ & $\begin{array}{l}\text { It } \\
\text { If }\end{array}$ \\
\hline & $\cdots$ & & $\ddot{*}$ & $\begin{array}{l}63 \\
64\end{array}$ & $\begin{array}{l}45,000 \\
16,000\end{array}$ & $\begin{array}{lll}0 & \text { to } \\
0 & \text { to } & 1\end{array}$ & It to $x \frac{7}{2}$ & $\begin{array}{l}15 \\
2\end{array}$ \\
\hline $\begin{array}{l}\text { prat } \\
\text { prat }\end{array}$ & renne & $\begin{array}{l}++* \\
\ldots .\end{array}$ & $\cdots$ & $\begin{array}{l}04 \\
64\end{array}$ & $\pm 6, \infty 00$ & 0 to & $x \frac{1}{3}$ to 1 & 3 \\
\hline repens & $\ldots$ & $\ldots$ & $\ldots$ & 65 & 32,000 & 0 to $f$ & 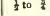 & $I \frac{1}{2}$ \\
\hline
\end{tabular}


SEEDS REQUIRED IN LBS. PER IMPERIAL ACRE.

FOR PERMANENT PASTURE.

lbs.

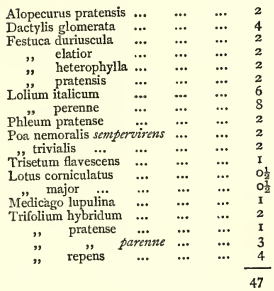

FOR PERMANENT LAWN PASTURES.

lbs.

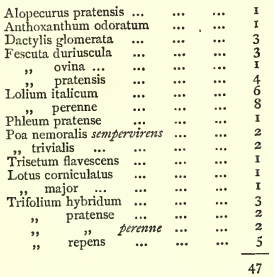


FOR FINE LAWNS, BOWLING GREENS, ETC., KEPT CONSTANTLY UNDER THE SCYTHE.

\begin{tabular}{|c|c|c|c|c|}
\hline Cynosurus cristatus & $\ldots$ & $\ldots$ & $\ldots$ & $\begin{array}{l}\text { lbs. } \\
\text { ro }\end{array}$ \\
\hline Festuca duriuscula & & $\ldots$ & $\ldots$ & 4. \\
\hline , ovina tcmuifo & & $\ldots$ & $\ldots$ & 2 \\
\hline Lolium perenne tenut & & $\ldots$ & $\ldots$ & 20 \\
\hline Poa nemoralis & & $\ldots$ & $\ldots$ & 2 \\
\hline$"$ trivinlis semper & rvirens & $\cdots$ & $\cdots$ & 2 \\
\hline Trisetum flavescens & $\cdots$ & $\cdots$ & $\cdots$ & I \\
\hline $\begin{array}{l}\text { 1nsetum flavescens } \\
\text { Trifolium repens }\end{array}$ & $\cdots$ & $\cdots$ & $\cdots$ & $\begin{array}{l}\mathrm{I} \\
6\end{array}$ \\
\hline " minus & $\cdots$ & $\cdots$ & ... & 2 \\
\hline
\end{tabular}

FOR PERMANENT PASTURE, ETC., HAY IN ORCHARDS, AND OTHER GROUNDS MUCH OVERSHADOWED BY TREES.

Anthoxanthum odoratum

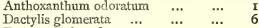

$\begin{array}{lllll}\text { Festuca duriuscula } & \ldots & \ldots & \ldots & 6 \\ & \ldots & \ldots & \ldots & 2\end{array}$

$\begin{array}{lllll}\text { elatior } & \cdots & \cdots & \cdots & 2\end{array}$

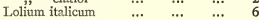

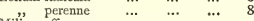

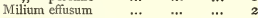

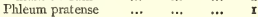

$\begin{array}{lllll}\text { Poa nemoralis } & \ldots & \ldots & \ldots & \text { 1 }\end{array}$

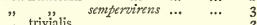

$\begin{array}{rrrrrr}\text { trivialis } & \ldots & \ldots & \ldots & \ldots & 2 \\ \text { Lotus major } & \ldots & \ldots & \ldots & \ldots & 2\end{array}$

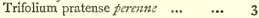

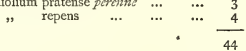

FOR PASTURAGE AND COVER IN THICK SHADY wOODS,

$\begin{array}{lllll}\text { Agrostis vulgaris } & \ldots & \ldots & \ldots & \text { I }\end{array}$

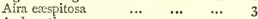

$\begin{array}{llll}\text { Arrhenatherum avenaceum } & \ldots & \ldots & \\ \end{array}$

Brachypodium sylvaticum $\quad \ldots . \quad \ldots .5$

Dactylis glomerata $\quad \ldots \quad \ldots \quad \ldots \quad$ 6

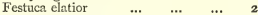

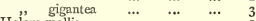

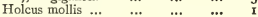

$\begin{array}{lllll}\text { Milium effusum } & \ldots & \ldots & \ldots & \text { 1 }\end{array}$

$\begin{array}{lllll}\text { Poa nemoralis } & \ldots & \ldots & \ldots & \ldots \\ \end{array}$

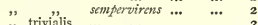

$\begin{array}{llllll}\text { Lotus major } & \ldots & \ldots & \ldots & \ldots & 2\end{array}$ 
FOR COVERING ROCKY, GRAVELLY, AND OTHER SOILS OF THE. WORST DESCRIPTION,

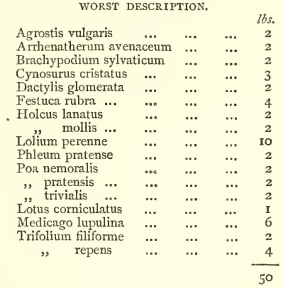

lbs.

FOR WARRENS OR LIGHT SANDY LINKS.

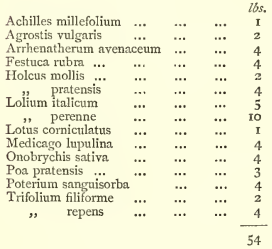

When fresh ground has been broken up for the purpose of being laid down in permanent pasture, it will be found the best plan, to ensure its being thoroughly clean, and made fit for the reception of grass seeds, to grow a crop of turnips, potatoes or other roots, on the land. The raising of this crop 
will be the means of getting it into good preliminary order, and will afford the opportunity of levelling and smoothing it effectually.

A still day should be chosen for sowing, when there is no wind to blow the seeds about, but of this I will speak again. The operation is generally performed with the common seed-barrow, but many men can do it very well by hand-sowing the light grass seeds, first passing up or down the furrows, and afterwards crossing the land and sprinkling it with the mixture of clover and other heavy seeds. It should then be bushharrowed, or a light iron harrow used, and carefully rolled. March, April, or May are the best spring months for sowing. If the seed is sown by the middle of March it will give the opportunity of discovering any bare places which the seed may have escaped, and over these some fresh seed should be sprinkled.

As soon as the young grass has attained a height of three or four inches, the roller should be again used, taking care that the soil is not too wet for the operation. The land should be rolled again once or twice before Christmas, and if the grass is strong, cattle may be put upon it in fine weather, but not when in a moist condition, for their hoofs would make indentations in it ; sheep should be kept away, as they are apt to pull up the young plants.

It is generally thought best, however, to leave it untouched till spring, rolling and bush-harrowing it in March, and let it rest till hay-making time. Two crops may then be taken, when the growth is luxuriant, cutting the first early, so as to give a good chance to the aftermath. It will then be in a good condition 
for grazing in the autumn. The early cutting checks the stronger-growing grasses, and gives the more slender kinds a better opportunity of thriving.

On very heavy land, Autumn sowing is sometimes desirable, and it is done in August or September, but there is a risk in late sowing of losing the clovers, which, are likely to be injured by frosts, or eaten by slugs.

In seeding old pastures, heavy harrows should be drawn over the turf to loosen the soil for the reception of the seed, in the early months of the year, February, March, or April, but the earlier the better, as the old blades protect the young shooting grass from frost, after which the land should be well rolled. If it is the intention to manure the field, the grass seeds should be sown upon the top dressing after it is thoroughly spread. The manure should be well rotted dung. If a portion is mossy, it is generally a sign that draining is needed, but a cure for this evil will be found in the application of quick lime, in the proportion of two cartloads of lime to eight of light loam per acre. This compost should be well mixed together, the lime having been slaked, and the pasture well dragged over with iron harrows.

If not done in the beginning of the year, the grass seeds should be sown immediately after the hay-crop is carried in July and August, when the grass is short from recent mowing.

With a view to economy, it is a common practice with some farmers to save and use the seeds which have accumulated in the hay-loft. But this is an unwise practice, as they consist chiefly of the worst grasses which are the only ones ripe at the time of 
hay-making, such as Holcus and Bromus, mixed with seeds of weeds which are detrimental to pastures.

It has been accurately determined which are the best kind of grass seeds suitable for each geological formation of the soil, and it will be found much more profitable to obtain the proper kind of seed from a respectable seedsman; the best seeds being always found the most economical to use in the long run; cheap and carelessly-gathered seeds being often mixed with deleterious ones, which causes it often to be necessary to expend a good deal of money afterwards in cleaning the land, and freeing it from undesirable growths in the shape of weeds; and this is more especially the case with grass, when the object is to lay down a permanent pasture of good quality.

Tables of seeds suitable for each geological formation. -Messrs. Sutton and Co., the well-known seedsmen of Reading, have paid much attention to this subject in the course of their business, and have issued a list of quantities of the various grass and clover seeds per acre, which it is desirable to use upon every description of land, which I herewith append. 


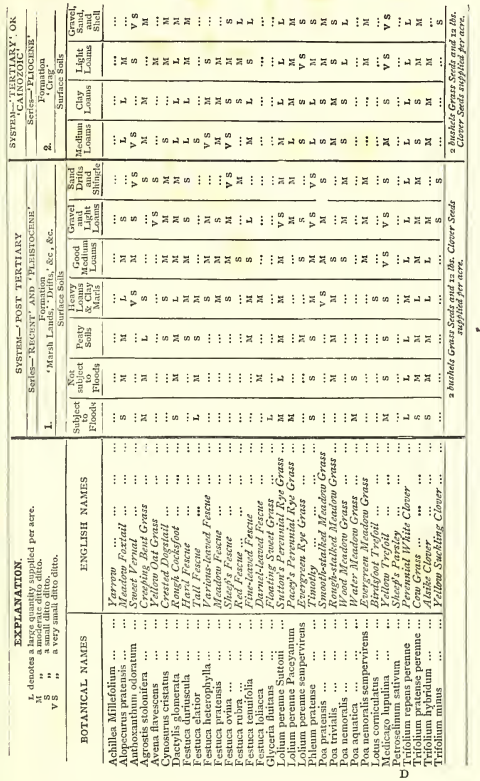




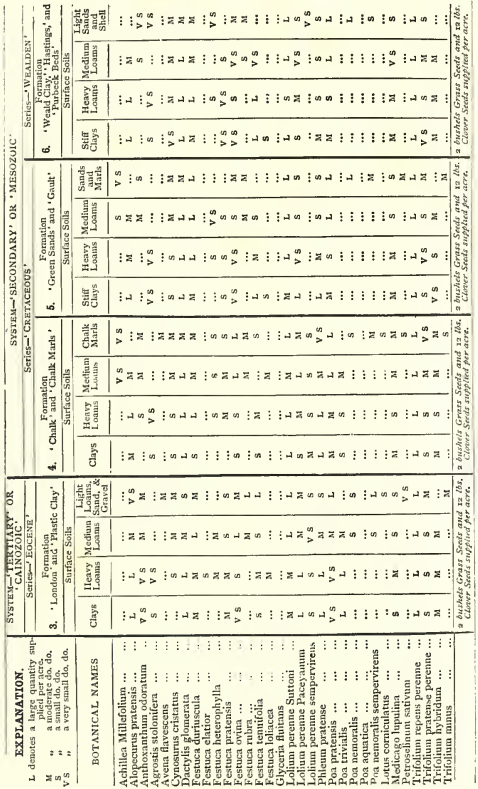




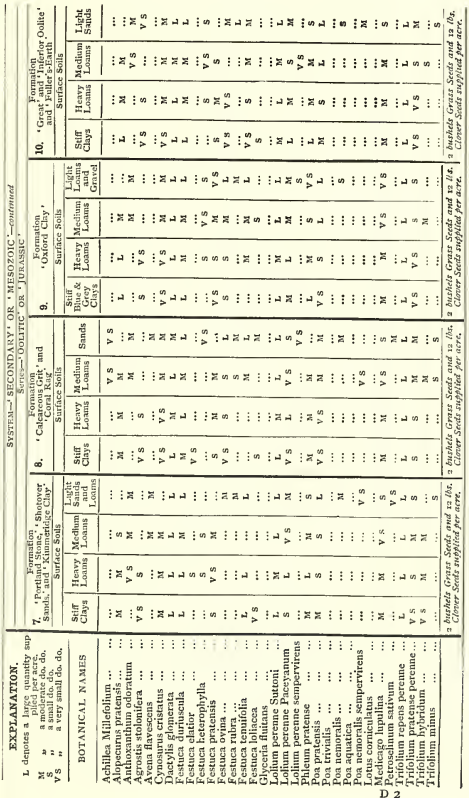




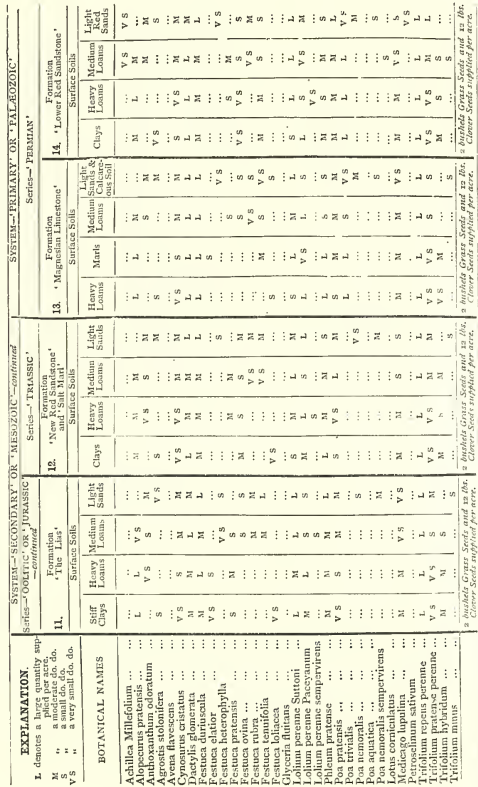




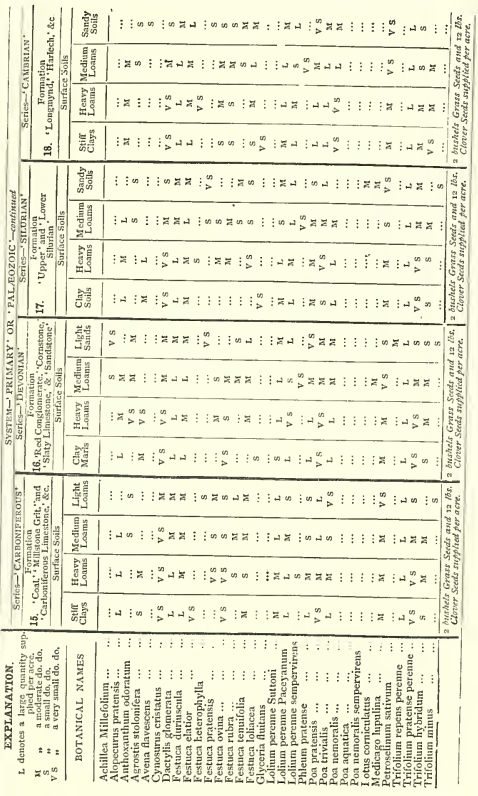




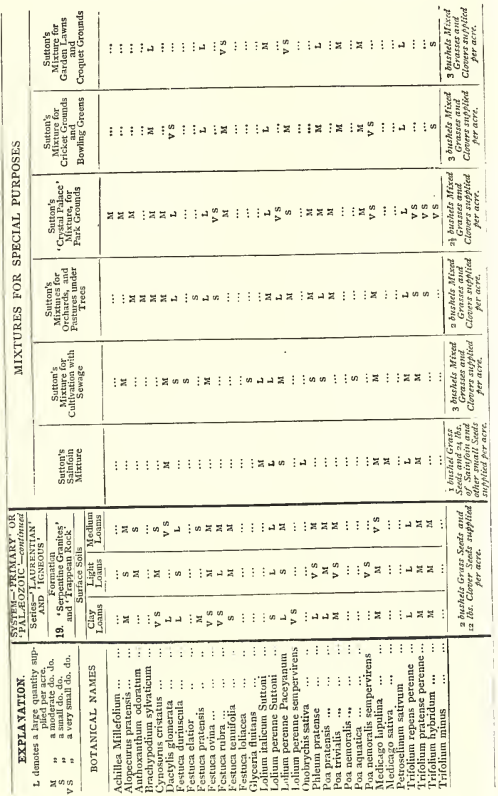




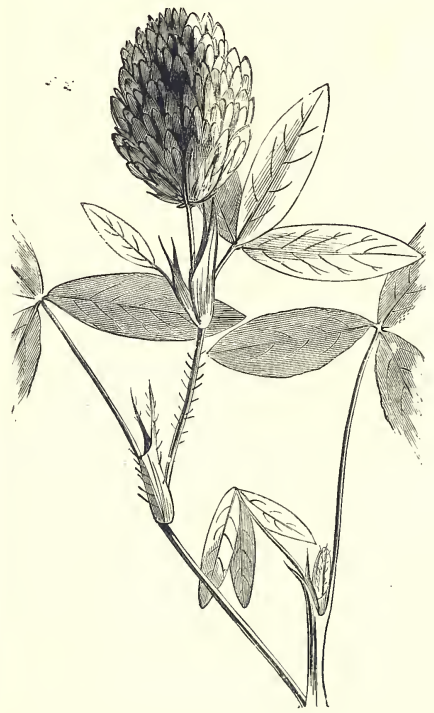

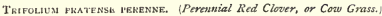




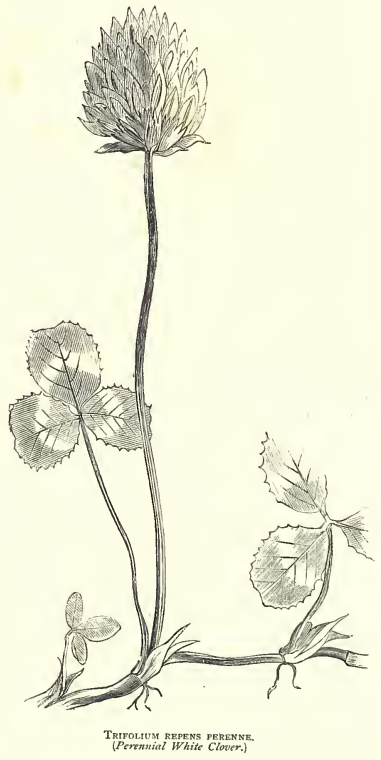




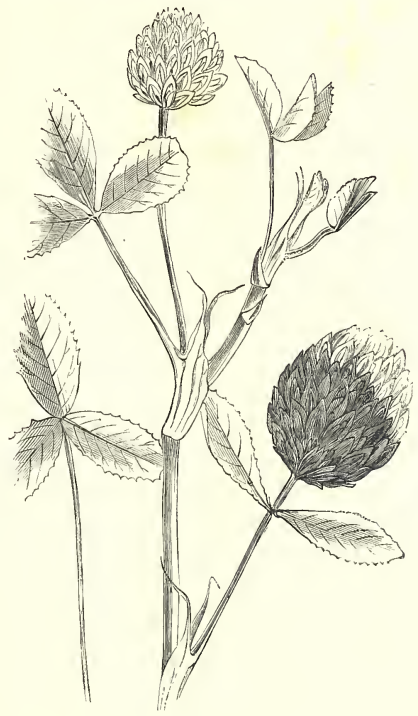

Trifolum hyaktdus.

(Alsike Clower.) 


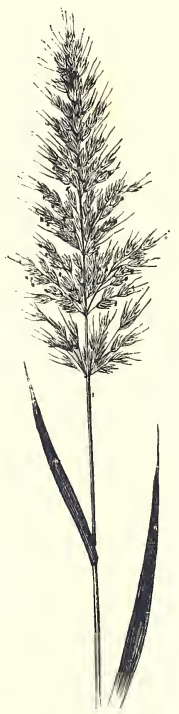

ArRnA FlavesCENS,

(Yellowe Oat Grass.) 


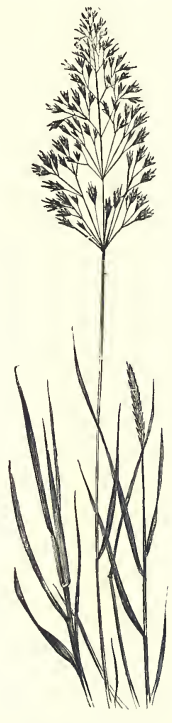

AGROSTIS STOLONIFERA

(Creiting Fiorin, or Marsh Bent Grass.) 


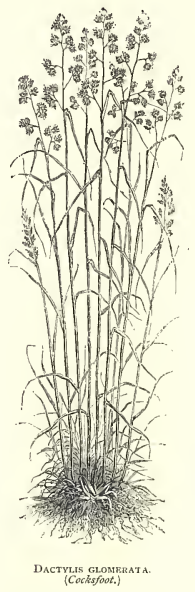




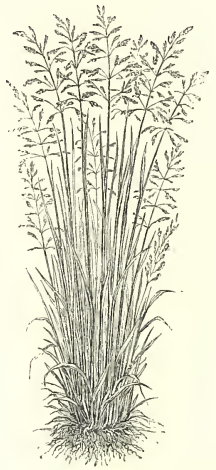

POA PRATrRsis,

Smovth-Stalked Meadow Grass.? 


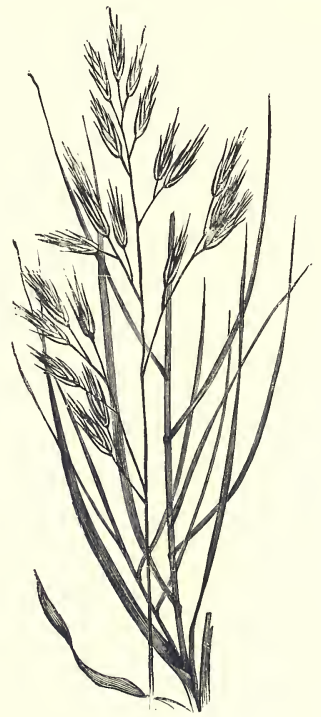

Festuca duriuscut.a.

$$
\begin{aligned}
& \text { (Hard Fescre.) } \\
& \text { (Hard }
\end{aligned}
$$




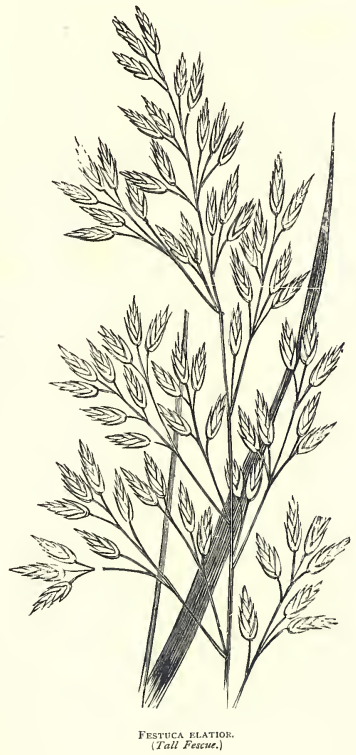




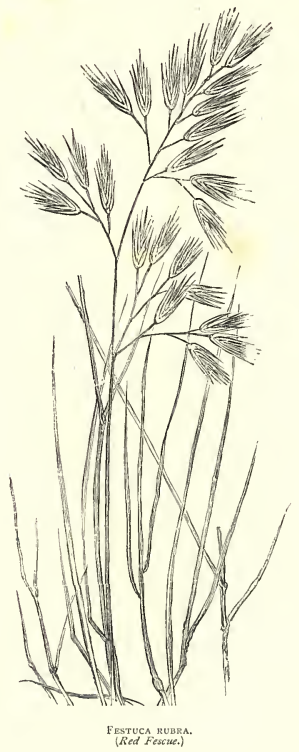




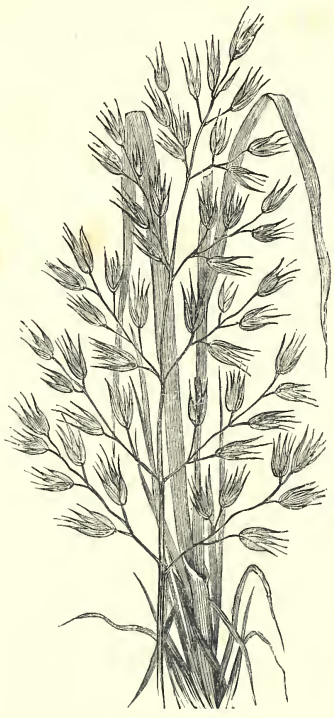

Festuca heterophyli.

(Varions-leaved Fescue.) 


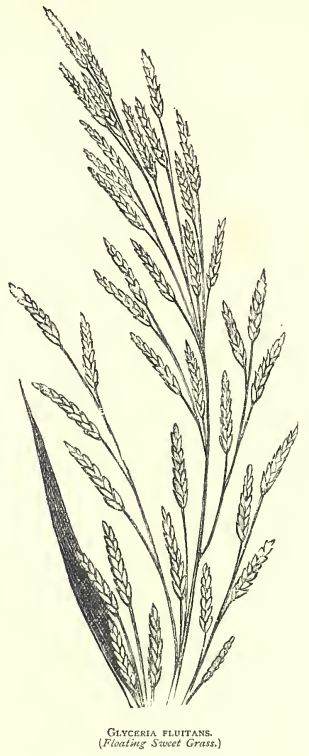




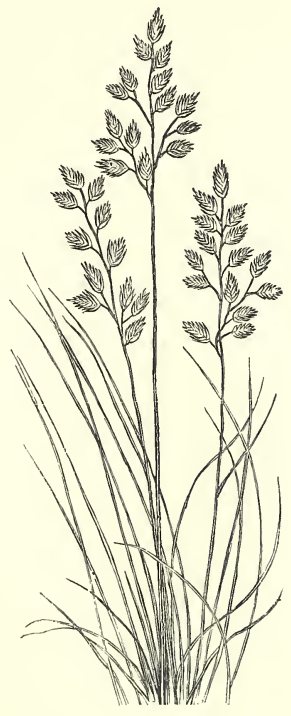

Frstuca tenuirolin. 


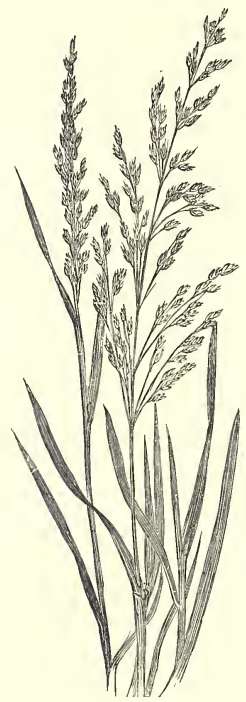

POA NEMORalis.

(Wood Meadow Grass.) 


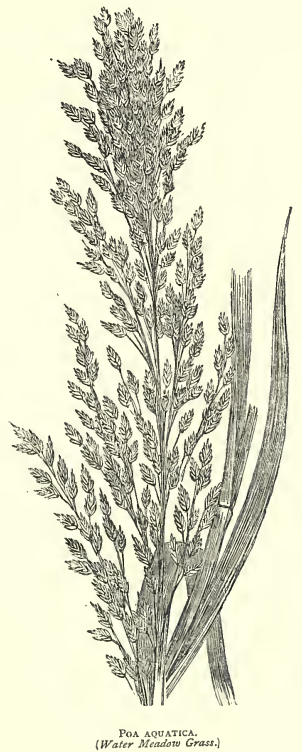




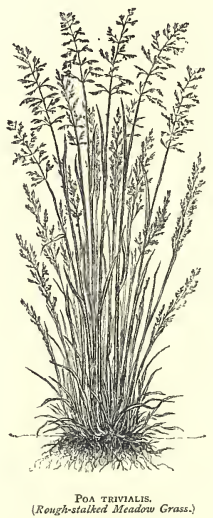




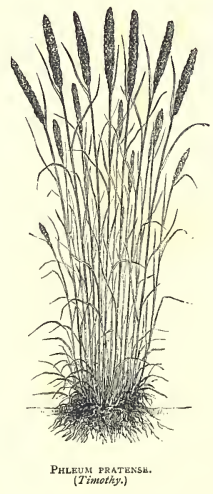


CHAPTER 11 .

The Conversion of Arable Land into Pasture-Preparation of the Land -Sowing the Seeds-Difference in the weight of Grass-seeds-Time of Sowing-Spring Sowing--Laying down Turf by Transplantation -Improvement of the quality of Grass-land.

The Conversion of Arable LAND into PASture. - Land intended to be laid down in grass should be made as perfect as possible, and in as good condition to fit it for the reception of the seed as can be effected by previous tillage and manure; the latter consisting of farmyard dung, ashes, clay, sand, lime, chalk, or marl, according to its condition and requirements. Complete summer fallowing is often recommended, and it should be drained if it requires draining, or even pared and burned; a description of the methods of performing which will be found in the following pages. All root-weeds should be carefully extirpated.

Preparation of the land.-The land should not only be well cleaned and pulverised, but the ridges should be levelled, and the furrows filled in, so as to have a smooth and even surface, which should be finely harrowed, and got in readiness for the reception of the seed. A dry day should be chosen for sowing, and also a still one, for grass seeds should never be sown either in windy weather, or when the surface is wet, which would cause it to become poached.

Sowing the Seeds.-Grass seed is sometimes sown in drills, but as the spaces are left void between the 
rows, where an experienced and good hand can be obtained, it is considered the better plan to sow them broadcast. As the seeds also differ very materially in weight, where several sorts are employed, it is recommended that the light ones be separated from those that are heavy, and each sown separately, for though there will be more trouble incurred in doing this, there will be no comparison in the more equal distribution of the seed, and the going several times over the ground will be recompensed by an equally sown area.

After the seed has been distributed on the surface, it should then be well covered in with light harrows having closely set teeth, or tines. If the soil is porous or spongy, it should be afterwards lightly rolled, or if it is light and clotty, a rolling before the seeds are sown will be found advantageous. On strong land rolling is not considered necessary. As it is desirable to avoid the trampling of horses as much as possible after the seed is sown, and to do away with the effects of their footmarks, in some cases it is desirable to cover the seed by using large hand rakes instead of harrows, and dispense entirely with the latter.

Difference in the weight of Grass-seeds. - With respect to the great difference in the weight of grassseeds, it may be worth while to mention that, while most of the clovers weigh over 6olbs. per imperial bushel, and rib-grass is about 5olbs., meadow cat'stail is 4 olbs.; rye grass in different varieties from 16 to zolbs., most of the poa and fescue tribes are under I 5 lbs., and some of the other grasses even under Iolbs. per bushel.

Time of Sowing.-Sowing is best done in the early 
part of autumn, and not in the spring, according to some, who prefer the close of July for the operation; but if the land can be got into proper order in time, there is nothing to prevent the sowing being done in spring. In autumn sowing, if there follows a severe winter, it is probable that some of the plants will fail, so that it often becomes desirable to sow a small additional quantity in February, or not later than the first fortnight in March, and roll the land well down, for the roots of those already sown may have become loosened by the winter's frost. This will also be the proper time to apply a top-dressing of farmyard manure, which will give strength and nourishment to the roots of the springing crop. Either a well-made compost, or some good rotten farmyard manure are well fitted for this purpose.

Spring Sowing.-If the sowing is done in the spring, and the land has not been previously prepared by a turnip fallow, the well-rotted farmyard manure should be laid on the land before the seeds are put into the ground. If corn is sown at the same time, it should not be too thickly planted, and hand-weeding should be thoroughly performed. When oats or barley are sown with the grass-seeds, the latter is to be preferred to oats, as it possesses a greater tendency to loosen the ground, and so causes the soil to be more favourable to the progress of the grass-seeds, while the crop being reaped earlier, the springing grass will derive greater benefit from the sun.

The seeds have to be chosen with due regard to the nature of the soil, and having given such complete lists already of the grasses best suited to each geological formation, further reference to them is scarcely 
necessary, but it may be roughly stated in addition, that sandy soils are best suited to crested dog's tail, sheep's fescue, hard and smooth fescue, smooth-stalked and meadow soft-grass, oat-like soft-grass, \&c.

Argillaceous soils are favourable to meadow cat's tail, or Timothy grass, meadow fox-tail, tall and meadow fescue, cock's foot, sweet-scented vernal and perennial rye grass.

Calcareous soils develop white clover, rough cock'sfoot, upright perennial brome, meadow hard and sheep's fescue, perennial rye-grass, rib-grass, burnet, yarrow, yellow oat, and sweet-scented vernal grass.

Peaty soils favour meadow soft grass, rough cock's foot, sweet-scented vernal grass, meadow fox-tail, meadow cat's tail, crested dog's tail, and creeping bent.

Fenny soils are adapted for creeping bent, flote fox-tail, flote fescue, water hair-grass, and water poa or reed meadow grass, and other aquatic grasses.

There are other means, however, of laying down grass besides sowing the seeds of grasses, as by laying down turf, the whole surface not needing to be covered.

Laying down Turf by Transplantation.-In some of our colonies, as New Zealand, a capital plan of laying down turf is pursued, by placing it in strips at certain distances from each other, leaving a space between uncovered. In course of time the roots get extended, and the whole becomes one unbroken sward. The idea, however, was not originally a colonial one, but was first practised between sixty and seventy years ago, by a Mr. John Blomfield of Warham, a tenant of the celebrated Mr. Coke of Norfolk. The method has been described by $\mathrm{Mr}$. Blaike in his work on The 
Conversion of Arable Land into Pasture. Operations are commenced in autumn, as soon as the turf, intended to be removed, is sufficiently moistened by the rains to allow it to be pared off clean, and without injury to the plants, or as soon as the farmer can spare his teams and labourers after harvest, and set them about the operation.

A clean, sweet old turf is then chosen of the best description, and cut with the common breast-plough, or with any of the implements that are used in the practice of paring and burning, into strips about two inches and a-half in thickness. Sometimes these are also cross-cut with a heavily-weighted scarifier, so as to press the tines to a proper depth into the earth ; or they are carried to the field intended to be laid down in large flags, then set at straight lines of regular distances, and chopped into pieces about three inches square, as follows:-

A harrow or a scarifier, with round or square tines, about an inch and a-half in diameter, and set about seven inches and a-half apart, or four tines to the yard, is first drawn regularly over the field at right angles; then marking out the distances for placing the pieces of turf, and making an opening for their reception at those angles where the tracks of the tines cross each other. Women and children are then employed to place the pieces with the grass side uppermost, and as they plant each separate piece they press it into the ground with their feet, or, if any difficulty should occur through the hardness of the ground, a common wooden hand-rammer should be used. Particular attention is, however, requisite to this part of the process, for if the roots of the plants are left exposed 
to the weather, they will be materially injured. The whole process should therefore be executed as quickly as possible, especially when it is done towards winter, for as frosts may occur at any time during that season, no more turf should be cut, carried, and spread in the day, than is likely to be laid before night; and no greater extent should at any time be undertaken than there is a probability of completing perfectly.

An acre of old turf, thus divided into squares of three inches, will plant nine acres of arable land, so that one acre cut into pieces of three inches square will produce 696,960 plants. One acre of arable marked out in squares of nine inches to the side of the square, or eighty-one square inches, and one plant to each square, will require 77,440 plants, each standing six inches apart, and occupying nine square inches of space. One acre of turf to six of arable is, however, a surer proportion.

Although this is the most common, and generally considered the most proper size for the pieces, and the distance for their being set apart, yet if not convenient to spare so much old sward, they may with safety be placed much wider. It is also evident that no part of the old meadow need be wholly destroyed, as narrow strips of turf may be cut from it at such moderate distances as will ensure the blank spaces being afterwards filled up with a fresh growth. It has, indeed, been found to improve rather than to injure sward which was previously hide-bound, or mossed, in the same manner it would as if scarified: it should, however, have a good top-dressing, be replenished with the seeds of those grasses in which it may be deficient, and be well rolled. 
$\mathrm{Mr}$. Coke, upon one occasion, offered a premium for the encouragement of this method of laying down pasture-land, and the expense of the process of converting arable-land into pasture after this system, was stated by one of the claimants to be about $£^{2} 9$ s. $3 d$. per acre, according to the following calculations :

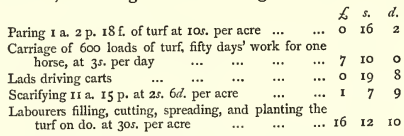

In this calculation it will be observed that, there is no allowance made for the years' rent and taxes, or for the expenses incurred in the previous summer fallow of the arable land, nor any charge mentioned for restoration of the land from whence the turf was taken, so that the real cost would amount to considerably more.

Poor grass land already established may be much improved in quality.

Improvement of the quality of Grass-land.-There are two methods which are usually followed for the improvement of the quality of indifferent grass-land, by simply harrowing in grass-seed at the proper season, or by mixing the seeds with a top-dressing of compost, which ought not to be less than at the rate of ten cubic yards per acre. The last method takes the smallest quantity of seeds, and they will be most productive during the first year, but the expense will be greater than the first-named method, which, however, enables a greater extent of pasture to be sown at a much smaller cost. 
When the grass-seeds are sown in conjunction with a top-dressing, the materials of which the compost consists should as much as possible be of that nature, that when applied will improve the quality of the surface of the soil, as well as enriching it, which will be obtained by causing it to consist of one half spit dung, and the other half made up of light sandy earth, road-scrapings, coal and wood ashes, dry pond-mud that has been previously mixed with hot lime, and the scourings of ditches; the hot lime being only used to the pond-mud and the latter, to excite their action and get them into a proper condition to be applied to the land. This compost should be turned over frequently, and well incorporated during the course of several months, and be got into a workable condition, best fitted for its application in the medium form between dryness and moisture, which causes it to crumble freely under the action of the spade, which will allow of its being easily mixed with the grass-seeds. This should, however, not be done until the day before it is intended to use the seeds. The seeds and the compost are best mixed by passing them at the same time through a coarse wire sieve, and after they have had a little practice, a couple of men can prepare a large quantity in the course of one day.

The sward to which the seed and top-dressing is about to be applied, should be well harrowed or scarified, so as to enable the top-dressing to come into immediate contact with the soil, and this so far from injuring the old turf, will be found to greatly benefit it. Unless the land happen to be very light, rolling is not required, but on the contrary if the land is in a damp condition may even do it harm. If this operation 
is attempted to be done with the view of ultimately laying up the pasture for hay in the same year, the older grasses will probably overpower the seedlings, or at all events greatly injure their growth and progress, and it is therefore found better when this operation is performed, to pasture with young cattle stock, but not put sheep in it (which bite close), during the first year, and the best time for doing the job is in March, or early April.

When seeds are merely sown, the surface must be well scarified, and it is quite essential that the land is well-drained, and all surface-water carried off. Surface draining, as described in another place, is very easily done. It is necessary also to use a larger quantity of seed in this case than in the other, as the vegetative powers of the seeds are naturally much assisted by the top-dressing.

As only certain grasses will do well upon certain soils, it is highly necessary that this point should be first ascertained, and for this I must refer the reader to Messrs. Sutton's capital tables which specify the particular grasses best suited to each geological formation, by which everyone can be guided each in his own particular case, and select appropriate seeds. 


\section{CHAPTER IV.}

Action of Manures and the Atmosphere upon Grass-land-The Meadows of Holland - Nitrogen in Manures - Boussingault's Opinions-Liebig's Deductions-Analyses of different Plants-Bonssingault's Farm in Alsace-Meadow and Arable Land compared for Carbon and Nitrogen-Application of Manure to Meadow and Arable Land-Rotation of Crops in Alsace-Rotation of Crops in Bingen-Boussingault's Investigations-Dried Human Excrements -Dried Excrements in Egypt forming Sal-Ammoniac-Fields in the valley of the Nile-Nitrogen found in crops not in proportion to that supplied in manure-The formation of Nitrogen depends upon the presence of certain substances contained in the Soil-Supplying Ammonia sometimes superfluons-Successful Farming ensured by the Application of Scientific Principles.

ACTION OF MANURES AND THE ATMOSPHERE UPON GRASS-LAND.-It is unfortunately commonly assumed by those who do not possess any knowledge of agricultural chemistry, that grass-land is much the same, so far as the operation of the growth of the crop is concerned, in its effects as respects the exhaustion of the soil, as the results of any given crop grown upon arable land, only not to so great a degree, and requires precisely the same treatment on the same geological formation. The cases, however, are widely divergent, and although there can be no better manure for grassland than well decomposed farmyard manure, which is the best perhaps, also for arable land save under exceptional conditions, it is not so with many kinds of manures, which may be profitably and advantageously employed elsewhere, when there happens to be a dearth of certain constituents in the soil. 
Where farmyard manure is not to be obtained in sufficient quantity, guano, superphosphate, or partiallydissolved bones with a small addition of salt or nitrate of soda, forms an excellent manure, but the latter if used alone, the same as applied when required at times for arable land, instead of developing the bottom herbage, in the form of clover and other desirable growths, would stimulate cocksfoot, and such like luxuriant-growing grasses, to the detriment of the finer kinds. This is the tendency of ammoniacal salts, while superphosphate of lime encourages the growth of clovers and leguminous plants, the latter acting as fixers of certain properties derived from the atmosphere, which other crops have not the same power of assimilating, and this action I will briefly explain.

The knowledge of the processes of nutrition, says Liebig, in the case of the culture of meadow land, indicates that the atmosphere contains an inexhaustible quantity of carbonic acid. On equal surface of wood or of meadow-land, in which exist the constituents of the soil indispensable to vegetation, we obtain crops without the aid of carbonaceous manures; and these crops contain, in the form of wood and hay, a quantity of carbon equal to, or in many cases greater than, that produced by cultivated land in the form of straw, corn, and roots.

It is obvious that the cultivated land must have presented to it as much carbonic acid as is furnished to an equal surface of wood, or of meadow land; that the carbon of this carbonic acid becomes assimilated, or is capable of assimilation, if the conditions exist for its reception and conversion into a constituent of plants. 
The crop of a meadow, or of an equal surface of woodland, is quite independent of carbonaceous manures, as far as regards its carbon, and also on the conditions which enable these to enter into the plants. Now we are able to increase the crop of carbon on our cultivated land by the use of burnt-lime ashes or marl,-by substances, therefore, which are entirely free from carbon. This well-ascertained fact indicates that we furnish to the field in these substances, certain constituents which enable the cultivated plants to increase in mass, and consequently in carbon-a power which they possessed formerly only in a small degree.

After these considerations, it cannot be denied that the sterility of a field, or its poverty of produce in carbon, does not arise from a deficiency of carbonic acid or of humus; for we have seen that this produce can be increased to a certain extent by the supply of matters destitute of carbon. But the very same source which supplies the meadow and the woodland with carbon, namely, the atmosphere, can yield that element to cultivated plants. It therefore becomes especially necessary in agriculture to employ the best and most convenient means of enabling the carbon of the atmosphere (carbonic acid) to pass over into the plants growing in our fields. The art of agriculture in the mineral food which it supplies, furnishes to plants the means of appropriating their carbon from sources offering an inexhaustible provision. But when these constituents of the soil are wanting the most abundant supply of carbonic acid, or of decaying vegetable matter, cannot increase the crops in the field. 
Upon a Hessian acre of good meadow land we obtain $2500 \mathrm{lbs}$. of hay, according to the opinion of experienced farmers. Meadows yield this crop without any supply of organic matters, or without any manures containing nitrogen or carbon. By proper irrigation, and by treatment with ashes and gypsum, the crop can be increased to double the amount. Let us assume, however, that the $2500 \mathrm{lbs}$. of hay form the maximum crop; still it is certain that all the carbon and nitrogen of the plants constituting it must have been obtained from the air.

All plants of the grass kind require silicate of potash. Now this is conveyed to the soil, or rendered soluble in it, by the irrigation of meadows. The equisetacee, the reeds and species of cane containing such large quantities of siliceous earth, or silicate of potash, thrive luxuriantly in marshes, in argillaceous soils rich in potash, and in ditches and streamlets, where the change of water renews constantly the supply of dissolved silica. The amount of silicate of potash removed from a meadow in the form of hay is very considerable. We need only call to mind the melted vitreous mass found on a meadow between Manheim and Heidelberg after a thunderstorm. This mass was at first supposed to be a meteor, but was found on examination (by Gmelin) to consist of silicate of potash; a flash of lightning had struck a stack of hay, and nothing was found in its place except the melted ashes of the hay.

This incident, which Liebig quotes, afforded a lively illustration of the opportunity for the crossexamination of nature, so to speak, which is elicited by tracing the constituent properties of plants through 
an analysis of their ashes, and the working of the principle to which I have referred, is explained by his references to the meadows of Holland.

The Meadozus of Holland.-Cheese must be formed from the plants upon which cows feed. The meadows of Holland must, of course, obtain their nitrogen from the air. The milch-cows in Holland remain on the fields both day and night ; and the salts contained in their fodder must remain upon the fields in the form of urine and of solid excrements, a small quantity proportionally being removed in the cheese.

The condition of fertility of these meadows can change as little as that of our fields, which, although not grazed upon, receive in the form of manure the greatest part of the ingredients removed from them.

In the cheese districts of Holland, these ingredients remain on the meadows; while in our system of farming they are collected at home, and carried from time to time to our fields. The nitrogen of the urine, and that of the solid excrements of the cow, are obtained in Holland from the air, and from the same source must be obtained the quantity of that element contained in all the kinds of cheese prepared in Holland, Switzerland, and other countries.

The meadows of Holland for centuries have produced millions of cwts. of cheese; there are annually exported from that country thousands of cwts. of this substance; and yet this exportation does not in any way diminish the productiveness of their meadows, although they have never received from the hand of man more nitrogen than they originally contained.

Nitrogen in Manures.-Liebig comments at length upon what he considers the erroneous view of 
estimating the value of manure, usually adopted in France and Holland, according to the amount of its nitrogen.

Boussingault, who tried a great number of interesting experiments, adopts this view, which certain English authors have also adopted; but Liebig says, "The conclusions of Boussingault are not only erroneous in their application to agriculture, but are incorrect in the methods which he employs, for the manure was not given to the fields in the form in which he analysed it."

Boussingault's Opinion.-Boussingault concluded that leguminous plants (peas, beans, \&c.) alone possess the power of appropriating, as food, nitrogen from the air; and that other cultivated plants do not at all possess this property. Hence the great importance he ascribes to manures containing nitrogen, which according to his view depends for its commercial value upon its amount of nitrogen. But these conclusions Liebig declares to be thoroughly incorrect, for if they were not so, it must follow that potash, lime, and silica plants, unless they belonged to the Leguminosæ, would not produce any nitrogen unless they were supplied with manure containing that element.

As the correct deduction to be derived from the results of Boussingault's experiments is a very important matter-for the effect of certain manures and the right appreciation of their operation and working hangs upon it by those who have been guided by his conclusions - I give Liebig's deductions, though for convenience sake, not always in the order in which he expressed them. 
Liebig's Deductions.-For every 100 parts of carbonic acid absorbed by the surface of the leaves of the meadow plants, there must also be absorbed from the air above one part of ammonia. When we calculate how much nitrogen different plants obtain from equal surfaces of land, being our calculation upon known analyses, the following results are obtained :-

Analyses of Different Plants.-1000 parts of carbon removed in nitrogen.

\begin{tabular}{|c|c|c|c|c|c|c|}
\hline \multicolumn{7}{|c|}{ From meadow land in hay ... } \\
\hline " & arable land, & in wheat & $\ldots$ & $\cdots$ & $\cdots$ & $2 I \cdot 5$ \\
\hline , &, & in oats & $\ldots$ & $\ldots$ & .. & $22 \cdot 3$ \\
\hline ", & ," & in rye & $\cdots$ & $\ldots$ & $\cdots$ & $15^{\prime 2}$ \\
\hline ", &, & in potato & & $\ldots$ & $\ldots$ & $34^{-1}$ \\
\hline , & ", & in mange & l wurze & & ... & $39^{*} \mathrm{I}$ \\
\hline , & $"$ & in clover & & $\ldots$ & $\ldots$ & $44^{\circ} \mathrm{O}$ \\
\hline " & ," & in peas & $\ldots$ & $\ldots$ & $\ldots$ & $62 \%$ \\
\hline
\end{tabular}

These facts lead to certain conclusions of high importance to agriculture. We observe, in fact, that the proportion of nitrogen absorbed, relatively to that of carbon, stands in a fixed relation to the surface of the leaves.

I. Plants CONTAining NEARLY ALL THEIR NITROGEN CONCENTRATED IN THEIR SEEDS, SUCH AS THE CEREALS, CONTAIN ALTOGETHER LESS NITROGEN THAN THE LEGUMINOUS PLANTS, PEAS AND CLOVER.

2. THE CROP OF NITROGEN FROM A MEADOW TO WHICH NO AZOTISED MANURE HAS BEEN GIVEN IS MUCH GREATER THAN THAT FROM A MANURED FIELD OF WHEAT.

3. THE CROP OF NITROGEN IN CLOVER OR IN PEAS IS MUCH GREATER THAN THAT IN A HIGHLY MANURED FIELD OF POTATOES OR OF TURNIPS. 
Boussingault's Farm in Alsace.-Boussingault obtained, in five years, from his farm in Bechelbronn, Alsace, in the form of potatoes, wheat, clover, turnips, and oats, 8383 carbon, and 250.7 nitrogen; in the succeeding five years (beet, wheat, clover, wheat, late turnips, oats, rye), 8192 carbon, $284^{\circ} 2$ nitrogen; in a third rotation of six years (potatoes, wheat, clover, wheat, late turnips, peas, rye), I0949 carbon, 353.6 nitrogen; OR ALTOGETHER IN THE PROPORTION OF IOOO CARBON TO 3I'3 NITROGEN.

A most remarkable and important result follows from this experiment-that when potatoes, wheat, turnips, peas, and clover (PoTASH, LIME, AND SILICA PLANTS), are cultivated successively on the same field, although this field had been thrice manured in the course of sixteen years, the same relation of nitrogen to a given quantity of carbon is obtained as in the case of a meadow which had received no manure.

Mcadow and arable land compared for Carbon and Nitrogen:-

Upon an acre of meadow land there is cropped of silica, lime, and potash plants, taken together

Carbon. Nitrogen.

$984^{\circ} \quad 32^{*} 2$

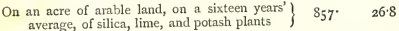

When we take into consideration the amount of carbon and nitrogen in the leaves of the beet and potato (for the leaves were not calculated in the produce of the arable land), then it follows that, notwithstanding all the supply of carbon and of nitrogen furnished in the manure, the arable land has not produced more of these elements than an equal surface of meadow land, WHICH RECEIVED ONLY MINERAL FOOD (constituents of the soil). 
THEN-ON WHAT DEPENDS THE PECULIAR ACTION OF MANURES, AND OF THE LIQUID AND SOLID EXCREMENTS OF ANIMALS?

This question is susceptible of a simple solution. These manures have a very decided action on our arable land, from which for centuries we have removed, in the form of cattle and of corn, a certain quantity of constituents of the soil which have not been restored.

If no manure had been applied to the land during the sixteen years of the above experiment, the crop would have amounted to only a half, or third part of the carbon and nitrogen.

The liquid and solid excrements used as manure, enabled this surface of arable land to produce as much as the meadow land. But notwithstanding the amount of manure supplied, the field was no richer in the mineral food of plants on the sixth year, when it was manured anew, than it was in the first year. In the second year after manuring it contained less mineral food than on the first year; and after the fifth year it became so much exhausted that it was necessary, in order to obtain crops as rich as the first year, to give back to the field all the mineral constituents that had been removed during the five years' rotation; this was done, without doubt, by means of the manure.

Application of Manure to Meadow and Arable Land. -Our supply of manure, therefore, effects only this result, that the soil of our arable land is not rendered poorer than that of meadow land capable of yielding on the same surface $25 \mathrm{cwt}$. of hay. From a meadow we remove annually, in the hay, as great an amount of the constituents of the soil as we do in the crops obtained from the arable land; and we know that the fertility 
of meadow land is as dependant on the restoration of the constituents of the soil as that of arable land is upon the supply of manure. Two meadows of equal surfaces, but containing unequal quantities of inorganic food, are of unequal fertility under like circumstances. The meadow containing the greatest quantity of the mineral food yields more hay, in a certain number of years, than the other which is poorer in mineral ingredients.

But if we do not restore to a meadow the constituents of the soil removed from it, its fertility decreases.

The fertility of a meadow remains the same, not only by treating it with solid or with liquid excrements, but it may be retained, or may be even increased in fertility by the application of mineral substances left behind after the combination of wood, or of other plants. By means of AsHes we can restore the impaired fertility of our meadow land. But by the term AsHes, we understand the mineral food which plants received from the soil. When we furnish them to our meadows we enable the plants growing on them to condense carbon and nitrogen on their surface. Now, does not the action of liquid and solid excrements depend on the same cause? FOR THESE ARE BUT THE ASHES OF PLANTS BURNT IN THE BODIES OF MAN AND OF OTHER ANIMALS. Is fertility not quite independent of the ammonia conveyed to the soil? If we evaporated urine, dried and burned the solid excrements, and supplied to our land the salts of the urine, and the ashes of the solid excrements, would not the cultivated plants growing on it-the gramineæ and leguminosæ-obtain their carbon and nitrogen 
from the same sources whence they are obtained by the graminex and leguminosæ of our meadows?

There can scarcely be a doubt with regard to these questions, when we unite the information furnished by science to that supplied by the practice of agriculture.

Rotation of Crops in Alsace.-The following rotation is adopted in Alsace, as being the most advantageous; it extends over a period of five years, during which the land is only once manured:-

\begin{tabular}{|c|c|c|c|c|c|}
\hline $\begin{array}{l}\text { Ist year. } \\
\text { Manured. }\end{array}$ & 2nd year. & nd year. & $4^{\text {th }}$ year. & year. & $\begin{array}{l}\text { 6th year. } \\
\text { Manurd. }\end{array}$ \\
\hline $\begin{array}{l}\text { Potatoes } \\
\text { or Beet. }\end{array}$ & Wheat. & Clover. & $\begin{array}{l}\text { Wheat with } \\
\text { Fallow, Turnips. }\end{array}$ & $\begin{array}{l}\text { Oats, or } \\
\text { Rye, or } \\
\text { Barley. }\end{array}$ & \\
\hline & & $\begin{array}{l}\text { Lime } \\
\text { Plant. }\end{array}$ & $\left.\begin{array}{l}\text { Silich, } \\
\text { Potash }\end{array}\right\}$ Plants. & $\left.\begin{array}{c}\text { SILICA, } \\
\text { LIME }\end{array}\right\}$ & Plant \\
\hline
\end{tabular}

Now, if we suppose that the action of the manure depends upon its ammonia, or amount of nitrogen, then it is obvious that a progressive diminution must ensue; that the nitrogen in the crops of the first and second years must amount to more than that contained in the crops of the fourth and fifth years. But this opinion is completely opposed to the following proportions, as indicated by analysis:-

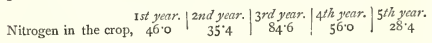

Thus in the third and fourth years, the nitrogen in the crops amounted to much more than the quantity contained in the crops of the first and second years; and in the fifth year, the quantity was only one-fourth less than it was in the second year. Now is it possible or conceivable that the ammonia given in the first year, being a body of great volatility and very apt to evaporate along with water, could be present in greater 
quantity in the soil during the fourth year than it was in the first and second years, or that it could yield to the oats of the fifth year the necessary quantity of nitrogen for their growth?

But let us admit that the nitrogen conveyed to the soil by strong manuring was actually exhausted in the fifth year by the different plants cultivated upon it, and let us then compare the rotation employed in Alsace with that adopted on one of the most fertile districts of the Rhine.

Rotation of Crops in Bingen.-In Bingen there is a nine years rotation followed, the plants succeeding each other in the following order:-

\begin{tabular}{c|c|c|c|c|c}
$\begin{array}{c}\text { Ist year. } \\
\text { Manured. } \\
\text { Turnips. }\end{array}$ & $\begin{array}{c}2 n d \text { year. } \\
\text { Barley with } \\
\text { Lucern. }\end{array}$ & Lucern. & Potatoes. & Wheat. & $\begin{array}{c}\text { Mth year } \\
\text { Manted }\end{array}$ \\
Barley.
\end{tabular}

Six years after manuring, after the supply of ammonia and manure containing nitrogen, after four succeeding crops of clover, and after a crop of barley and one of oats, the soil of Bingen yields rich crops of potatoes, wheat, and barley, and these succeed each other at a time when, according to our assumption, the manured field in Alsace was to be viewed as completely exhausted of its nitrogen. Can it be conceived that the ammonia of the manure could, after the lapse of $8-9$ years, furnish the nitrogen to the crops of wheat and barley? But even admitting this to be the case, we have then to inquire, Whence do the cornfields in Hungary, Sicily, or in the vicinity of Naples, receive their nitrogen ? for these fields have never been manured. Are we actually to believe that the nutrition of plants in the fields of moderate climates are 
subject to different laws from those governing the warmer and tropical regions?

This nitrogen is not contained in the soil, nor is it conveyed to the wild plants by the hand of man. Then it is impossible to doubt the source whence the nitrogen is obtained. The source of the nitrogen can only be the atmosphere. It matters not in what form it is contained therein, or in what form it is taken from it ; the conclusion is the same, that the nitrogen of wild-growing plants must be derived from the atmosphere.

Boussingault's Investigations.-These questions are completely solved by the investigations of Boussingault, which are so much the more valuable as they were instituted with a totally distinct object in view.

From the known quantity of manure (common stable manure) which Boussingault put every five years upon his field (amounting to four Hessian acres), he estimated, by the analysis of the manure, the total quantity of nitrogen furnished for the rotation of five years. For this purpose the moist stable manure was first dried by exposure to the air and to the sun, and afterwards was further dried in vacuo, by exposing it to a temperature of $230^{\circ} \mathrm{F}$; ; the manure thus treated was subjected to an ultimate analysis. The average crops of the field, treated with manure, were then determined, and the products, corn and straw, turnips, potatoes, peas, clover, \&c., were analysed for the purpose of ascertaining their composition with reference to nitrogen, carbon, hydrogen, and ashes.

In this manner the quantities of nitrogen conveyed to the field in the form of manure, and reaped from it in the crops, were ascertained, and could be compared 
together. If the plants depended for their nitrogen upon the manure, and did not receive any of that element from the air, the nitrogen of the crops could not correspond to more than the quantity in the manure. If the crops contained more than this quantity, the excess must have been obtained from other sources, and these could only be in the atmosphere. Such were the suppositions on which Boussingault proceeded. According to his estimation the three rotations yielded-

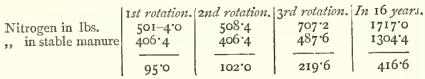

In the first and second rotation the excess of nitrogen obtained was nearly equal; in the third it was twice as much.

Now, asked Boussingault, Did each of these plants possess the power of absorbing and appropriating to their organism nitrogen from the air, or was this power confined only to one of them; and was the excess of nitrogen due to all the various kinds of plants, or was it yielded by only one of them? A new experiment seemed to him to decide the question. Two successive crops of corn were taken from a fallow field, well manured, and the produce amounted to-

$\begin{array}{cccc}\text { Nitrogen in the crops } & \ldots & \ldots & 174.8 \mathrm{lbs} . \\ , ", \text { manure } & \ldots & \ldots & 165.6 \\ \text { An excess of nitrogen } & \ldots & \ldots & 9.2 \\ \text { Ibs. }\end{array}$

But this excess in the crop is too small not to be liable to errors in the experiment. Boussingault concluded from it that cereals do not absorb nitrogen 
from the air, and that the amount of nitrogen yielded in crops is only equivalent to that contained in the manures.

Now, as it had been found that the quantity of nitrogen obtained in crops of potatoes and turnips scarcely corresponds to more than the quantity in crops of wheat, it follows that they could not have the power to form their azotised constituents without: manure; so that nothing remains except to ascribe to the clover the excess of nitrogen obtained. This explains, also, why the excess is so much greater in the third rotation than in any of the preceding ; for it will be remarked, that in the third rotation a sixth crop was introduced, corresponding to the same family as clover. If, therefore, there had been neither peas nor clover in the third rotation, but instead of these plants, one of another family, the nitrogen of the crop would have amounted only to the quantity supplied in the manure. In thus checking, as it were, Boussingault's experiments, and the conclusions he arrived at, which Liebig declares to be erroneous, on the ground that the former was incorrect in the method employed, for the manure was not given to the fields in the form in which he analysed it, he goes on to say, Let us assume that the manure which he put upon his fields possessed the same state in which it was analysed (dried at $230 \mathrm{~F}$.; in vacuo); then the fields would receive in the sixteen years $1300 \mathrm{lbs}$. of nitrogen. But the manure was not put upon the fields in an antrydrous state, but, on the contrary, in its natural moist condition, soaked with water; and we know that all the nitrogen contained in the manure in the form of carbonate of ammonia is volatised when it is 
dried at a high temperature. The nitrogen of the urine in the manure, which is converted by putrefaction into carbonate of ammonia, is not included in the 1300 lbs. of the above calculation.

Dried Human Excrements.-Human excrements, dried in the air at ordinary temperatures (poudrette), lose at $230^{\circ}$ half of all the nitrogen contained in them, in the form of carbonate of ammonia. Common stable manure, which contains 79-80 per cent. of water, must lose, when heated to $230^{\circ}$ in vacuo, at least three times as much nitrogen as it retains; that is, $3-4$ ths of all the nitrogen originally present in it. But if we estimate it at half of the quantity present in the dried excrements, then the field must have received, in 16 years, I950 lbs. of nitrogen.

BOUSSINGAULT'S ERRONEOUS CONCLUSION AS TO

LEGUMINOSE ALONE POSSESSING THE POWER OF CONDENSING NITROGEN.

But in 16 years, 1517 lbs. of nitrogen only were obtained, in the form of corn, straw, and tubers; much less, therefore, than the quantity furnished to the field. Hence his erroneous conclusion, that the Leguminosx alone possess the power of condensing nitrogen from the air; and that it is necessary to furnish nitrogen to the Graminex, and to plants such as turnips and potatoes. But in the same time, and upon the same surface of a good meadow, not receiving nitrogen, we may obtain (on I hectare) $2060 \mathrm{lbs}$. of this element.

Dried Excrements in Egypt forming Sal-ammoniac. -It is well known that dried excrements form the principal fuel in Egypt, where wood is scarce. For 
centuries the sal-ammoniac used in Europe was supplied from the soot of these excrements, until Gravenhorst, in the latter part of last century, discovered how to prepare it, and instituted a manufactory at Brunswick.

Fields in the Valley of the Nile.-The fields in the Valley of the Nile receive no manure of animal origin except the fixed ingredients (which contain no nitrogen) of the ashes of the burnt dung; and yet these fields have been so fertile, for periods long before our history commences, that this fertility has become a proverb, and is quite as remarkable in the present day as it was in former times. These fields become renovated by the mud deposited during the inundations of the Nile; the mineral ingredients of the soil removed in the crop are thus restored to it. The mud of the Nile contains as little nitrogen as the mud from the Alps in Switzerland, deposited on, and fertilizing, our own fields by the inundations of the Rhine.

In fact, if the mud of the Nile fertilizes the soil, in consequence of its containing nitrogen, we must suppose immense strata of nitrogenized animal and vegetable matter to exist in the mountains of Africa, at heights above the line of perpetual congelation, where owing to the absence of all vegetation, no animal, not even a bird, can now find nourishment.

Nitrogen found in Crops not in proportion to that supplied in Manure.-Hence it is quite certain, that in our fields the amount of nitrogen in the crops is not at all in proportion to the quantity supplied in the manure, and that the soil cannot be cxhausted by the exportation of products containing nitrogen (unless these products contain at the same time a large amount of mineral ingredients), because the nitrogen 
of vegetation is furnished by the atmosphere, and not by the soil. Hence also we cannot augment the fertility of our fields, or their powers of production, by supplying them with manures rich in nitrogen, or with ammoniacal salts alone. The crops on a field diminish or increase in exact proportion to the diminution or increase of the mineral substances conveyed to it in manure.

THE FORMATION OF NITROGEN DEPENDS UPON THE PRESENCE OF CERTAIN SUBSTANCES CONTAINED IN THE SOIL.

The formation of the vegetable substances containing nitrogen existing in cultivated plants, depends upon the presence of certain substances contained in the soil. When these ingredients are absent, nitrogen will not be assimilated, however abundantly it may be supplied. The ammonia of animal excrements exerts a favourable influence, only because it is accompanied by other substances necessary for its conversion into the constituents of blood. When these conditions are furnished with ammonia, the latter becomes assimilated. But when the ammonia is absent from the manure, the plants extract their nitrogen from the ammonia of the air; to which it is again restored by the decay and putrefaction of dead animal and vegetable remains. Ammonia accelerates and favours the growth of plants in all kinds of soil in which exist the conditions for its assimilation.

By means of ammonia, in the form of animal excrements, we increase the quantity of the constituents of blood in our cultivated plants-an action which the carbonate or sulphate of ammonia alone never exerts. 
Supplying Ammonia sometimes superfutous. - In order to obviate any misunderstanding, I must again draw attention to the fact that this explanation is not in any way contradicted by the effects produced on the application of artificial ammonia, or of its salts. Ammonia is, and will continue to be, the source of all the nitrogen of plants: its supply is never injurious; on the contrary, it is always useful, and for certain purposes indispensable. But at the same time, it is of great importance for agriculture to know with certainty that the supply of ammonia is unnecessary for most of our cultivated plants, and that it may be even superfluous, if only the soil contain a sufficient supply of the mineral food of plants, when the ammonia required for the development will be furnished by the atmosphere. It is also of importance to know, that the rule usually adopted in France and in Germany of estimating the value of a manure according to the amount of its nitrogen, is quite fallacious, and that its value does not stand in proportion to its nitrogen.

Successful Farming ensured by the application of Scientific Principles.-By an exact estimation of the quantity of ashes in cultivated plants, growing on various kinds of soils, and by their analysis, we will learn those constituents of the plants which are variable, and those which remain constant. Thus also we will attain a knowledge of the quantities of all the constituents removed from the soil by different crops.

The farmer will thus be enabled, like a systematic manufacturer, to have a book attached to each field, in which he will note the amount of the various ingredients removed from the land in the form of crops, and therefore how much he must restore to bring it 
to its original state of fertility. He will also be able to express, in pounds weight, how much of one or of another ingredient of soils he must add to his own land in order to increase its fertility for certain kinds of plants.

These investigations are a necessity of the times in which we live; but in a few years, by the united diligence of chemists of all countries, we may expect to see the realization of these views; and by the aid of intelligent farmers, we may confidently expect to see established, on an immovable foundation, a rational system of farming for all countries and for all soils.

I have given Liebig's opinions at length, as the principles enunciated are very important to agriculture, and for the details of these principles I must refer the general reader to his book on The Chenistry of Agriculture, and Physiology; the gist of the whole is, that we are in a position to give to the most sterile soil a state of the greatest fertility for all plants, if we furnish to it the constituents which they require for their growth. And although it would not pay to render fertile on those principles an absolutely sterile soil, on our ordinary arable soils, which contain already many of these constituents, it suffices to supply the absent ingredients, or to increase those which are in deficient quantity. At the same time, by the art of farming, and by complete pulverisation of the soil, it must be put into a proper physical state, by which it is rendered accessible to moisture and to rain, and is fitted to enable the plants to appropriate these ingredients of the soil. 


\section{CHAPTER V. \\ PAKING AND BURNING.}

Pitting-Practice in Northamptonshire-Method in Ireland-General Principles-Method of Paring-Paring and Burning Bogs in Ireland -Favourable Estimation of Mr. Boys-Injurious to Poor Shallow Soils-Beneficial to Fen, Bog, and Morass.

ARTHUR YOUNG said, and the remark has very often been quoted, that it was a laudable thing for a man to make two blades of grass grow where only one used to grow before; a result which, when summed up in the score of profit to the agriculturist, means that he will take two tons of hay off a certain amount of his meadow-land, where he was only accustomed to take one, and this result is to be attained sometimes by paring and burning.

Pitting.-Paring and burning are useful and necessary operations, either in the case of old pastures which have become unproductive, and foul with weeds; upon bog land; or heavy clay land. The operation is one of some little nicety, and requires to be done by an experienced hand; and the system has many opponents as well as many friends; the fac. being that it has sometimes been injudiciously applied to soils that are not suitable for it, and the principles upon which the system rests requires to be understood. There can be no question but that the operation is both a cheap and effectual mode of bringing land into a good state of cultivation that has lain waste, 
and become overgrown with root-weeds, as in the case of worn-out old meadows and turf land, composed mainly of humus or accumulations of organic matter. When, however, in the process of burning upon clay land, the heaps have been allowed to remain too long unspread, the fire has taken hold of the ground, instead of being carefully watched and extinguished in time, so that the spaces which they covered have become converted into brick, and large unsightly holes made in the earth, called "pitting," which retains the wet, and so damages instead of benefiting the land; but care should be taken to guard against such accidents.

But even used as a dressing for heavy land, the process is often a most valuable one, and has been extensively practised in Northamptonshire. In Baker's Report of the Agriculture of Northamptonshire, the process is described of burning the clay and earth to be used as a dressing for land to make it more friable.

Mr. Baker attributes the origin of the practice to Mr. Collins of Monk's Park, near Northampton, but whoever may have introduced it into this part of the country it is one of a very ancient date, and has been in use from time immemorial by our ancestors, and was known to the Romans. In Cornwall and Devonshire it is known as a very old practice under the name of denshiring, supposed to have been introduced through the intercourse of Italians with our southern coasts.

Practice in Northamptonshire. - Mr. Baker's account is as follows:- "For this purpose the scouring of the ditches, any spare clay that remains after filling in drains, and any rough grass and soil obtained in trim- 
ming up hedge-rows, or levelling banks, are collected together. If there is not a sufficiency of weeds or other vegetable matter contained in the heap to burn the mass into the requisite red ash, a portion of refuse coal-dust or slag, as it is called, which may be obtained occasionally from the coal-merchants at the rate of about $5 s$. per ton, is used; as also the refuse bark from the tan-yards, which not only helps to consume the heap, but also affords, when burned, a fine alkali, which is very beneficial to the crops. This bark is frequently given away at the tan-yards to those who choose to fetch it. To burn a heap, a small fire of wood and coal is first lighted, which is covered over with a layer of clay, over which a few shovels-full of refuse bark or coal dust are scattered; when the fire begins to burst through, more earth is laid on, and the same process repeated until the whole heap is made up. Considerable judgment is required on the part of the workman to burn a heap properly; few excel at it, and the art can only be acquired by practice and attention. As soon as the fire has attained a good heat, the heap requires raking down rather flat, to afford a larger hot surface for fresh earth to come on ; and, in windy weather, care must be taken to apply the fresh material on the contrary side to that on which the wind lies, or one side will burn out before the fire touches the other. Mr. Collins, of Monk's Park, near Northampton, was, I believe, the first to introduce this practice, and he speaks most highly of the beneficial effect of burned clay to the land. $\mathrm{He}$ selected the worst and most neglected field upon his property to operate upon first. The soil was cold and stiff, and had the character of never having been free 
from weeds. His first step was to drain it thoroughly and deeply, and then apply a dressing of thirty or forty cubic yards of burned earth to the acre ; and he states that by the three first crops after the application, consisting of one of potatoes and two of wheat (happening in dear times), he realized the fee-simple value of the land; and he considers that the whole of his land ploughs one horse easier, now that it has all been dressed with ashes. Mr. Collins has made no calculation of the exact cost of obtaining a cubic yard of these ashes; but judging from the quantity of coal required for burning clay into ballast, or for roadmetal, I should consider that 3 cwt. of coal would be amply sufficient to burn a cubic yard of clay to a red ash, thus :-

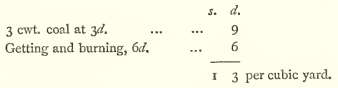

The principal secret in burning strong clay is tc throw it wet upon the burning clamp; the lumps then come out in a cracked state, and presently moulder down with the weather; if, on the contrary, it is laid on it in dry, hard lumps, it will inevitably burn into brick, and lie "knocking about" the land perhaps for two or three years before the frost will crumble it down. Common bricks are a proof of this; for if burned before being thoroughly dried, they will certainly turn out unsound and incapable of standing the weather.

Method in Ireland.-Like everything else, where there is a demand, the supply is encouraged, and throughout Ireland paring and burning is made a 
trade of, by persons who go about the country for the purpose, who earn what are considered by themselves and others good wages. The process is described in the Kilkenny Survey. When the ground is ploughed but once, and the rough sods are piled into large heaps, it is called "great baiting;" but when the land is cross-ploughed, and the turf shaken into small lots, it is termed "small baiting." In this manner if the fire be kept close and well covered, as in the making of charcoal, the soil is found to receive improvement rather than injury.

General Principles.-Paring and burning must not, however, be confounded with that of burning clay, for the former properly done, and burnt by a slow process of combustion, retains a large portion of its vegetative power, while the ashes of the humus have a beneficial fertilizing property, for these ashes attract with avidity moisture and ammonia from the atmosphere, while the surface is rendered more porus and friable.

Paring is done to the depth of one, two, and three inches, according to the nature of the soil. Upon a clay soil, the paring should seldom exceed an inch in depth. On peaty soils, or where it is rooty and fibrous, it should be done thicker, but where the soil is shallow it cannot be cut too thin, but it must be borne in mind that the object is to get at the root of the weeds, and a soft spongy surface must be pared thicker than one bare of grass. Although attended with the best results on stiff, tenacious, heavy land, sandy soils are often impaired by burning, and in the case of light, open, and friable soils it is generally unadvisable. In the Annals of Agriculture a course of experiments is alluded to, made upon a farm in the West Riding of 
Yorkshire, where the sward was burnt all over the surface in the state in which it was left when pared; when, without any further culture, or seed, a spontaneous plant of luxuriant grass sprung up, and afterwards continued permanent, upon black peat earth, which formerly produced nothing but heath and ling. Similar experiments have been since tried with equal success, by only adding the seeds of white clover, trefoil, rye-grass, nonsuch, or any of the other grasses commonly intended to produce pasture, and merely harrowing them in without any ploughing.

The indiscriminate paring and burning of sound land already clothed with good, sweet herbage, and which has been continuously enriched by the pasturage of sheep, has in some instances been found to be permanently injurious, and it is such examples as these which has caused the operation to be unfavourably spoken of very frequently, and the success of paring and burning must depend entirely upon the nature of the land. Wherever the soil is already light, burning makes it lighter, but on heavy land it is invariably found beneficial. As a precaution, however, before resorting to paring and burning, it would be best to observe what has been the results of the practice in that part of the country, and whether it be favourable to the future production of natural grasses. On old worn-out sainfoin, and foul couchy leys of every kind, it is found the most economical and thoroughly cleansing process which can be adopted.

Method of Paring.-The most usual method of performing the operation of paring is by means of a tool called a "paring-spade" or "denshare;" in Scotland a "flawter spade;" and most frequently 
a "breast-plough," from the old-fashioned method of using it, when pushed by the breast of the man who ploughs, though now it is usually pressed forward by a board, or pads of wool fixed by straps to the front of the thighs, the blade being almost 13 inches long, terminating in a broad angular point.

It is very hard labour, and requires a strong man to perform it, but a good hand, where the land is not too stiff, will pare an acre in four days. The sods, when turned over, should lie in the best position for exposure to sun and air. A broad axe, which goes under different provincial terms, as "paring mattock," "beating axe," "cobbing-hoe," and "kaib-batt," is used for cutting through any stems or other obstacles which offer resistance to the blade of the "breastplough."

When the sward is very tough, horses are employed (as in the fens of Cambridgeshire), attached to the "Dutch paring-plough." In some of the moss-lands of Lancashire they shoe the horses in pattens to prevent them from treading down the soft spongy land. In Berkshire they use a shim, the share being made to rise or sink at pleasure, which affords facility for regulating the depth of the paring. In other parts of the county, though not frequently used, they have a broad share, the framework of which rests upon a pair of wheels, drawn by four horses, which gets over a good deal of land. Implements have recently been made for this purpose of a somewhat different construction, and the operation may be performed by the common plough, to which a share, two feet in width, is attached, deprived of the mould-board. It is fixed by two standard irons to the beam of any plough, before the 
coulter. It will be found an useful contrivance for other purposes as well, and will often save much labour on light soils by cutting through bean, tare, pea, and other stubbles about two inches below the surface, and while not turning any furrow, yet leave the weeds and roots all cut through, which can be easily harrowed out, and raked into heaps, and then disposed of. The old-fashioned plan used to be to burn them, but better uses can be found for these by employing them for litter, at times, as explained elsewhere.

When the turf is dry enough to burn, it is gathered together in large heaps and fired. More or less fire is needed according to the readiness of the soil for burning, of which experienced hands can judge. The turf should be so placed as to keep the fire from escaping outwardly, and where it breaks through the heap, the openings should be stopped up with turf, and the whole covered with fine mould and ashes. When once thoroughly alight they will always burn well. This is the method generally practised in Kent. In the East Riding of Yorkshire, it is usual to pare the sods as thin as possible, and as soon as sufficiently dry for the purpose, they are collected partially in heaps, four or five yards distant from each other, forming them into a half cone. Fire is then applied to each, but is prevented from breaking out by smothering it up with the remainder of the sods. The best cultivators open out these heaps when half burned, and spread them over the land with a shovel. The outsides, which remain unburnt, are heaped up whilst sufficiently on fire to be consumed, and thus all is burnt equally. 
Paring and Burning Bogs in Ireland.-Paring and burning bogs in Ireland has been thus described by Curwen:- " Round a space from six to ten feet in diameter, a trench of a foot deep, and of the same width, is dug, the soil from which is laid on the adjoining surface of equal breadth. Beyond this another circle of sods is taken out, and laid to dry in the same manner; and thus the work proceeds, until the quantity dug, with that which is left undisturbed for a floor, is as much as can be properly burnt on the space in the centre. As soon as the sods are sufficiently dry, some are gathered together, the heap is set on fire, and additions are made of wet and dry sods from time to time, so as to keep a regular, moderate, and smothered fire; in proportion to the attention paid to which particulars, the husbandman is rewarded by the quantity of potatoes he will procure."

A common plan is to put the sods into heaps of the size of small hay-cocks, keeping them in such a form as to be sufficiently hollow inside as to allow of the fire burning, but the outsides flat, smooth, and even, to keep in the heat. Some skill is required in the management of this method, for if made too large the weight of the heap crushes them down, while if too small the fire bursts out, by which the operation is not so effectually performed, as the flame spends itself prematurely. In wet weather small heaps of four or five cart-loads have been found too small, and a plan is described in the General Report of Scotland where the tendency of large heaps to "cave" in is obviated by a simple apparatus consisting of a few small iron hoops, the halves of which are placed so close together in the shape of an arch or semi-circle, as to prevent 
the sods from falling through upon the fire, riveted to two iron rods which lie lengthwise upon the ground, which thus forms a light, portable furnace, as it were, four feet long. When the turf is laid upon this, an opening is left through the hoops, which increases the current of the air.

Those who have not given the subject of paring and burning any consideration will be enabled to gather from the foregoing the kind of soil most likely to be benefited by the operation. Of the three principal soils, calcareous, siliceous, and argillaceous, Mr. Boys, who tried a great number of experiments in Kent, says he has always found the last least, and the first most improved by burning; but he never knew a single instance of the burning of any part of the soil, without having the effect of increasing its fertility in a greater or less degree. Notwithstanding this favourable testimony, where soils are poor and shallow they have an unfavourable effect, and on down lands which at one time furnished tolerable sheep pasture these operations have been prejudicial, and the loss of the old turf has been sensibly missed in Wiltshire, Hampshire, and some parts of Norfolk. Mr. Vancouver says that in King's County and Queen's County, and other parts of Ireland, where paring and burning the thinly-stapled high lands has been unfortunately practised, extensive and naturally-fruitful tracts have been reduced to the lowest and most exhausted state of barrenness and poverty, which has resulted from an abuse of the practice.

On the other hand, great benefit is to be derived from paring and burning when applied to fen, bog, morass or moory lands, and wastes covered with old 
gorse. These can immediately be brought into a state of cultivation, and the old rank vegetable matter, which in its previous state only choked and impeded vegetation, becomes an effectual dressing and valuable fertilizer, the effects of which may be traced many years afterwards; and if these lands are effectually drained (for without drainage the labour will be thrown away) by a proper system of cultivation, fruitful fields will take the place of what was previously barren wastes. 
The Management of New Leys, or Grass Lands-Experiments described by Mr. George Sinclair - Autumnal Management-Appropriate Lands to remain in Grass-Removing Obstructions to the ScytheAnt-hills-Mole-hills.

THE MANAGEMENT OF NEW LEYS, OR GRASS LANDS.A great difference of opinion exists with respect to the best course of management of new leys ; some contending that they should be pastured with sheep; others by no means sheep, which are likely to pull up the young plants, but with cattle instead; others that it should be mown for hay; wbile there are some who are of opinion that they ought to be seeded. But difference of situation must be taken into account. The mowing of new leys is attended with advantage, for if it is done early, and frequently rolled, the grass acquires a close bottom, and this plan should be invariably followed in moist meadows, where the soil is likely to suffer from poaching, and nothing is more damaging than to allow new grass to run to seed.

On the other hand, in many situations feeding with sheep has obtained the preference for the first two or three years, and when autumnal sowing has been followed in strong soils, the roots will have obtained too firm a hold to be pulled out of the ground by sheep, of which there is sometimes a danger, and the land of course profits greatly from the dung of the animals, the dictum having been laid down that, the more land is sheep-fed, the more it will improve. 
The sweetness of the pastures on many sheepdowns is said to be due to the closeness of feeding of sheep; and where ray-grass and white, or Dutch clover, are intended to remain for some years, it has turned out profitable to feed them the first year with sheep, which causes the grasses to grow close and thicker, and render them more permanent.

Experiments etescribed by $M r$. George Sinclair.The following experiments made on different soils are stated by Sinclair :-

A large field of heavy clay in Buckinghamshire, which had been much exhausted by long continuance under the plough (which would seem to meet the exigences of the case of some of the clay-land farmers at the time these lines are being written), was well cleaned, worked into as fine a tilth as the unfavourable nature of the soil would permit, and manured with farm-yard dung and coal ashes. The seeds were sown in August, at the collective rate of about four bushels to the acre, in different proportions in the order in which they stand, the largest being first, viz.-

Meadow fox-tail,

Meadow fescue,

Meadow cat's-tail,

The vegetation succeeded as satisfactorily as the season of winter would permit, but a top dressing was given in the following spring, and a few more seeds were sown at the same time. The pasture soon became fit to receive dairy-stock, and proved so productive, that, after a four years' experience of its qualities, another field of a similar soil, in the same farm, was also laid down. 


\section{II.}

In the second instance, the field, although worked in the same manner as the former, had the addition to the seeds, of cock's foot and perennial rye-grass, which proved a great improvement, and the field was intended to be sown in spring. In consequence, however, of the difficulty of getting a flat tenacious clay into fine condition, the ground was not sown until the beginning of summer; but although the seeds vegetated freely, yet such a quantity of charlock came up at the same time, that the plants were in danger of being choked, and it became necessary to give so thorough a handweeding, that it cost $12 s$. per acre. The grasses, however, sprouted vigorously, and in the course of two seasons became equal to any old pasture on a similar soil.

\section{III.}

A ten-acre field of strong loam incumbent on clay, in a high and exposed situation in the county of Cumberland, got a fallow of ten furrows, and having been harrowed and picked till not a weed was to be seen, was sown in drills, with thirteen pecks per acre of the following seeds :-

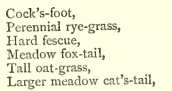

Crested dog's-tail, Sweet-scented vernal, Common meadow grass, White clover, Perennial red clover, Trefoil, and Broad clover.

The next year it carried upwards of forty wether sheep, with thirty-three lambs, and twenty yearling bullocks; thus keeping as much stock during the autumn as a common turnip crop, and making the sheep equally fat. 
IV.

A light gravelly soil, containing twenty-four acres, in Roxburghshire, was sown without a corn crop, on the I 3 th of April, I832, with $2 \frac{3}{4}$ bushels per acre of

Cock's-foot,

Meadow fox-tail,

Pacey's rye-grass,

Mixed fescu s,

Sweet-scented vernal,
Larger meadow cat's-tail, Common meadow grass, Broad-leaver bent, or fiorin, and White, peremial red, and yellow clover.

On the 28th of June, eight score of Leicester ewes, with their lambs, were put upon this pasture, and remained there until the 4th of August, when they were removed, but were replaced on the I $3^{\text {th }}$ by ten scores of ewes, without their lambs, which continued until the $4^{\text {th }}$ of October, at which period the account ends.

Mr. Sinclair's summary is, that with clean preparation and judicious manuring, any land may be brought in a couple of years into a state of permanent meadow or pasture, nearly approaching to that of an ancient date, by sowing the seeds of the appropriate grasses,

What these are may be seen from the lists I have given, in exact quantities ; that portion of the experiments quoted not being of any great value, as our knowledge has become more precise and definite, in this respect, since these experiments were made, which, however, are useful for the account of the numbers of stock placed upon the land. And although in amount of productiveness of crop, through a proper selection of grasses, as large an amount of herbage may be obtained from off these recently made pastures, the same quality of sward must not be expected, which is formed by the roots, and the mould made by the 
decomposition of the dead ones, which can only be produced during the course of several years.

Autumnal Management.-In the autumn, as the soil is moister, its being trampled upon by cattle and horses will be found very injurious, the land then being tender, and sensible to every impression. Every kind of stock, therefore, should be excluded throughout the following autumn and winter, for the small advantage gained from the feed obtained, will bear no propertion to the damage done to the land from putting stock upon it, which should therefore be carefully excluded. Manure is recommended to be put upon the land at this time; but if it has been properly laid down, it is not actually essential, though at all times it is beneficial; but should the soil be of a nature that may be considered unfavourable to grass, and when its success may be considered doubtful if manure be applied the first year, the best time for its application will be in August or September, when a moderate dressing will promote the growth of the herbage; or if mown, the best time to manure will be immediately after the hay is cleared off.

Appropriate Lands to remain in Grass.-In reference to the difficulty often existing of proper discrimination as to what species of land is best fitted for grass, and what is not, Mr. Davis, in his Communications to the Board of Agriculture, points out that the best meadow land does not always make the best tillage land, nor does the best arable produce the best pasture, but frequently the reverse.

The lands which are most proper to remain in grass, and which, if in a state of aration, ought to be converted into grass, are the following, viz. :- 
1. Lands in the vicinity of large and populous towns, where manure is cheap and plentiful, and where the produce of grass land is always in demand, and consequently dear.

2. Lands lying in the valleys of mountainous countries, particularly calcareous soils, where old meadow land is scarce and valuable, and where the greater part of the arable land is of such a nature that it is almost impossible to convert it into good grass land.

3. Lands situate near rivers or brooks, which are capable of being improved by irrigation to a much greater value than can possibly be effected under any other mode of culture.

4. All cold stony grass lands, which if ploughed up would be inapplicable to the growth of turnips, and to the general purposes of modern husbandry, and which, under the best system of wheat husbandry, would not be so valuable as they now are in a state of grass. An exception, however, occurs with regard to land of this description; for where sea-sand (as is the case on the north-western coast of Cornwall) can be applied at an easy expense as a manure, such land may be more profitably employed in tillage.

5. Peaty soils are also best adapted for yielding grass; for though they may be most perfectly reclaimed from producing rank, aquatic plants by tillage, yet, being too tender and too moist to continue long in a state of aration, they should be converted to the state of permanent grass land as soon as that object is accomplished.

Land intended for grass ought to be of such a description as that in which it will spontaneously 
flourish and thrive. If there is too much moisture, the grasses will be injured in the winter by rain and frost, and will soon be superseded by rushes and various aquatic plants. On the other hand, if the land is too dry, they will be killed by the intense heat of summer, and be succeeded by mosses, fern, or heath.

No land will make a good meadow unless it be sufficiently deep to admit the roots of grasses to run down out of the reach of the summer heat (it should be observed here that this correctly applies to the roots of ordinary grasses, but there are some kinds better fitted than others to stand drought, as the white or Dutch clover, which has a principal root which it sends deeply down into the ground in search of nourishment, and is by this means better enabled to sustain drought than some other descriptions), and also sufficiently retentive to hold water long enough to produce fermentation, together with such an absorbent substratum as will drain it before putrefaction takes place; and if it be not so by nature, it must be rendered so by art. On the contrary, if land be too dry and friable, ploughing will only render it more so. Grass land of this description, therefore, ought never to be ploughed, unless it can be made retentive by the application of lime, clay, chalk, or other fossil manures that can be procured on or near the spot, especially marl. Where either of these can be obtained at a moderate expense, and where good crops of grain have not only been produced, but also a tendency is promoted in the land to run again to grass, land of this description, that can be so managed, should be ploughed up, and after being a few years in tillage, particular care being taken not 
to exhaust it by corn-crops, may again be laid down to grass in a much better state than it originally was.

Removing Obstructions to the Scythe.-All new land intended to be laid down in pasture requires to be properly levelled, so that no obstructions are likely to come in contact with the scythe in mowing.

Ant-hills.-The process of getting rid of ant-hills has been described in Marshall's Rural Economy of Norfolk, who refers to it as an excellent plan of obtaining manure, these when burnt forming a capital basis for manure heaps, \&c. :- "With a heart-shaped spade or shovel, the hills were cut up in irregular lumps from ten to fifteen inches in diameter, and from two to six inches thick. The grass sides of these are turned downward until the mould side is perfectly dry, when the former is exposed to the air, until the heaps are sufficiently dry to burn. A fire is then kindled by means of brushwood, and kept smouldering by gradually laying on the sods or lumps, as the fire breaks out, until ten, fifteen, or twenty loads of ashes are raised in one heap. This is a cheap way of raising manure, while at the same time it removes a nuisance; and no man, having such an opportunity in his power, ought to neglect at least the making of an experiment. Ashes are on some soils an excellent manure; and perhaps, generally, ashes thus raised would be found highly advantageous as a basis or bottoming for farm-yards and dunghills."

Mole-hills.-The common method of removing mole-hills and capturing the moles appears first to have been communicated to the public and made generally known by Dr. Darwin in his Phytologia, the Doctor himself being indebted to the experience of a 
very successful mole-catcher, who communicated his method of proceeding, which has been narrated as follows:- This man commenced his operations before sun-rising, when he carefully watched their situation; and frequently observing the motion of the earth above their walks, he struck a spade into the ground behind them, cut off their retreat, and then dug them up. As moles usually place their nests at a greater depth in the ground than their common habitations lie, and thus form an elevation, or mole-hill, the next step is to destroy these nests by the spade; after which the frequented paths are to be distinguished from the bye-roads, for the purpose of setting subterraneous traps. This object may be effected by marking every new mole-hill with a slight pressure of the foot, and observing the next day whether a mole has passed over it, and destroyed such mark; and this operation should be repeated two or three mornings successively, but without making the pressure so deep as to alarm the animal, and occasion another passage to be opened. Now the traps are to be set in the frequented paths, and should be made of a hollow wooden semi-cylinder, each end of which should be furnished with grooved rings, containing two nooses of horse-hair, that are loosely fastened to the centre by means of a peg, and are stretched above the surface of the ground by a bent stick, or strong hoop. As soon as the mole passes half way through one of these nooses, and removes the central peg in its course, the hoop, or bent stick, rises in consequence of its elasticity, and of course strangles the mole. The simplicity of this mode of destroying mole-hills and moles, recommends itself to general adoption, as 
those whose grounds are thus infested may easily extirpate them, or teach the art to their labourers.

It is almost unnecessary to remark that this method is generally adopted, as may be evidenced by the frequent sight of an unfortunate mole suspended from a stick above a mole-hill. 
I06

\section{CHAPTER VII.}

Mowing-Hay-making-The Middlesex Method of making Hay-Wet

Weather in Hay-making-Hay-making in Hot Weather-Relative Proportions of Grass and Hay-Stacking-To ascertain the Heat of a Stack of Hay - To ascertain the Quantity of Hay in a StackCutting the Stack and Trussing-Real Solid Food contained in Hay.

MOWING,-The proper season for cutting the grass is a very important consideration, so as to secure the largest amount of nutrient properties contained in it as well as the effects of the crop upon the land, which if left too long standing, so that the seeds begin to ripen, greatly exhausts it.

As different kinds of grasses flower at different seasons, the necessity of mowing when the greatest number of useful grasses are simultaneously in flower, will naturally suggest itself, and this in mixed pastures will generally be about the middle of June, according to the season, when meadow fox-tail, sheep's fescue, sweet-scented vernal grass, sweet-scented soft grass, soft brome grass, \&c. will be ripe, and hard and smooth fescues, smooth-stalked meadow grass, and crested dog's-tail will be in full blossom.

If cut too soon, it will be very detrimental to grass crops, because the sap has not become properly elaborated throughout the blade, and when made into hay it shrinks very much, and hence the crop becomes comparatively small in quantity. $\Lambda$ gain, if cut too early, the bottom will not have become so thick as it 
ought to be; and in properly grown meadows it is commonly remarked that one inch of the bottom is worth at least two of the top, a circumstance also which points out the necessity of close cutting. If the mowing is, however, too much protracted, the plants become withered at the bottom, and the roots are injured; and this being the case, the aftermath or "eddish," as it is frequently termed, is both reduced in quantity and quality, so that of the two evils, it is better to cut too early than too late. According to this view, many growers consider it the safest plan to mow when the earlier grasses are in flower.

An improvement in the ordinary method of mowing grass was pointed out many years in the Complete Grazier as follows :- "According to the present mode of mowing grass, the labourers trace two parallel lines with their feet, which they move forward alternately, after every stroke of the scythe: in lieu of this method it has been recommended by the late eminent agriculturist, Du Hamel, to trace the mower's path in a single line only; because he ought to advance with one foot before another in such a manner that the left foot, which is behind, should always forward the right foot. By adopting this practice, it is stated that the labour will be performed both with greater dispatch, and also with more ease to the labourer, who will thus be secured from those sudden and painful cramps in the left side, with which they are often attacked in the common mode of cutting grass."

So many excellent machines are now in use for hay-making, that manual labour is of much less importance than it used to be, and is no longer such an important factor in harvesting operations of any kind 
in the present day as formerly used to be the case. Nevertheless, there will always be small quantities of mowing to be done that must perforce be performed with the scythe.

It was usual to employ a large number of hands in "tedding" the hay, i.e. spreading it out so that it might obtain the influence of the sun and air in drying it, after being freshly cut ; but the hay-tedding machine drawn by one horse will now do the work of fifteen hands upon level ground, and more effectually than it could be done by hand, turning the grass of thirty acres in a day, spreading it lightly and equally over the ground, and dividing the swaths with great minuteness and rapidity. The machine consists of two cylindrical sets of rakes side by side, each being worked by cog-work from the wheel next it, so that in turning the outer wheel will always give motion to that next it, and means are supplied for reversing the direction of its revolution. When first driven across the swath, the cylindrical frames revolve in a contrary direction to the wheels, as the machine progresses, the grass being carried over and under the machine, being tossed the while high in the air. The motion is then reversed after the first tedding, and the grass is thrown from behind it with considerably less labour, but almost equal efficiency, so that, lying evenly, it now is turned and winnowed.

These and similar labour-saving contrivances have altogether altered the amount of labour that it was one time necessary to employ in hay-making, but there is yet the putting of the hay into cocks to be done, and there will always be a certain amount of hand labour needed in hay-making that cannot be dispensed with. 
Hay-making.-In the neighbourhood of London a great deal of hay is grown of first-rate quality, there being a large market ready at hand for its disposal at all times.

The Middlesex Method of making Hay.-In the Corrected Report of the Agriculture of Middlesex, written by Mr. Middleton, the four days' proceedings are chronicled that are followed in hay-making, the process having been brought to great perfection in this county, which is considered to excel any other in the kingdom; for although the course of general farming in it may not rank so very high, yet its proximity to an unbounded supply of manure yielded by the stables of the metropolis, and the large consumption of hay, and consequently the large growth that takes place to supply the demand, has given for a long course of years great opportunities of practice under the most favourable circumstances, which are thus described under the old-fashioned method.

\section{FIRST DAY'S OPERATIONS.}

All the grass mown before nine o'clock in the morning is "tedded" or spread, and great care taken to shake out of it every lump, and to strew it evenly over all the ground. Soon afterwards it is turned, with the same degree of care and attention; and if, from the number of hands, they are able to turn the whole again, they do so, or at least as much of it as they can, till twelve o'clock or one o'clock, at which time they dine. The first thing to be done after dinner is to rake it into what are called single wind-rows, that is, all the hands rake in such a manner as that each person makes a row, the 
rows being three or four feet apart, the last operation of the day being to put the whole up into cocks.

\section{SECOND DAY'S PROCEEDINGS.}

The business of the second day commences with "tedding" all the grass that was mown the first day after nine o'clock. Next, the grass cocks are to be well shaken out into "staddles"-or separate flats-of five or six yards in diameter. If the crop should be so thin and light as to leave the spaces between these staddles rather large, such spaces must be immediately raked clean, and the rakings mixed with the other hay, in order to ensure its all drying of an uniform colour. The next business is to turn the staddles, and after that to turn the grass that was tedded in the first part of the morning once or twice, in the manner described for the first day. This should all be done before twelve or one o'clock, so tha the whole may lie to dry while the work-people are at dinner. After dinner the first thing to be done is to rake the staddles in double wind-rows-in doing which every two persons rake the hay in opposite directions, or towards each other, and by that means form a row between them of double the size of the single wind-row. Each of these double wind-rows are about six or eight feet distant from each other. Next the grass is raked into single wind-rows, then the double wind-rows are put into bastard cocks, and lastly the single wind-rows are put into grass cocks. This completes the work of the second day.

THIRD DAY.

The grass mown and not spread on the second day, and also that mown in the early part of this day, 
is first to be "tedded" in the morning, and then the grass cocks are to be spread into "staddles" as before, and the bastard cocks into staddles of less extent. These lesser staddles, though last spread, are first turned, then those which were in grass cocks, and next the grass is turned once or twice before twelve or one o'clock, when the people go to dinner as usual. If the weather has proved sunny and fine, the hay which was last night in bastard cocks will this afternoon be in a proper state to be carried, it seldom happening in dry weather but that it may be carried on the third day; but if the weather should, on the contrary, have been cool and cloudy, no part of it probably will be fit to carry. In that case, the first thing to set about after dinner is to rake that which was in grass cocks last night into double wind-rows, then the grass which was this morning spread from the swaths into single wind-rows. After this, the hay which was last night in bastard cocks is made up into full-sized cocks, and care taken to rake the hay up clean, and also to put the rakings upon the top of each cock. Next the double wind-rows are put into bastard cocks, and the single wind-rows into grass cocks, as on the preceding days.

FOURTH DAY.

On this day the great cocks just mentioned are usually carried before dinner. The other operations of the day are such, and in the same order, as before described, and continued daily until the hay harvest is completed.

In the course of hay-making the grass should, as much as possible, be protected both day and night 
against rain and dew by cocking. Care should also be taken to proportion the number of hay-makers to that of the mowers, so that there may not be more grass in hand at any one time than can be managed according to the foregoing process. This proportion is about twenty hay-makers (of which number twelve may be women) to four mowers: the latter are sometimes taken half a day to assist the former. But in hot, windy, or very drying weather, a greater proportion of hay-makers will be required than when the weather is cloudy and cool.

It is particularly necessary to guard against spreading more hay than the number of hands can get into cock the same day, or before rain. In showery or uncertain weather the grass may sometimes be suffered to lie three, four, or even five days in swath. But before it has lain long enough for the underside of the swath to become yellow (which, if suffered to lie long, would be the case), particular care should be taken to turn the swaths with the heads of the rakes. In this state it will cure so much in about two days as only to require being tedded a few hours, when the weather is fine, previous to its being put together and carried. In this manner hay may be made and stacked at a small expense, and of a good colour, but the tops and bottoms of the grass are insufficiently separated by it.

There are no hay-stacks more neatly formed nor better secured than those of Middlesex. Át every vacant time, while the stack is carrying up, the men are employed in putting it with their hands into a proper shape; and about a week after it is finished, the whole roof is properly thatched, and then secured 
from receiving any damage from the wind by means of a straw rope extended along the eaves, up the ends, and near the ridge. The ends of the thatch are afterwards cut evenly below the eaves of the stack, just of sufficient length for the rain water to drip quite clear of the hay. When the stack happens to be placed in a situation which may be suspected of being too damp in the winter, a trench of about six or eight inches deep is dug round, and nearly close to it, which serves to convey all the water from the spot, and renders it perfectly dry and secure.

The Middlesex farmers are desirous of preserving the green colour of their hay as much as possible, though a lightish brown is of no dis-service to it. Hay of a deep brown colour, occasioned by its having heated too much in the stack, is said to weaken the horses that eat it, by promoting an excess of urine, and consequently it sells at a reduced price.

In order to make hay come out of the stack of a fine colour, and the beauty of the flowers to appear, the hay that has been shaken out of bastard cocks to prepare for casting, should be cocked in the heat, and remain till the next morning; then turn and open the cocks for the air to take away the damp that is collected, which otherwise would heat in the stack, and of course the beauty of the colour would be done away with.

In the making of hay some attention should be paid to the quality of the soil, and the kind of herbage growing on it. The hard, benty hay of a poor soil is in little or no danger of firing in the stack; and should, therefore, be put very early together, in order to promote a considerable perspiration, as the only 
means of imparting a flavour to such hay, which will make it agreeable to horses and lean cattle; it will be nearly unfit for every other sort of stock.

It is the succulent herbage of rich land, or land highly manured, that is more likely to generate heat sufficient to burst into flame, as it has sometimes done; of course the grass from such land must have more time allowed in making it into hay. This the Middlesex farmers are perfectly aware of ; and when the weather proves moderately drying they make most excellent hay. But when very hot or scorching, they, as well as most other farmers under similar circumstances, are sometimes mistaken. In such weather the grass becomes crisp, and handles like hay before the sap is sufficiently dissipated for it to be in a fit state to be put into large stacks. But if that be done where it is thus insufficiently made, it generally heats too much, and sometimes becomes mow-bumt, and in some cases, though very rarely, has taken fire.

A method has been recommended for making hay, which has been followed to a certain extent under exceptional circumstances, in Anderson's Essay on Agriculture, where instead of cutting the grass when the dew is on it-the course generally followed, it cutting so much easier-it is recommended not to cut the grass till it is perfectly dry, when the swaths having had the sun for a few hours are to be made with small cocks in a pointed shape, as narrow at the base as possible; to remain in that state during one or two weeks, according to the weather, and then to be put into larger or "tramp cocks," in which after remaining a few days the hay will be fit to stack. The benefits resulting from this practice are said to be 
a considerable reduction of labour, and that the hay continues nearly as green as when it was first cut, also containing its natural sap in the greatest perfection; whereas by tedding and managing it in the usual manner, its juices are exhaled, and it is more subject to become injured by rain. Experience has however shown that, although this method may be found to answer during fine weather, and the hay is perfectly dry when first put into cock, yet as both these conditions can seldom be obtained, the method cannot be relied upon as one that can invariably be followed.

Wet Weather in Hay-making.-Wet weather is very trying in hay-making, the chief point to be aimed at in making hay being to protect it from both dew and rain, for water washes away the soluble salts, and when in the stack will cause the hay to ferment, and then injure it by destroying some of its most valuable qualities. The object of making the hay into cocks at night during fine weather when no rain is expected, is to preserve it from the night dews, which are often very heavy in summer-time, and the cocks should not be opened in the morning till the dews have evaporated. If rain falls when the hay is cut and lying on the ground, the less it is disturbed the better, and the less likely to take injury.

Many in their anxiety to make their hay, turn it with the purpose of making it dry, and if repeatedly dried and wetted again, it will become almost worthless; and many good farmers prefer to stand the chance of its becoming a little tainted in the stack, than have it exhausted of all its nutritive qualities, and it is considered better not to touch the hay at all when lying in the swath and saturated with wet, and 
not turn it over. Hay when mown wet has been known to preserve its nutritive powers for weeks when lying untouched.

Hay-making in Hot Weather.-In hot weather, on the other hand, the mown hay should not be allowed to remain long under the scorching rays of the sun without being turned, so as to prevent its getting comparatively baked up, when the colour and fragrance of the grass will be a good deal injured; the aim of successful hay-making being to retain the soluble portions of the grass as much as possible, and those which are soluble in water are starch, gluten, and sugar principally, which are needed by the animals that consume the hay for the support of life.

Relative Proportions of Grass and Hay.-It is roughly assumed that four parts of green grass will make one of hay, but the exact quantities as given by Dr. Thompson in the various experiments made by him are $387 \frac{1}{2}$ parts (by weight) of grass make 100 when formed into hay. A very large proportion of the soluble matters are thus lost during the process of converting the grass into hay, by washing out its sugar or decomposing its other soluble constituents. "These facts," says Dr. Thompson, "enable us to explain the reason why cattle consume a larger amount of hay than is equivalent to the relative quantity of grass. Thus, animals which can subsist upon IOO lbs. of grass should be able to retain the same condition by the use of $25 \mathrm{lbs}$. of hay, if the latter suffered no deterioration in drying; but experiments have shown that a cow, for instance, thriving on 100 lbs. to I $20 \mathrm{lbs}$. of grass, requires $25 \mathrm{lbs}$. of hay, and 9 lbs. of barley or malt." (Some particular experiment 
was here being alluded to, as 9 lbs. of barley or malt is a very large quantity to give to a cow.) And it is pointed out that water, when existing in hay from either of these sources, will induce fermentation, a process by which one of the most important constituents of the grass, namely sugar, will be destroyed. The action necessary for the decomposition of the sugar is induced by the presence of the albuminous matter of the grass; and the result is, that the sugar is converted into alcohol and carbonic acid; and that alcohol is produced in a heated hay-stack, in many cases, may be detected by the similarity of the odour disengaged to that perceptible in a hrewery.

The dryness of hay must depend too upon its quality and nature; coarse hay should be allowed to heat more in the stack, and requires less making than fine hay. Clover should only just be long enough in the swath to be sufficiently dry at the top, when it should be carefully turned over before the leaf has had time to become dry, brown, and brittle, for if the latter is allowed to take place, a good portion of the crop must be inevitably lost in dust, and what will be left will consist principally of the dry hard stalks, so that soon after it has been turned, and before it is fully withered, the swaths should be put up into small cocks, and the rakes should be industriously plied to get the straggling parts together that are left about.

I may as well observe here, that immediately a meadow is cleared of its hay, it is good economy to turn a few store cattle into it, to eat up the stray tufts of herbage that will be found in the neighbourhood of hedges, and out-of-the-way corners that have escaped the scythe. This will then be in an edible condition, 
and will be so much extra feed found for the cattle, for if allowed to remain till the after-grass is ready to be pastured off, it would be left by the stock, who would prefer the young springing grass, but they should only be kept there long enough to eat up the pasture left, and then be driven out of the enclosure.

Stacking.-I well remember the first hay-making I experienced on my own account. Having a good deal of grass-land, I had of course calculated upon the hay-harvest to make me a good return towards my expenses and rent, and I was naturally anxious to see the hay "got" in good condition. When the day was fixed upon when we were to begin cutting, which was settled after much deliberation between myself and my working foreman, the weather being a little showery, and we having decided to cut, trusted to the chapter of accidents that it would hold up by the time we carried, and were about to stack it ; so I hurried back from town as soon as I could, to join in the operations. $I$ had said nothing of my intention, knowing that as every hand would be wanted, and everyone pressed into the service, our operations being conducted upon the old-fashioned manner, I should have to take a man away from the work to drive me from the station in my dog-cart, so I walked home from it-a distance of three and a half miles-and found, as I expected, the house entirely deserted, only one odd hand keeping his eye upon the front door in case anyone called, and all the back entrances being fastened up. Maidservants, children, nursery governess, all had been impressed in the service, as my wife told me she intended doing, entering heartily into the matter with 
nie, and there they all were in their sun-bonnets busily engaged in spreading out the hay.

When I strolled into the house, to rest for a few minutes, there was not an animate object in it that I could see, save a gilded Cupid that formed the pendulum of the drawing-room clock, that was swinging merrily to and fro as the clock registered the passing minutes, as I just popped my head into the dining-room and drawing-room respectively, which are on either side of our somewhat wide hall-every soul had gone out hay-making, and I very soon joined them, working hard with the rest to secure an abundant crop which we had got. I was most at home at stacking I found, when the time came round, and I undertook to see to the proper ventilation of the stack, according to the instructions that were given me by my working foreman on the matter, for I had then but few ideas of my own; and these instructions were to tread the hay well down round a sack that was stuffed full of hay, and pull it up from time to time, keeping pace with the progress of the stack, so as to form a kind of chimney and ensure ventilation, and prevent the hay from heating. This is a very good method, no doubt, and it is one that may easily be resorted to, the objection to it being that, the hay around the chimney so formed is apt to become mouldy, but this may be prevented by covering up the chimney, or funnel, before the heat has all passed off. When the hay is well made there is not much risk of firing, but in wet weather there is often danger, and this may be averted by putting a few layers of straw in the stack at certain intervals, when the straw will be found to absorb the moisture from the heating hay, and so prevent its firing. 
This is a most useful precaution to take when making stacks of either sainfoin or clover. Sainfoin requires to be made as green as possible consistent with safety, while there is a large amount of succulence in clover, and by mixing layers of straw with them it absorbs their moisture to so great an extent, that when it comes to be cut up into fodder the straw will be found to have become almost as good as the rest.

No one who makes hay should be without a rickcloth. If not a complete apparatus, which is supported by poles and ropes over the stack while it is being built up, there should at all events be a cloth provided, sufficiently large to throw over the stack and protect it from the rain during the night, or even in the course of the day, while the stack is being built.

Not a moment should be lost when the hay is sufficiently made in getting it up to the stack, everything depending upon its being speedily secured in proper condition. Large ricks are better than small ones; if the hay has been properly made, the smaller the amount of surface that is presented to the atmosphere the better, but if the hay has not been secured in a satisfactory condition, then small stacks will be more advisable than large ones, and run less chance of heating.

The shape of the stack is not considered of much consequence, especially when the hay will be consumed on the farm, but circular stacks are deemed preferable when straw is scarce; but the square or oblong forms are much more convenient in cutting out the hay to form trusses for market, and they admit the air better to the stack. 
To asccrtain the Heat of a Stack of Hay.-It is often desirable to know the heat of a stack of hay so that risk of firing may be guarded against, and this may be discovered by thrusting in a sharp-pointed slender pole or iron rod, so as to give easy admission to a ram-rod or other contrivance, at the end of which is attached a strong worm. By turning this round, a tuft of hay may be screwed out at any portion of the stack, and the colour of the hay seen, or its heat ascertained. If the stack should be thought to require air, if it be perforated in several places with the sharppointed slender pole before mentioned, or iron rod, the risk of its heating will be avoided.

Should it unfortunately happen that a stack is evidently so hot as to be in immediate danger of taking fire, it should not be thrown down suddenly, which has been frequently done, for this from the sudden access of air will make it burst out into a flame; but the stack should be taken down carefully piecemeal, the exterior layers being cautiously removed, by which any sudden accession of air likely to fan it into a blaze will be prevented, for at times whole stacks of hay have been destroyed through being put up in improper condition.

To ascertain the quantity of Hay in a Stack.-As rough guesses are often a good deal out as to the probable amount of hay contained in a stack, which it is sometimes desirable to know, the measurement of a hay-stack with the object of ascertaining its weight can be easily managed after a definite method, if sufficient account is taken of the varying circumstances which may have influenced the composition, or building of the stack, the number of yards in a ton of hay depending 
upon the old or young condition of the grass at the time it was cut, and partly upon the dry or moist condition in which it was stacked, the general computation being, after a stack has been allowed to settle and has passed through the winter, that ten yards of solid hay in good condition will weigh about a ton. If it is a very large stack, and more than a year old, nine, and in some cases only eight, yards will make a ton.

Clover will generally take eleven or twelve yards to make a ton as it lies lighter in the stack; when put up in a very dry condition, as many as thirteen yards being required to make a ton, but the general average will be about twelve. The mode of calculation as given by Bayldon is as follows :- "Supposing the stack to be ten yards long at the bottom, and eleven at the eaves; four and a-half wide at the bottom, and five and ahalf at the eaves; and presuming it to be four yards in height to the eaves, and to rise three yards to point of the roof; in order to find the contents, the dimensions are summed up thus :-

$\begin{array}{cccc}\begin{array}{c}\text { Medium Length } \\ \text { Do Breadth } \times\end{array} & \cdots & \cdots & \frac{10 \frac{1}{2} \text { yards. }}{5} \\ \text { Do Height } \times & \cdots & \cdots & \frac{52 \frac{1}{2}}{5 \text { including one-third of the }} \text { rise of the roof. }\end{array}$

10) $262 \frac{1}{2}=261$ tons, or $29 \frac{1}{2}$ loads.

"If the stack swells out considerably towards the eaves, the height if taken against the sides will appear to be greater than it is in reality; it should therefore be measured by a pole set up perpendicularly to the eaves. When it is required to measure an irregularlyformed stack, the contents may be found by giving 
and taking proportionate quantities of the separate parts, or by measuring, or computing it in different divisions. If round, a more complete calculation is necessary, and can hardly be ascertained with accuracy without having recourse to geometry. A simple method, however, consists in measuring the circumference at the bottom, and at regular distances up to the eaves, which must be added together and divided by their joint number for a mean circumference; the square must then be multiplied by the decimal 07958 , and this product by the height up to the eaves, and one-third of the rise of the roof added together, and this divided by 27 (the calculation being made in feet) will give the product in decimal yards."

Cutting the Stack and Trussing.-When the time comes round for the stack to be cut, it should be begun at that end which is least exposed to the weather, and commenced at the left-hand corner. The binder begins his operations by forming "thumb bands" of the inferior hay for tying up his trusses, having a boy to help him, who holds both ends of a wisp of damped hay between his hands. The wisp is then caught with the crook of an implement, locally called a "windle," "twiner," or "throw-cock," which consists of a circular piece of iron, about a foot and a half long, enclosed in a hollow tube of wood. This is grasped in one hand, and the handle of the implement turned with the other, which causes the crook to revolve in the tube, and the hay-band is twisted in a minute. The bands being all ready, the stack is measured for the size of the cut, which is made of the size of a truss of hay, being as nearly as possible three feet long, and two and a half feet wide, its thickness 
being regulated by the coarseness, or fineness of the hay; the finest hay of course making the thinnest trusses. The trusser then mounts the ladder, and cuts perpendicularly through the thatch into the stack sufficiently deep to enable him to get out the required number of trusses, using a hay-knife with a broad and sharp blade, specially made for the purpose, which measures about thirty inches long, and six broad, with a handle made short and straight from the blade in an opposite direction from it, so that it can be leant upon in thrusting the knife into the stack, which demands the exercise of no little amount of strength. The hay being cut in the proper directions to form the proper shape of the trusses, a long iron spike, about three feet long, with a handle, is then thrust into the cut portion, which long experience enables the operator to judge pretty correctly of the quantity required to form a truss, which is laid upon two bands stretched out upon a weighing-machine, furnished with a $561 \mathrm{~b}$. weight, when a little hay is added or taken away from each truss as may be required: (steel-yards are sometimes used for the purpose). The bands are then fastened round the truss at the distance of about ten inches from each end, and are afterwards turned under in a neat manner, and the truss is then complete. A good haybinder will truss two loads in the course of a day.

Real Solid Food contained in Hay.-Hay ranks very high in the amount of solid food it contains, as may be seen from the annexed table of analysis prepared by Dr. Lyon Playfair:- 


\begin{tabular}{|c|c|c|c|c|c|c|}
\hline & \multirow{2}{*}{\multicolumn{3}{|c|}{. }} & \multirow{2}{*}{$\begin{array}{c}\text { Dry Organic } \\
\text { Matter, or } \\
\text { Real Food. } \\
\end{array}$} & \multicolumn{2}{|c|}{$\begin{array}{c}\text { The portions extracted } \\
\text { as useless are }\end{array}$} \\
\hline & & & & & Water. & Ashes. \\
\hline \multicolumn{4}{|c|}{ roo lb. of Ordinary Hay contain } & $\begin{array}{l}l o s . \\
76 \frac{1}{2}\end{array}$ & $\begin{array}{l}\text { lbs. } \\
16\end{array}$ & $\begin{array}{l}l b s \\
7 \frac{1}{3}\end{array}$ \\
\hline " & Linseed C & ake & " & $75 \frac{1}{2}$ & 17 & $7 \frac{1}{3}$ \\
\hline " & Peas & $\cdots$ & $"$ & 801 & 16 & $3 \frac{1}{2}$ \\
\hline ", & Beans & $\ldots$ & " & $82 \frac{\pi}{2}$ & 14 & $3 \frac{1}{2}$ \\
\hline$"$ & Wheat Str & raw & $"$ & 79 & IS & 3 \\
\hline$"$ & Barley-me & & ", & $82 \frac{1}{2}$ & $15 \frac{1}{2}$ & 2 \\
\hline ", & Oat-meal & $\cdots$ & $"$ & 89 & 9 & 2 \\
\hline$"$ & Bran & $\ldots$ & $"$ & 81 & 14 & 5 \\
\hline ", & Oats & $\cdots$ & " & 79 & I8 & 3 \\
\hline ", & Lentils & $\cdots$ & $"$ & $8 I$ & 16 & 3 \\
\hline ", & Potatoes & $\cdots$ & $"$ & 27 & 72 & I \\
\hline$"$ & Red Beet & $\ldots$ & $"$ & I0 & 89 & I \\
\hline$"$ & Turnips & $\cdots$ & " & IO & 89 & $\mathbf{I}$ \\
\hline$"$ & Swedes & $\ldots$ & " & 14 & 85 & I \\
\hline$"$ & White Car & rrot & " & 12 & 87 & I \\
\hline$"$ & Mangold V & Wurzel & $"$ & Io & 89 & I \\
\hline
\end{tabular}




\section{CHAPTER VIII.}

Rowan, or Aftermath-Fog, or Fogging-The Gibbs Process of Saving Hay-Stock on Pastures.

ROWAN OR AFTERMATH. - Rowan hay, as it is termed, or the second cutting of grass, is so extremely light that the scythe is sometimes apt to pass over the grass without cutting it, so that it always needs to be cut very early in the morning when the dew is on the ground. Consisting for the most part of leaves without stems, or stalks, it requires a long time to dry properly, and often has to lay a long while upon the ground at a season of the year when the dews are very heavy. There is consequently a good deal of risk in making it, and in consequence of its unsubstantial nature it loses very much in bulk, and takes a comparatively large quantity of grass to make a small stack of hay.

It is therefore considered the best plan to eat up the aftermath with cattle, a good deal being cut and carried from water-meadows for the use of cows, which eat it readily enough, but fattening stock do not thrive upon it.

Fog and Fogging:-In some parts of the north the second crop is called "fog," but this is not properly so understood, the term "fogging" being derived from a common practice in some of the Welsh counties of keeping the land without any stock upon it from 
May or June until December, and in some instances as late as March, by which the crop of hay is entirely sacrificed, though of course much later feed is obtained. In the Cardiganshire and Pembrokeshire Reports the method is described as follows:- "As early in May as we can, the fields are shut up for the summer season, and continue in that state until November or December, when all the stock is turned in, and every animal is in excellent condition without the aid of straw, hay, or oats, and the butter is as good as in any part of the year. The frost sweetens the grass, and snow does not injure it; but while it is buried, dry food must be resorted to. In the spring of the year, young shoots of grass are very forward, under the shelter of the old, and both are eaten together with great avidity. It has been thought, indeed, that the best acre of hay will not keep more stock, or in such good condition, as an acre of fog, with the additional advantage of avoiding the risk, and saving the expense of hay-making and manure.

"The stock, however, is not generally turned upon the land until February or March. By this practice the farmer provides a good stock of keep for that season of the year when he stands most in need of it-puts his cows into good plight for calving-saves a great deal of hay, and improves his grass lands by the quantity of seeds shed upon the surface by the fogged grass: his stock being out by day upon the fog, and in his straw-yard by night, augments his dung, which is the mainspring of his tillage management, and he gains in a great measure the advantages of a green winter crop."

The practice has been condemned, as a rule, by 
most good farmers, for it has been observed that where green grass has been left in autumn, the herbage of the next year is the coarsest and worst. Still, under certain conditions, it may often be worth a trial, for although not likely to be so useful upon farms which produce abundant root-crops, to those who run short of winter feed and have a good number of dairy cows to support, it might sometimes turn out advantageous, and prove a resource against scarcity of spring food. Where the plan is followed, however, it is necessary that the land should be naturally dry and sound, for if of a wet nature, the fog rots, and if too light, the crop dries up and withers before the season arrives when it is wanted to be used. Sinclair, $O_{n}$ Winter Pasturage, estimates the amount of waste by taking the quantity of reserved winter pasturage at one-half the produce of the herbage, and the deterioration in quality from age, as well as by the feet and droppings of the stock, at fully a-third, so that if to this be added the less advantageous effect upon the stock consuming it in the fields, instead of under cover or in the fold-yard, considers the loss incurred to be equal to one-half, and that the most profitable mode of consuming the produce as herbage of grass land or of a pasture, or rather that mode which will ensure the least possible waste of the food, is to consume it as it reaches within bite of the stock; and, consequently, the farther it is permitted to advance in growth beyond this depth or age, so much more or less waste and loss are suffered.

A great deal of hay is lost every year, or if not entirely lost, half spoiled by wet, much of which might be saved through means of the Gibbs process of saving 
hay, which up to the present has not been much resorted to.

The Gibbs Process of Saving Hay.-An apparatus has been invented for saving hay that has become damaged by wet, by Mr. W. A. Gibbs, of Gillwell Park, Chingford, Essex, and manufactured by the Bristol Wagon Works Company, which consists of two parts-a frame upon wheels, supporting a sheetiron reciprocating trough, along which the hay is slowly passed, subjected to a powerful current of heated air, and tightened up by rows of revolving forks or pickers; and another piece of apparatus on wheels, consisting of a combined furnace and fan supplying the hot air. The fan is driven by a portable steam-engine belonging to the farm. The first machine, about 30 feet in length, is not much unlike an elevator in appearance, but being in places about 12 feet in total breadth, it requires that some portions of its mechanism be removed when intended to be taken through farm gateways, and it is by the avoidance of such removal and replacement of parts, that time may be saved in changing from one scene of operations to another. Probably also, the heat of the double furnace of spacious coke fires might be utilised for making the steam necessary to drive the fans, and so dispense with the separate engine, from which only about fourhorse power seems to be really requisite.

According to the accounts that have been published relative to the practical working of the method, it would seem that it thoroughly dries into hay grass that has lain in the field, and does this as fast as two men pitching can send the carts, which is at the rate of four one-horse cart-loads per hour; and the extra 
labour required is that of two men, the force for carting and stacking remaining the same as without the machine.

From an account that has been given by Mr. G. P. Fuller of Neston Park, near Corsham, Wiltshire, it appears that this gentleman had mown II7 acres, and, the crop being light, by means of the Gibbs hay-drier that area of land was cleared in three weeks, notwithstanding the continuance of wet weather during a fortnight of the time, at a period when many hay farmers were mourning over their injured hay crops, Mr. Fuller testifying that the machine does what is required of it, namely, make hay, and it accomplishes the process well. So far as he can estimate, the expense of making hay by the artificial process is less than that in the ordinary way by weather drying. To save hay in that neighbourhood, by hire or contract, costs from 20s. to 25s. per acre. The cost to Mr. Fuller by the artificial drying, including mowing, making, carting, and stacking, but exclusive of thatching the ricks, is as follows, upon 43 acres cut and cleared in one week:-Mowing 43 acres, at 4 s., $£ 8$ I 2s.; eight men 35 hours, at $3 \frac{1}{2} d$., $£ 4$ Is. $8 d$.; three boys 35 hours, at $1 \frac{1}{2} d$., I3s. $1 \frac{1}{2} d$.; four horses 35 hours, at $4 d$. per hour per horse, $£ 26 s$. $8 d$. ; engine-driver 42 hours, at $4 \frac{1}{2} d$., I $5 s .9 d$.; coal for engine and coke for furnace, including haulage, $£_{3}$ I $6 s$. 8d.-total, $£_{20} 5 s$. ${ }_{10} \frac{1}{2} d$. This amounts to only $9 s$. $6 d$. per acre; but this crop was so light that only 30 tons of dried hay were made off the 40 acres, bringing the working expenses to $13 s$. $6 d$. per ton. The machine was at work only 23 hours, so that the rate of performance was about $I_{\frac{1}{3}}$ tons per hour. The wages are calculated 
at harvest price, including expense of beer, and ten hours to the day. It is assumed that if the interest, repairs, and depreciation on the prime cost of the machine were put at i 5 per cent., upon $£ 300$, charged upon only 30 days' work in a year,- - and it would be probably much more in the hands of a contractor drying for many farmers, $-30 s$. per day must be added, or about $£_{3}$ Ios. to the above amount, making the outside cost $£ 23$ 15s., or less than I6s. per ton. Mr. Fuller considers that if the machine could be produced in a cheaper form, it would be of very great advantage, and he adds that farmers ought to have learnt from the last season the difference of value between good and bad hay, but they have yet to find out the advantage of cutting grass early.

On the Duke of Manchester's Park Farm, at Kimbolton Castle, Huntingdonshire, hay has been saved in good condition as to nose and colour, after lying for a time cut, so as to wither the grass, and then passed once through the hay-drying apparatus; and the hay safe and good in one rick represented acres which otherwise would not have been got at all, until the drenching rains had washed all the goodness out of it. Some clover hay which had been treated by the machine in too hurried a manner showed signs of turning damp and mouldy; but the meadow hay remains as it was stacked, dry and sweet, without any indication of over-heating or sweating.

The writer in the Times who gives an account of these trials states that $\mathrm{Mr}$. Wallis, the farm manager on the Duke of Manchester's Park Farm, expresses himself most favourably with regard to the machine, while at the same time pointing out improvements 
which might be introduced in the arrangement and construction, to make the whole more easily portable, and more quickly removed and set ready for working in another place; and it may be the want of just the few alterations so presenting themselves in the working, which may have delayed the general adoption of the machine by landowners, large grass farmers, or machine-owners who steam-thresh or steam-plough for hire. The writer says, that these experiments prove that hay-drying by hot blast is not only feasible but successful on a practical business-like scale; and further, that it is economical in comparison with the cost of hay-making by the common, risky, and often ruinous open-air method. If this be indeed so, then we have in our hands the means of rendering the hayharvest a certainty. We can escape the miserable losses which occur every summer, attaining vast proportions in such seasons as have been experienced, and the grass upon hundreds of thousands of acres every year converted into hay defective in quality from weather deterioration, or inferior field management. We might always preserve with the nutritive properties, colour, flavour, and aroma of the higherclass meadow hay, worth, perhaps, pounds more per ton, and certainly several pounds more per acre. Have we not witnessed of late the wholesale destruction of good grass in the swath or nearly dried enough for carting and stacking changed in a few days into a sodden mass better suited for the dunghill? And not only does this stuff occupying the meadows in nearly every part of the country, in every condition of must and mouldiness, represent the waste of so much valuable winter provender for animals, but the quantity 
of bad hay recovered, is liable to lower the condition and imperil the health of precious live stock, for many a stock-breeder and many a dairy farmer has found to his cost the danger of feeding his cattle upon spoilt hay.

The writer further points out that in the use of the hay-drier the economy is not so much in the cheapness of the process-a single operation of carting the cut grass direct to the stack after a few days of exposure, without labour during that time-as in making what hay is saved absolutely secure against damage from weather, and this hay, worth, perhaps $\oint_{1}$ or $£ 2$ per ton more than if it had been left to the chances of the usual series of protracted operations in the field. It is represented that the adoption of such a machine is a question for large occupiers, and especially for landed proprietors. Three thousand landowners, with possessions ranging from 3000 to over a million acres each, and some 9000 more with upwards of 1000 acres each, have it in their power to promote an extensive introduction of hay-drying apparatus, particularly in connection with their home farms, where these noblemen and gentlemen, by saving their own and their tenants' hay crops, could prevent a loss in each case of $£ 200$ to $£ 2000$ in the first wet season. Is it too much to expect that the great proprietary class will come forward as pioneers in the application of such mechanical aids to agriculture as inventors have provided, but which are too costly to be purchased by individual occupiers of small or medium-sized farms ? Or must it be left for commercial companies to push through the kingdom a general employment of hay and corn-dryers and steam-ploughs ? 
Questions such as these are important, especially where there is a large amount of stock to feed, the probability being, as a rule, that more dairy stock will be kept than formerly, and this brings me to the amount of stock it is usual to put on pastures.

Stock on Pastures. - The quality of the grass upon different pasture-land varies extremely, and it is generally classed under the separate headings of bullock pastures and sheep pastures, and care needs to be taken to put the right kind of cattle upon it to suit the land, some of which is capable of fattening a beast of a hundred stones, while other land will only carry the smaller breeds of animals, as Scotch or Welsh. Those which will scarcely feed a seventy stone ox come under the head of second-class grazing land. Larger animals may, however, be placed upon the latter, if the natural feed is supplemented with a daily allowance of cake.

The pasture must be kept in that condition for the use of cattle known as a feeding state, when the grass is long enough to be gathered by the tongue of the ox, and therefore it is not considered advisable to place sheep upon them, which pick out the finer grasses and leave the coarser. Although milch cows require good succulent food, it is not considered good policy to place them upon the "bullock lands," as they are apt to make flesh rather than develop the secretion of milk. Young steers may be put upon the inferior pastures with sheep. After the fattened cattle have been disposed of, then both store cattle and store sheep should be put upon the pastures in good numbers so as to eat up the remains as quickly as possible, and allow them to be laid up again to make grass for 
a second stocking, by which means two sets of cattle may be fattened off in one summer.

Second-rate bullock lands are best devoted to sheep, the best of which are estimated to fatten from four to seven sheep per acre, according to their size, breed, and aptitude to fatten; heavy long-woolled sheep will need an acre for five, while half-bred Leicesters and Downs may be put on at thirteen to every two acres; Lincolns and Leicesters five to the acre.

Down, or hill pastures should be stocked with the leanest and most inferior animals of the flock, but not if they have been accustomed to a better, for no animal will thrive that has been taken from pasture of a certain quality to an inferior one. It is considered also the best practice to have a mixture of animals upon inferior grazing land, as one steer or heifer to five young sheep, and it should not be allowed to grow too fast so as to get ahead of the cropping powers of the stock upon it, for if so, it will get rough and unpalatable, and clumps of the coarser grasses will grow up and master the finer ones, and all ought to be eaten off clean before Michaelmas, so that no old grass is left for the winter.

Where sheep are kept, and mixed husbandry operations upon a large scale are carried on, the change is beneficial to breeding ewes, which, when their lambs are weaned, need a change of keeping to dry up their milk, and are put upon the stubbles. 


\section{CHAPTER IX.}

Artificial Grasses-Clovers-Varieties-Mixed Seed-Table of Proportionals of different Clovers in Crops-Unploughed Ground for Clover-Time of Sowing - Two Dangers - Manuring - Dr. Voelcker's Experiments-Experiments upon Light Soil-Advantage of using a Mixture of Superphosphate and Muriate of PotashMowing Clover-Harvesting-Analysis of the Ashes of Clover.

ARTIFICIAL GRASSES.-I now come to what are vulgarly, and perhaps improperly, called artificial grasses, as before stated, which are exceedingly valuable to the farmer, many of whom have no grass-land, or, at all events, a very small proportion, to their arable; and a good many cattle of one sort or another could be easily fed upon the soiling system where it is never attempted. Amongst the most important of the trifoliated plants is clover, which I shall speak of first.

Clovers.-Most of the clovers are indigenous to our climate, the white clover being mostly found in calcareous soils, where its seed is said to lie dormant for an immense length of time, and as described before is an excellent plant to use in laying down permanent pasture. The broad-leaved red clover is also a native species, though it is generally grown from imported seed, in the first place from Flanders, being called the "great clover," and its introduction has been looked upon as a very important step in the improvement of our tillage system. 
Varieties.-The variety of clover is very great, there being no less than one hundred and sixtysix species named in Don's descriptive list, but, as Professor Buckland pointed out, these varieties are mainly caused, in the approximating divisions, by the tendency of variation into which the different species are apt to diverge, and as many of them are insignificant in a farming point of view, the ten kinds which are named below are quite sufficient in number to which to direct the attention of the agriculturist. These are :-

\section{SECTION I.-FLOWERS ROSE-RED OR PURPLE.}

No. Botanical NAME.

I. Trifolium pratense

2. Trifolium pratense, var. perenne

3. Trifolium pratense, var, medium

4. Trifolium incarnatum
ENGLISH NAME.

Broad Clover

Perennial Cloyer or Cow- Perennial grass

Zig-zag Clover or Marlgrass

Carnation Clover
DURATION

Biennial

\section{Perennial}

Biennial or

Perennial

Annual

\section{SECTION II.-FLOWERS PINK,}

\section{Trifolium hybridum \\ 6. Trifolitum striatum \\ 7. Trifolium fragiferum}

Alsike Clover

Soft-knotted Trefoil

Strawberry-headed Trefoil
Biennial

Biennial

Perennial

\section{SECTION III,-FLOWERS WHITE.}

8. Trifolium repens

Dutch Clover

Perennial

\section{SECTION IV.-FLOWERS YELLOW.}
9. Trifolium filiforme
Io. Trifolium procumbens
Small-fiowered or Suck- ling Clover
Hop Trefoil
Annual
Annual

The Trifolium pratense, or broad-leaved red clover, which is commonly met with, was first derived from Flanders, which upon its first introduction was known as the "great clover," seems to flourish best in the 
drier pastures, and has become a general favourite; not only for its weighty produce, but for the great advantage derived by the land from its growth, which has been exhausted by a corn crop; but being a biennial plant it does not arrive at perfect maturity until the year after it is sown, and dying the next year it is generally broken up after the crops of that year have been removed, though it is not unfrequently allowed to stand the second year in pasture to afford rest to the ground.

Professor Buckman alludes to the Protean form of the plant as the farmer has to deal with it, some being more permanent than others; all more or less hardy; all more or less productive,-from the difficulty of procuring the seed of any particular type pure, though the value of the seed varies just in proportion as it is so, for, as he remarks, "if you have in a field three sorts of clover, one of which flowers a fortnight before the other, one of which has a tendency to vigorous growth while the other is stunted, the more prolific will take possession of the soil, and overpower its rivals; while it may incline to become an annual, and so, after a while, leave the ground to the dominion of weeds. clover.

There are, then, three desiderata with regard to

Ist. A good sort, or sorts.

2nd. Pure seed of the sort.

3rd. Seed from a known and suitable climate.

I. The sort of Clover. - If we go into any large clover field we shall find indications of the following forms :-

a. Trifolizm pratense (No. I), Common Red Clover 
Broad-leaved Clover.-Head of pink flower somewhat compact, leaves more or less broad. Plant smooth in proportion to its size (the small wild specimens being usually very hairy), stem purple.

b. Trifolizm pratense, var. pallidum, Pale-flowered Clover.-Head of very light pink flowers, large and full, nearly double the size of $a$, more or less hairy; stem green.

c. Trifolium pratense, var. album, White Clover.Flowers white, herbage a very light green; in other respects much the same as the last.

d. Trifolium pratense, var. perenne (No. 2), Perennial Red Clover.-Flowers less compact than the others, the whole plant having stems inclining to dark purple; leaves narrower, and always ovate.

e. Trifolium pratense, var. perenne, sub-var. pallidum, Pale Perennial Clover.-A larger plant than the parent form, due, like $b$, either to meadow or arable cultivation.

f. Trifolinm pratense, var. perenne, sub-var, album, White Perennial Clover.-Not common, but still, like $c$, an albino form, which is a prevalent variation in purple-coloured plants. It is, perhaps, more delicate in constitution than the others.

2. Mixed Seed.-Now all these forms of clover are usually much mixed, and unless the seed be very good, as regards purity of sorts (which must not be confounded with purity or cleanness of sample), they may be made out in any patch of clover. My own observations on six different fields, three of which professed to be seeded with broad-leaved clover, and three with perennial clover, are expressed in the following table :- 
TABLE OF PROPORTIONALS OF DIFFERENT CLOVERS IN CROPS, Proportionals of Varictics.

\begin{tabular}{l|c|r|r|r|r|r|r|r} 
& $a$ & $b$ & $c$ & $d$ & $e$ & $f$ & \\
I. & Broad-leaved Clover & 65 & 10 & 3 & 16 & 4 & 2 & 100 \\
2. & Ditto & 5 & 80 & 5 & 5 & 4 & $\mathbf{1}$ & 100 \\
3. & Ditto & 4 & 95 & $\mathbf{I}$ & $\frac{1}{64}$ & $\frac{6}{6}$ & - & 100 \\
4. & Perennial Clover & 20 & 10 & - & 64 & 100 \\
5. & Ditto & 16 & 4 & - & 75 & 3 & 2 & 100 \\
6. & Ditto & 5 & 10 & - & 24 & 60 & 1 & 100 \\
\hline
\end{tabular}

I. A very impure sample, nearly a fourth perennial.

2. Better, but far from good.

3. A fine field of Broad Clover.

4. More than a fourth Broad Clover.

5. Still impure.

6. Less like perenne than either; aspect almost that of Broad-leaved Clover.

I have spoken before of the desirability of having pure seeds, and the above affords a lively illustration of its necessity.

3. Trifolium pratense, var. perenne, Perennial Clover, or Cow-grass. - This is also a plant of luxuriant growth, though not equal to the former, its flowers being of bright purple, in larger heads than those of the common meadow clover, from which it is distinguished by a peculiar bend from each joint.

Sinclair says :- "When examining the rich grazing lands in Lincolnshire, I found this plant to be more prevalent than any other species of clover. In clayey districts, and in soils of a peaty nature, this species of clover was more conspicuous than in the alluvial soils. The natural appearance of this plant in these celebrated pastures is such as to recommend it strongly for cultivation. It being strictly perennial, and the rest only slightly creeping, it may be used for the alternate husbandry, for which the $T$. medium is inadmissible 
on account of its creeping roots, constituting what in arable land is termed twitch."

Continuing to quote Professor Buckman, who considers the three first forms to be mere varieties of the common Broad-leaved, or Red Clover, grown under different conditions, we pass on to-

4. Trifolium incarnatum, Carnation Clover, which is one now commonly cultivated. It is quick in growth, of a hardy constitution, and yields a large crop of herbage for sheep-feed in a most difficult part of the year, namely the end of April or the beginning of May. In its wild state it is a small and exceedingly hairy plant; by cultivation it becomes larger in all its parts, and highly succulent.

It is sown broad-cast on the corn stubbles, with only such slight preparation as scarifying, when it soon comes up, and after the young plants have escaped the rigours of winter, it begins to grow with such rapidity as to be ready for feed all of a sudden; this presents a difficulty, to remedy which the French profess to have a tardy variety (Trefle incarnet. tardif). "Having grown this," says Professor Buckman, "side by side with the ordinary market form, I decidedly conclude that if there be any difference it is not sufficient to be of practical importance. I prefer, therefore, to sow a limited portion of this trefoil for early feed, and to depend upon vetches for a succession.

"The best soil for this plant is sandy loam. On land of this kind I had a crop nearly a foot high and well covering the ground by the Ist May, and that in a comparatively backward season."

When first introduced, the crop used to be sown in ground which had been ploughed, when it was not 
found to succeed, and the feature used formerly to be noted as somewhat remarkable as thriving upon unploughed ground.

Unploughed Ground for Clover.-A writer in the British Farmers' Magazine, April I835, says:- "I have never known a single instance of failure when the seed was committed to an unploughed surface. In the beginning of 1833 , I sowed some upon a strong and rich soil upon a chalk bottom; the seedlings came up well, but in course of the winter all perished. In September Colonel Beach sowed a few acres in a field of a similar nature, and here again the crop was a failure. At a distance of 200 yards, upon soil precisely similar, and in the same season, a stiff unploughed wheat stubble produced as fine a crop as could have been desired; the farmer had previously pursued the same plan and has realized large produce."

5. Trifoliun hybridum, or Alsike Clover.-"This, too (continues Professor Buckman), is an exotic plant, but now too well known to need description. Well grown, it is a large and most useful plant, and has been recommended for soils reputed to be clover-sick, and I have occasionally met with good crcps when ordinary broad clover has failed, but have never observed it to possess that truly perennial character which some people claim for it. Our seed supply is mostly obtained from the continent, and it is very difficult to obtain it at all pure; one example I got, named 'pure Alsike Clover,' contained as many as 100,000 weed seeds in a pint, being quite enough to ensure a sufficient crop of weeds to smother the clover effectually, and this is doubtless a frequent source of failure in this crop." 
6. Trifolium striatum, Soft Knotted Trefoil, is a wild British plant which has been introduced to cultivation by Mr. Waldon. It is so small in its parts that the Professor does not recommend its cultivation.

7. Trifoliun fragiferum, Strawberry-headed Trefoil, is noted from the similarity of its herbage to that of White Dutch Clover. Its pink flowers and expanding head of calyces, which are red, and of the form of a strawberry, sufficiently distinguish the two, and this is of importance, since this species is indicative of cold clay land, while the $T$. repens delights in lighter soil.

8. Trifolium repens, White Dutch Clover, grown on light soils. This is sometimes called White Suckling Clover, a name probably due to the fact that ewes or early lambs do remarkably well upon it. If intended for hay it should always be mixed with the hop trefoil, Medicago lapulina, as it is otherwise apt to be short, and to root in the ground, a habit which enables it soon to recover the close biting by sheep: the more it is fed the more perennial is its habit.

9, 10. The Trifolium filiforme and Trifolium procumbens are two common forms of the smaller yellowflowered clovers. The first was formerly called suckling clover, and was recommended for cultivation for young calves, but the small quantity of herbage it yields is much against its use.

The Hop Clover, though it is the true hop clover of the botanist, is not the hop trefoil of the farmer, which belongs to the medics. It gets the name of hop clover from the peculiar aspect, like a bunch of hops, of the withered head of flowers which remains even until the seed is ripened. This plant was formerly cultivated, but its scanty and innutritious herbage soon 
brought it into disfavour, and caused it to be superseded by the Medicago lupulina, whose leaves are so much like those of the Trifolium procumbens as to have caused the transference of its name. There can be no doubt but that this medic is a most important addition to our list of plants of this family, for although it can be scarcely recommended for self use, yet in combination with red clover, or rye grass, or sainfoin, it is of great value. I this year made a crop of hay from a mixture of broad-leaved clover and medicago, which is calculated at about $2 \frac{1}{2}$ tons per acre, and had a patch in which it was mixed with sainfoin yielding as good a cut.

Clover is not at all particular as to soil. It will grow on the most sandy soils if sufficiently tenacious, or on the stiffest clay, but does best of all on marly land.

The white is best adapted to light calcareous land and to permanent pasture; when clover is sown upon light sandy soils, a rather exceptional treatment must be adopted, and the ground should be ploughed deep to secure the roots from the effects of frost.

Time of Sowing.-The operation of sowing, as to time, must depend very much upon the nature of the land, the kind of crop which it is to supplement, and the weather. When sown among oats in strong soils, it is usually sown in the month of March. Among barley, after turnips, some time during the course of April, or the beginning of May, is the usual time. Sometimes the sowing is delayed for a fortnight after the barley seed has been put in the ground when drilled, until the plants have taken root, after which the clover is sown, and bush-harrowed, and rolled, which both covers the clover-seed, and fixes the roots 
of the barley more firmly, which is highly advantageous in light soils. When the barley has been sown broadcast, the clover follows the last harrowing; when the land is afterwards rolled down and unnecessary trampling of the horses avoided.

When following wheat, it is lightly harrowed in before the young crop has got very far ahead; or if it be winter proud, it has been found to answer well to feed it down with sheep, and when the land has been harrowed, to sow the clover seed and afterwards roll it.

About Io to I 4 lbs. of clover-seed is usually sown per acre upon light soils, when sown with barley, but a larger quantity, varying according to circumstances (from I 2 to I8lbs.), with wheat or oats upon cold clay, poor soils necessitating the use of a larger quantity of seed than those of a richer quality. When the crop is intended to stand for a second year, it is considered expedient to sow about 4 lbs. of white clover with it in place of a similar quantity of red.

Two Dangers.-As different circumstances affect the time of sowing, and make a corresponding difference in the growth of the plant, the rule should be laid down of always sowing as early as possible. Clover is exposed to two principal dangers; frost sometimes injures the crop, or it is burnt up in seasons of drought for want of rain; in strong lands the roots strike downwards to a considerable depth, which protects them from the effects of frost which does not reach a long way into the earth; while the temperate coolness and moisture of a strong land guards against the effects of drought in a hot summer, at which time the clovers on shallow soils are frequently irretrievably injured. 
Manuring.-Dr. Augustus Voelcker says, "Where good farmyard manure can be obtained at a reasonable price, I have no hesitation in saying I believe it will be found the most efficacious and the most economical manure both for seeds and permanent pasture. Even at $\mathrm{I} 2 s$. $6 d$, or $\mathrm{I} 5 s$. per ton, I am inclined to think that first-rate dung will be found a cheaper manure than any mixture of artificials, however skilfully prepared it may be. But as in some places it is not possible to obtain a sufficient quantity of dung at any price, and as it may be wished to give the seeds a dressing, I would suggest for trial the following mixtures, the compounds of which may be purchased at an outlay of about $£ 2$ per acre :-

\section{"For Clover Seeds on Light Land-}

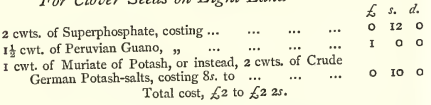

"For Seeds on Heavy Land, I would suggest a trial with2 cwts. of Nitrate of Soda, $\begin{array}{llllllll} & \ldots & \ldots & \ldots & \ldots & \ldots & 12 & 0 \\ & & \ldots & \ldots & 1 & 8 & 0\end{array}$

\section{Total cost, £2.}

For Permanent Pasture, I believe the following mixture will be found both efficacious and economical : \& s. $d$. $2 \mathrm{cwts}$. bone dust,

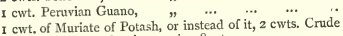

German Potash-salts, costing $8 s$. to $\ldots \quad \ldots \quad \ldots \quad$... to Total cost, $£^{2}$ Is. to $£^{2} 3^{s}$. 
"If the land is in a poor condition, one half more, or even double the quantity, of the preceding materials should be used; for on exhausted pastures it appears to be better to give at once a good dose of manure, whether natural or artificial, than to fritter away money in the purchase of small and inadequate supplies.

Before sowing, the artificial manuring mixtures should be diluted with as large a bulk of ashes as possible. With every bushel of the artificials at least three bushels of red ashes or burnt clay should be incorporated. If wood ashes can be obtained at a reasonable price, they will form an excellent addition to a clover manure. Coal ashes are but a poor substitute for wood ashes or burnt clay; however, in the absence of a better material, they may be used for diluting the artificials. The manures to be applied to the land not later than February."

In manuring clover lime should always be present in sufficient quantity. The scraping of roads, and road-side parings, hedge-refuse, \&c., will be found useful applications.

Dr. Voelcker's Experiments.-Dr.Augustus Voelcker relates in the "Journal" of the Royal Agricultural Society some very interesting field experiments which he caused to be made on clover seeds, with a view of obtaining a maximum produce at the least expense without injuring the land, and with this view he endeavoured to devise a manuring scheme which would recommend itself by simplicity, and include as far as possible conditions essential to success. After much deliberation he states he selected the following substances for field experiments :- 
I. Nitrate of soda.

2. Sulphate of ammonia.

3. Soluble phosphate, in the shape of dissolved bone-ash or mineral superphosphate.

4. Common salt (chloride of sodium).

5. Muriate of potash (chloride of potassium).

6. Sulphate of potash.

7. Sulphate of lime.

8. Mineral superphosphate and nitrate of soda mixed together in equal proportions.

9. Mineral superphosphate and muriate of potash mixed together in equal proportions.

Dr. Voelcker explains that in the first place he was anxious to ascertain what the effect of potash would be upon crops, which, like a clover crop, removed from the soil a large proportion of this important element of nutrition, but being made somewhat late in the season, the experiments were not so conclusive as he could wish, but the result does not warrant him to recommend the artificial supply of potash to the generality of soils, even when it is intended to grow plants which are known to require much potash for coming into perfection; but some of the trials were failures, those made both in I 862 and I 865 turning out so ; but he records a series of successful ones made by Mr. Jacob Wilson, of Woodhorn Manor, Morpeth.

"The field selected for the experiments was thoroughly drained four feet deep in the year I857, and otherwise in a good state of cultivation. It grew a heavy crop of wheat in 1863 , upon which mixed clover and rye-grass were sown by a broadcast drill, and horse-hoed in by Garrett's horse-hoe. The whole 
field was one of 20 acres, and had a gentle slope to the south-east. From a part where the plant was most regular, half an acre was measured out, and divided into ten equal plots of one-twentieth of an acre each.

"The ten plots were treated as follows, as regards manure, each plot being one-twentieth of an acre:

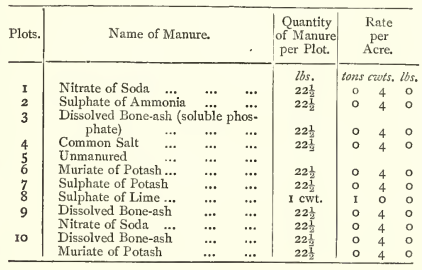

"The artificial manures were applied on the $23 \mathrm{rd}$ April, and the clover was cut on July 6 th, 1864 , and the produce from each crop carefully weighed, when the results contained in the subjoined table were obtained. 
TABLE SHOWING THE PRODUCE OF CLOVER SEEDS (MIXED CLOVER AND RYE-GRASS) IN LBS. ON EXPERIMENTAL PLOT OF AN ACRE EACH, MADE AT WOODHAM MANOR, MORPETH, IN I862, AND PRODUCE CALCULATED PER ACRE.

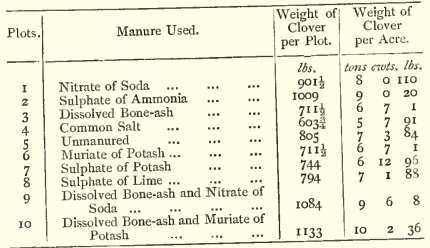

"The preceding figures, in the accuracy of which every confidence can be placed, are curious in many respects. They show, amongst other things :-

" I. That neither muriate nor sulphate of potash gave an increase; on the contrary, both forms in which potash was used appear to have diminished, to some extent, the produce.

" 2. That the unmanured plot (No. 5) gave about the same produce as that to which sulphate of lime was applied.

"3. That mineral superphosphate, or dissolved bone-ash, has had a less beneficial effect than sulphate of lime.

"4. That common salt diminished the produce to a considerable extent.

"5. That nitrate of soda alone, and still more sulphate of ammonia, produced a very considerable increase in the grass crop. 
" 6 . That the addition of soluble phosphate of lime (mineral superphosphate) to nitrate of soda had a very beneficial effect.

" 7 . That the highest produce was obtained on plot IO, on which mineral superphosphate and muriate of potash had been used. The produce of Io tons $2 \frac{1}{4}$ cwts. per acre is large. It is remarkable that whilst plot 3, manured with mineral superphosphate, and plot 6 , manured with muriate of potash, gave precisely the same produce, which was somewhat less than that on the unmanured part of the field, the mixture of both manures on plot ro gave the largest weight of mixed clover and grass per acre of any of the Io experimental plots.

"It must be confessed that some of the facts brought out in these experiments are opposed to what we know of the efficacy of fertilizers such as superphosphate and gypsum, and I do not believe for a moment that the latter is superior to the former as a manure for 'seeds.'

"It is well known that very soluble manures, such as muriate of potash or even common salt, occasionally have rather an injurious than beneficial effect on vegetation; but it is difficult to understand why two manures, which each separately gave no increase at all, but rather diminished the crop, should when mixed together produce such a beneficial result as in plot Io."

In the following year, Mr. Wilson undertook to carry on the clover experiments, and the same topdressings which were used in 1864 were applied again in I865 on May 8th to to plots of clover-seeds in precisely the same quantities as before.

In 1864 the crop was reaped on the 6th of July, 
when it did not appear to make any further progress; in 1865 it was left 12 days longer on the ground, as it was all the while in a growing condition. The results obtained are incorporated in the following table:-

"TABLE SHOWING THE MANURES EMPLOYED AND GREFN PRODUCE FROM THE IO PLOTS OF CLOVER-SEEDS, SECOND YEAR'S GROWTH, AT WOODHORN MANOR, MORPETH, AND PRODUCE CALCULATED PER ACRE.

\begin{tabular}{|c|c|c|c|c|c|c|}
\hline Plots. & Manures. & $\begin{array}{l}\text { Quantity } \\
\text { per } \frac{1}{\frac{1}{3}} \text { of } \\
\text { an acre. }\end{array}$ & $\begin{array}{l}\text { Produce } \\
\text { per } \frac{1}{2} \text { of } \\
\text { an acre. }\end{array}$ & \multicolumn{3}{|c|}{$\begin{array}{l}\text { Produce } \\
\text { per acre. }\end{array}$} \\
\hline & & lbs. & & tons & cuts. & $26 s$. \\
\hline I & Nitrate of Soda & $22 \frac{1}{2}$ & 8991 & 8 & 0 & 65 \\
\hline 2 & mmonia & $22 \frac{1}{2}$ & $1039 \frac{1}{2}$ & & 5 & 70 \\
\hline 3 & bate & & & & & \\
\hline & & $22 \frac{1}{3}$ & 924 & 8 & 5 & o \\
\hline 4 & Common salt & $22 \frac{1}{2}$ & 726 & 6 & 9 & $7^{2}$ \\
\hline 5 & amanured $\quad . .$. & & $635 \frac{1}{4}$ & 5 & 13 & 49 \\
\hline 6 & ate of Potash ... & $22 \frac{1}{2}$ & $767 \frac{1}{4}$ & 6 & 17 & I \\
\hline 7 & nate of Potash... & $22 \frac{1}{2}$ & $709 \frac{1}{2}$ & 6 & 6 & 78 \\
\hline 8 & Sulphate of Lime ... .... & I cwt. & $577 \frac{1}{2}$ & 5 & 3 & 14 \\
\hline 9 & $\begin{array}{l}\text { Mineral Superphosphate } \\
\text { and Nitrate of Soda }\end{array}$ & $\begin{array}{l}22 \frac{1}{2} \\
22 \frac{1}{3}\end{array}$ & 1056 & 9 & 8 & 64 \\
\hline Io & $\begin{array}{l}\text { Mineral Superphosphate } \\
\text { and Muriate of Potash }\end{array}$ & $\begin{array}{l}22 \frac{1}{4} \\
22 \frac{1}{2}\end{array}$ & 6681 & 5 & 19 & 37 \\
\hline
\end{tabular}

"On looking over the preceding results, the small produce on plot io must create considerable surprise. In the preceding year the harvest crop was reaped from this plot, and the result in 1865 is the more remarkable. Mineral superphosphate alone applied to plot 3 gave nearly 2 tons and 8 cwts. more per acre than the same quantity of superphosphate and muriate of potash added to it. There is, however, generally a good reason to be found for such striking anomalies as this.

"In the case before us the anomalous result obtained on plot Io is entirely attributed by Mr. Wilson to a bed of coltsfoot, which sprung up at one end of the 
plot. The effect of the top-dressing was very marked at the other end, where the crop to all appearance was very heavy. It is much to be regretted that the failure occurred just on plot IO, for there is strong presumptive evidence that muriate of potash is most usefully applied to clover in conjunction with superphosphate. Indeed the experience of the previous year seems to afford a substantial evidence for the correctness of this view.

"The effect produced by muriate of potash, it will be seen, was slightly better than that of sulphate of potash. In either case, however, the increase over the unmanured plot is not sufficiently great to repay for the outlay. It will, moreover, be seen that chloride of sodium (common salt) gave nearly as great an increase as muriate of potash, and slightly more clover than sulphate of potash.

"Nitrate of soda, and, in a higher degree, sulphate of ammonia, produced heavy crops, but of the mixed clover and rye-grass the latter predominated, and the grass was coarse, as it always is when nitrogenous manures are applied to it in considerable quantities.

"The most favourable result, it will be noticed, was obtained by the mixture of nitrate of soda and superphosphate on plot 9 .

"In comparing the weights of green clover-seeds in 1865 with those obtained in the preceding year, it appears that, excepting the anomalous result on plot 10, general experience gained in 1865 accords well with that of the preceding year. The comparison, however, brings out some differences, which appear to me to involve points of practical interest.

"In the first place, the unmanured plot 5, as might 
have been expected, produced a good deal less seeds in the second year than in the first year.

"In accordance with the experience of the preceding year, sulphate of lime (gypsum) had no beneficial effect, the actual weighings, indeed, showed a slight diminution in both years on the plots to which it was applied. It is possible that the employment of so large a dose of gypsum as I ton per acre may have had some share in depressing the produce; but more likely that the differences in the unmanured plots and plot 8 (gypsum) are not greater than those which would have been exhibited on two separate unmanured portions of the same field.

"At all events the experience with gypsum in both years proves that on the soil of the experimental field it had no beneficial effect. I mention this specially because gypsum is frequently recommended as a manure for clover, and because this is not a solitary instance in which I have failed to get the least indication of its favourable action on clover-seeds.

"In the next place I would direct attention to the much better effect which superphosphate produced in the second year than in the first. This I believe is attributable to the greater rainfall in 1865 , especially in the early part of summer.

"The greater rainfall in 1865 unquestionably explains likewise the differences in the effects produced by common salt and by muriate and sulphate of potash in 1864 and 1865 . In the former unusually dry year all three salts actually proved injurious to seeds, whilst in the latter they produced a marked increase, showing plainly the necessity for soluble saline matters becoming much diluted by the rainfall, and 
thoroughly diffused in the soil, before they can exert a beneficial influence on vegetation."

Experiments upon Light Soil.-Another series of experiments made upon light soil is thus recorded :-

"I have to record another series of experiments which were tried in 1864 at Barcott Lodge, by my friend, Mr. Robert Vallentine.

"The experimental field was rather light, and had not been in clover for many years-at least not for twelve or sixteen years. The crop (red-clover) was quite heavy and uniform throughout the field, and no difficulty was experienced in selecting for experiments a part evenly covered with clover. This part was divided in six equal plots of $\mathrm{I}-2 \mathrm{Oth}$ acre each, which received on the 27 th of April the top-dressings stated in the following table; the clover cut down in the middle of June, and made into hay. The produce from the several plots was ready to be stacked on the 20 th of June, and the weighings of the hay were made that evening, within the space of three hours.

"TABLE SHOWING THE WEIGHT OF CLOVER-HAY OF EACH EXPERTMENTAL PLOT OF $\frac{1}{10}$ OF AN ACRE, AND HAY CALCULATED PER ACRE, IN EXPERIMENTS MADE AT BURCOTT LODGE, LEIGHTONBUZZARD, IN 1864.

\begin{tabular}{|c|c|c|c|c|c|c|}
\hline Plots. & Top-dressings. & $\begin{array}{c}\text { Rule } \\
\text { per acre. }\end{array}$ & $\begin{array}{c}\text { Hay per plot of } \\
\frac{1}{10} \text { of an acre. }\end{array}$ & \multicolumn{3}{|c|}{$\begin{array}{l}\text { Clover hay } \\
\text { per acre. }\end{array}$} \\
\hline I & Nitrate of soda & \multirow{6}{*}{$\begin{array}{c}\text { cwuts. } \\
3 \\
1 \frac{1}{2} \\
4 \\
6 \\
3 \\
- \\
-\end{array}$} & $\begin{array}{r}\text { tbs } \\
304\end{array}$ & $\begin{array}{c}\text { tons } \\
2\end{array}$ & $\begin{array}{l}\text { cavts. } \\
14\end{array}$ & $\begin{array}{l}l b s . \\
32\end{array}$ \\
\hline 2 & $\left.\begin{array}{l}\text { Nitrate of soda } \\
\text { Superphosphate }\end{array}\right\}$ & & 306 & & 14 & 72 \\
\hline 3 & Common salt & & 270 & 2 & 8 & 24 \\
\hline $\begin{array}{l}3 \\
4\end{array}$ & Common salt & & 280 & 2 & 10 & 8 \\
\hline 5 & Unmanured & & 286 & 2 & II & \\
\hline 6 & Unmanured & & 284 & 2 & 10 & 80 \\
\hline
\end{tabular}


"It will be seen that the weights of clover-hay on the two plots left unmanured were almost exactly the same, and that the crop, considering the kind of land on which it was grown and the dry season, was very good indeed.

"It will also be noticed that the smaller dose of salt somewhat diminished the weight of clover-hay, and that the larger dose had a still more adverse effect. We may learn, if I am not mistaken, from the diminution of clover hay by salt, that it is not desirable ir average seasons to delay the application to the land of even very soluble saline matters until the end of April. Should the end of April or early part of May be wet, the dilute salt-solution distributed through a large mass of soil is likely to be beneficial, but otherwise it will do more harm than good to the crops to which it is applied. On the whole, therefore, my experience leads me to think it advisable to apply saline top-dressings earlier in the spring than they are generally made. Probably the beginning of March may be the best time in the majority of seasons.

"Neither nitrate of soda nor the mixture of nitrate of soda with superphosphate had any decided effect on the produce in clover-hay.

"The large crop on the unmanured plots, moreover, show plainly that the particular field on which the experiments were tried was in a high agricultural condition in which it did not require manure of any kind. It was, therefore, not well adapted for experimental purposes, at least in the season in which the experiments were tried. Ha 1 more rain fallen in the spring months of I 864 , it is quite possible that several of the top-dressings, more especially the mixture 
applied to plot 2, would have shown a much better result."

Advantage of using a mixture of Superphosphate and Muriate of Potas/l.-We select another example of the field experiments on clover seeds from the same paper to illustrate the fact pointed out by Dr. Voelcker that a mixture of superphosphate and muriate of potash often gives a large increase in grass-crops, whereas either manure applied alone has little effect, which is strikingly brought out in the experiments on permanent grasses.

"TABLE SHOWING MANURES USED, AND PRODUCE FROM PLOTS OF $\frac{1}{\sigma} \sigma$ OF AN ACRE EACH OF EXPERIMENTAL PASTURE, AND PRODUCE CALCULATED PER ACRE.

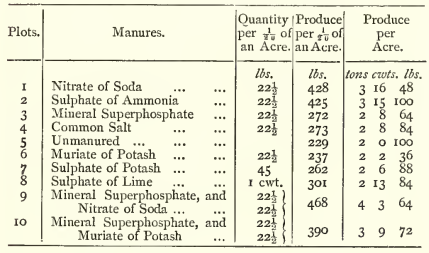

"The whole tenor of the preceding experiments tends to prove the impolicy of applying to cloverseeds exclusively phosphatic manures, or simple saline fertilizing agents, such as common salt, salts of potash, nitrate of soda, or sulphate of ammonia. The two last-mentioned salts, it is true, produce a large increase 
in weight, but in mixed 'seeds' this increase is realized at the expense of the clover-plant. On the other hand, the experiments teach us that mixed manures, containing phosphates and alkaline nitrates, or phosphates and salts of potash, promote the growth of clover-seeds on land not particularly well suited to them."

Mowing Clover.-The sooner clover is mowed the better, when a fair crop has got tolerably well matured, and the heads appear in full blossom. The error of cutting too early is always fully compensated by the increased growth of the second crop. When clover requires cutting, the lowest leaves at the bottom of the plant will begin to exhibit signs of decay. It should then be cut at once, for if the crop is allowed to stand on the ground any longer, it will lose more at the bottom than it will gain at the top. The time of mowing must depend, of course, very much upon the season, but it is generally ready about the first or second week in June, and if not cut down at once, it will be found a less profitable crop than it otherwise would have been.

Harvesting.-So as to retain the seed as much as possible contained within the flower, when the crop is preserved for seed, every precaution should be used to prevent the head from breaking off the dry and brittle stem, and it therefore is expedient to mow as early as possible in the morning, before the night-dew has exhaled. It should then be left in swaths, and not disturbed by the fork or rake till sufficiently ready to be put into small cocks, which should be gently turned over once or twice before carting home. The crop must be thoroughly dry before being carried, as the 
seeds will not part from the husks if they are at all moist.

We believe, however, it is more common to err in the opposite direction, especially with ordinary crops of clover, which are often dried up into the consistence of Bohea tea. A good deal of care and judgment should be practised in the management of clover, so as both to avoid the chance of heating, and yet to retain its due weight as much as possible.

On fair land, a crop of one and a half to two tons of clover-hay is got per acre the produce of the first cut, and about half that quantity perhaps at the second, according to the season.

The following is the analysis of the ashes of clover (Trifolium pratense) :-

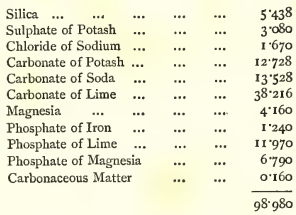




\section{LUCERNE.}

Preliminary Observations-Lucerne as an Article of Fodder-Growth of Lucerne on Thin Light Soils and Chalky Loams-Cleaning Lucerne with a Harrow-Lucerne in Wiltshire-Sowing - Hoeing-Harvesting-Mildew in Lucerne-Wide-standing Crops of LucerneLiability of Cattle to Swell from eating Lucerne-Lucerne eaten by Fly.

PRELIMINARY OBSERVATIONS. - La Lucerne is the famous herba medica of the ancients, which was so highly appreciated by them, and so much extolled; which after sowing was on no account to be touched with any iron instrument. At medica obruitur non aratra sed ligneis rastellis, and light wooden harrows were used by them for covering the seed. Lucerne is almost exclusively used cut green for feeding horses and cattle, and for summer feeding of cows it is said to be highly advantageous, improving the quality of the milk; much difference prevails as to the proper method of treating lucerne in its various stages of growth, but the best cultivators are unanimous upon the point that one of the first conditions of success is to keep the land clear of weeds, especially root-weeds and grass, by the use of the harrow, and also by handweeding; for if neglected the crop soon becomes unproductive. Although it will grow much longer, the crop is seldom allowed to stand more than eight years, as it generally becomes choked by that time in 
a greater or lesser degree. If the land is thoroughly well cleaned, the crops will improve every year.

It affords the most useful aid towards the maintenance of stock during very dry summers, and is ready for cutting sooner than any other of the grasses, in a favourable season being ready by the middle of April, at which period it will have attained the height of two feet.

It should always be cut before coming into blossom, when it will throw out fresh shoots, and will bear cutting three or four times more at equal periods up to the Ist November.

Lucerne thrives best on a loamy soil over chalk, or on soil mixed with particles of chalk; and is preeminently a lime plant. It is often sown with barley and oats, but as it requires a good deal of care and nursing at the first, and its growth may be very much impeded by being sown in conjunction with another crop, it is generally thought best to plant it alone, and under any circumstances the land should always be ploughed to its lowest possible depth, as the tap-root of lucerne strikes far down into the ground, and the under stratum is therefore of more importance than the upper, which may be modified by subsequent treatment which cannot be done with the lower, when once the crop is planted, and farmers have been disappointed at times in a crop of lucerne where their land, rich enough to grow good crops of corn and clover, yet lying upon a cold and impenetrable sub-soil, has been found unfitted for the growth of lucerne, and it has been found not to thrive upon clays, or upon ground too dry and parching.

Lucerne an useful Article of Foddcr.-Lucerne is 
such an useful item of fodder to grow, that no farmer should be without a piece, if his land is at all calculated for it, as it will be found invaluable for stock, as it is such a capital "cut and come again" article of provision. There is a well-authenticated account of eleven acres having supported twenty-three farm-horses in perfect condition, during twenty weeks, without any other food, as well as one horse being kept to constant road work, when soiled upon less than a rood of lucerne, from the 24th of May to the 2oth of November.

Although, as a rule, the land in Scotland is not very favourable to the growth of lucerne, in the Transactions of the Highland Society a case is recorded of a trial made with three cows fed alternately upon pasture and lucerne, with the following results:-

"After being kept upon lucerne for about ten days the milk of three cows was each measured by itself, and the produce in Scotch pints, was, on the 28 th of May, as under:-

No. I calved in Mareh and gave 13 pints.

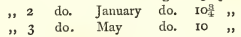

"They were then put alternately upon pasture and lucerne during the following periods, when the produce was found to be:-

\begin{tabular}{|c|c|c|c|}
\hline $\begin{array}{l}\text { PASTURE. } \\
\text { To Sth June. }\end{array}$ & $\begin{array}{l}\text { LUCRRNE. } \\
\text { To } \text { I }^{\text {th }} \text { June. }\end{array}$ & $\begin{array}{l}\text { PASTURE. } \\
\text { To } 13^{\text {th }} / \mathrm{Jul} y .\end{array}$ & $\begin{array}{l}\text { LUCERNE. } \\
\text { To I I th July. }\end{array}$ \\
\hline $\begin{array}{l}\text { No } 1.12 \frac{1}{3} \\
" \text { 2. } 9 \frac{1}{4} \\
" \text { 3. } 10 \frac{1}{2}\end{array}$ & $\begin{array}{l}129 \\
10 \\
10\end{array}$ & $\begin{array}{c}\text { Io } \\
91 \\
9\end{array}$ & $\begin{array}{l}\text { II } \\
\text { 10 } \\
89\end{array}$ \\
\hline
\end{tabular}

"The butter was of the finest quality."

Growth of Lucerne on Thin Light Soils and Chalky Loams.-The following letter was addressed to the 
Editor of the "Journal" of the Royal Agricultural Society, which is valuable as giving the account of one person's experience, though the recommendation of encouraging the growth of small weeds is quite against the generally received opinion on the subject:-

"MY DEAR SIR,

"As you were pleased with the crcps of lucerne which you saw growing on my thin chalky land, and ask for some account of their management, I have much pleasure in complying with your request.

My practice is to sow this crop after the land has been thoroughly well fallowed, highly manured, and sown with turnips, which are consumed on the land by sheep eating corn or cake; the land is then ploughed two or three times in the spring, thoroughly pulverised, and the growth of small weeds (if there are any) encouraged; the lucerne is then sown about the second week in May without any corn; $25 \mathrm{lbs}$. per acre will generally insure a good plant, which is very important ; $20 \mathrm{lbs}$. of this is drilled at about 7 inches apart, and the remainder, that which is emptied from the drill, is sown broadcast on the marks made by the drill coulters, before the land is harrowed; by this means the ground is well covered, and the small annual weeds are kept under by the crop. If the season is favourable, the field will give a nice cut for the scythe at the end of August or beginning of September, or else it may be fed with sheep or cattle; but it should not be depastured too closely. During the ensuing winter the lucerne should receive a good dressing of rich farm-yard manure, and in the spring some artificial manure would be very serviceable. In the second season a good fair 
produce may be expected, but the plant will not be in perfection till the following year. It requires a good dressing every year, and nothing pays better for it, as it will last six or eight years, and every year give three good cuttings. The first, even in our backward eastern climate, is ready for the scythe by the middle of May, and will yield 8 or ro tons of excellent green food, equivalent to 2 tons of hay. From its roots searching very deep for their sustenance, it is not so much affected by drought as the generality of plants, and shoots up almost immediately after the scythe, yielding in about eight or ten weeks another cutting of nearly two-thirds the weight of the first; and again, after a like interval of time, another cutting. This, of course, will not be so productive as either of the two former; but it may be confidently expected that the produce of the second and third cuttings will together equal the first crop. The crop is chiefly consumed by horses, the first cutting being much relished by them, and, with the exception of sainfoin, it is the most. hearty and nutritious green food that can be given. Horses are not so fond of the second or third cuttings as of the first, but still it is very valuable food, considering the difficulty of finding green food for stock in a dry season, and the certainty which a field of lucerne gives you of securing a good second and third cutting, however dry the season may be.

It is generally supposed that lucerne should be well hoed every year-a very expensive process,- - but if care be taken that the land is well prepared, and thus a full plant be got, and supplied every year with a good dressing of manure, hoeing may be dispensed with, and success ensured. After good crops have 
been cut consecutively for six or eight years, if the land be ploughed to a good depth, a skim coulter being used to bury the grass from the edge of the furrow, no fear of a good crop of oats need be entertained; in fact, after such a rest from corn as the land has had, two good crops may be taken in succession, should this be convenient for bringing the lucerne-land into the same course of cropping with the remainder of the field.

"I may sum up my letter by saying, that in my opinion no farmer should be without a plot of lucerne in due proportion to the size of his farm, and that I am sure no person who has ever laid down a picce properly will ever again be without it.

"I am, my dear Sir, yours very truly,

"Littlebury, June $\mathrm{Ig} / \mathrm{h}, \mathrm{1865."}$

"John Clayden."

In the above, there are several points recommended which are at variance with the experience of others. Hoeing and cleaning the land of weeds is generally considered the first prime necessity, and the principal thing that is needed in growing lucerne; being of even more importance than the application of manure.

Then again it is considered that farm-yard manure should not be used to lucerne, as it is likely to make the young plants tender, so as to injure their future growth, and also fill the land with weeds; and instances of this sort, where success is attained in growing crops by a method somewhat at variance with established ideas, very probably owes that success to general fitness of the soil, with good husbandry in other respects. 
Cleaning Luceme with the Harrow. - When the crop has got a firm hold of the soil, lucerne can be cleansed very well by the harrow. Some farmers would be afraid to do this, considering the harrow would tear up the plants, but these strike their roots so far downward by the second season, that no danger on this score is to be apprehended, and every succeeding year the scufflers and harrows should be set to work on broad-cast fields, to scarcify the land in every direction as deep as possible, for by this means apparently worn-out lucerne lands have-been brought into vigorous growth.

Lucerne in Wiltshire.-Tull relates an instance of some lucerne which had stood in Wiltshire for some years without attaining any substance of value, "though the land was whitish, and scarce any grass appeared amongst the lucerne, and therefore its poorness was thought to proceed from the soil being improper; but when it had been broke up, and sown several years with corn, and afterwards lain down with sainfoin, all the lucerne plants which remained (and there were many) grew large and strong, shooting up a yard in height soon after the sainfoin was cut; and if there had been a competent number of them undestroyed by the plough, they would have yielded crops of an extraordinary value, where before ploughing it grew but few inches above the ground.

"It seems that in this sort of land the earth grows stale ere the lucerne arrives at a tenth part of its stature. But this is most remarkable, that tillage transforms those lucerne plants from dwarfs to giants, and then they are able to contend with, if not conquer, so strong plants as sainfoin are, though before plough- 
ing they were unable to resist the depredations of a few lazy spires of grass.

"Since tillage can thus recover lucerne, after it has long languished in the lowest ebb of life, and restore it to health, youth, and vigour, and augment its stature even after it has passed the age of its full growth, to what bulk would it arrive regularly planted, and hoed from its infancy to maturity, without any check to stunt it?"

Sowing.- Sowing is generally performed in the Midland and Southern counties in April, being frequently sown in drills varying in space 12,15 and 18 inches apart, as well as broad-cast. From fifteen to twenty pounds per acre of seed is usually sown.

Hoeing.- The greatest attention should be paid to keeping the ground clean by effectual hoeing and thorough destruction of weeds and grass.

Tull, ${ }^{1}$ who paid great attention to the growth of lucerne, and who has left on record some very interesting particulars and records of experiments, says :-

"The well-hoed earth being open, receives and retains the dews; the benign solar influence is sufficient to put them in motion, but not to exhale them from thence. The hoe prevents the turf, which would otherwise by its blades or roots, intercept and return back the dews into the atmosphere, with the assistance of a moderate heat, so that this husbandry secures lucerne from the injury of a wet summer, and also

1 English husbandry is greatly indebted to Tull, who advocated thorough pulverisation of the soil ; but he was ignorant of the fact that, its increased fertility was not due to mere submission, but to the admission of air and water, which contain the organic elements of vegetation, Hydrogen, Carbon, and Ammonia, though a glimmering of the fact seems here to have occurred to him,-[Ed.] 
causes the rain-water to sink down more speedily, and disperse its riches all the way of its passages ; otherwise the water would be more apt to stand on the surface, chill the earth, and keep off the sun and air from drying it. For when the surface is dry and open, lucerne will bear a very great degree of heat, or grow with a mean one. I have seen this hoed lucerne in a sheltry place of my garden so much grown in a mild winter as to measure fourteen inches and a half high at Christmas; and a very large single plant of it, which had not been hoed for two years before, was laid bare by digging out the earth all around it a foot deep, to observe the manner of its tap-root; and then the earth was thrown in again, and the hole filled up. This was on the 29th of September. Upon this mellowing of the soil about it, it sent out more stalks in October than it had done the whole summer before. They grew very vigorously until a great snow fell in December, which also preserved the verdure of them until that was melted away, and a bleak frost came after it and killed those stalks. It is probable this plant sent out immediately new fibrous, horizontal roots, which did grow apace to extract the nourishment from this new-made pasture, in proportion to the quick growth of the stalks, which in summer have been measured, and found to grow in height three inches and $a$ half in a night and day; this being almost one inch in six hours."

Harvesting.-Lucerne is made into hay in the same way as sainfoin when it is so treated, but, as we have before stated, the crop is generally consumed for soiling cattle. Upon the prospect of rain when it has been cut, and there has been an abundance of straw, 
it has sometimes been stacked while yet in a very green state, with alternate layers of dry oat-straw, which has prevented it from heating, and has communicated to the straw that flavour which is so palatable to horses when cut into chaff, from the slight fermentation which has ensued, and which the straw has absorbed.

Mildew in Lucerne,-Lucerne is subject to mildew which, when it attacks the plant, changes it from a light green colour to almost a dirty white, and caterpillars attack it in swarms, commencing with the top tender shoots, and eating it downwards till the leaves are all stripped off. In such a case it is best to cut it down at once, and allow the plant to spring up afresh.

Wide-standing Crops of Lucerne.-Lucerne is sometimes planted in drills six feet asunder, with crops of cabbage, carrots, \&c., in the intervening spaces, in which the quick progress of lucerne, as in the instance given above, is very remarkable. Tull, in one instance adduced, says:- "I have one single lucerne plant in a poor arable field, that has stood the test of two-andtwenty winters, besides the feeding of sheep at all seasons, and yet remains as strong as ever. What quantity of hay this plant yearly produces cannot be known, because at those times that cattle are kept from it, the hares constantly crop it, being sweeter than any other grass. But this happens to be fortunately situated, where it is not altogether destitute of the benefit of hoeing. It is in an angle, where, every time the field is tilled, the plough goes over it in turning from the furrows of one land and one head-land, but it is after the plough is lifted out of the ground and turned up on one side, so that the share only breaks 
the turf very small all round it without ploughing up the plant; yet it has escaped it so narrowly, that the fin of the ploughshare has split it into four parts, three of which remain, and grow never the worse, but the fourth is torn off, and the wound healed up."

Tull further goes on to say:- "It must likewise be observed, that the crop will be produced in proportion to the nourishment it receives; for if the most gigantic lucerne-plant, which, when pampered by the hoe, has made a produce more like a tree than an herb, remains a few years without that or some equivalent culture, it will by little and little cease to produce more than a few poor sickly stalks, just to show its species, and then, if this culture be repeated, it will recover its pristine strength and yield as great a crop as ever; but if that be longer omitted will die; the vastness of its roots avails nothing unless it has food in proportion to it.

"Hence it appears that the most fatal disease incident to lucerne is starving, and that rarely suffers any of its plants to arrive at the full period of their growth or age; it prevents their fertility even in the prime of their youth, and kills them even before they have lived out half, or perhaps the tenth, part of their days; how long this life might otherwise be nobody knows, unless a plant could be found to die when well fed; for when it is, it is so tenacious of life that I am told beheading will not despatch it."

Liability of Cattle to swell from eating Lucerne.As cattle will at the first outset eat lucerne greedily, care must be taken not to give them too much at once till they are accustomed to it.

The swelling only occurs to such animals as chew 
the cud, and most farmers know how to guard against this evil. But sometimes an animal by accident has strayed to growing lucerne, and has partaken of more than was good for it. In such a case, to prevent the animal from being choked, from the air pressing the lungs against the thorax so closely, a hole is cut in the maw near the back, when the air rushes out and saves the beast.

Lucerne eaten by Fly.-Lucerne plants should stand till they become fairly grown before they are singled out with the hand hoe, for lucerne is sometimes eaten by the fly in the same way that turnips are attacked, and this may make all the difference in the number of plants required.

The analysis of the ashes of Lucerne shows as under :-

\begin{tabular}{|c|c|c|c|c|c|c|}
\hline Potash & $\ldots$ & $\ldots$ & $\cdots$ & $\cdots$ & $\cdots$ & $14^{\circ} \mathrm{O}_{3}$ \\
\hline Soda & $\ldots$ & $\ldots$ & $\ldots$ & $\ldots$ & $\ldots$ & $6 \% 44$ \\
\hline Lime & $\ldots$ & $\ldots$ & $\ldots$ & $\ldots$ & $\ldots$ & 50.57 \\
\hline Magnes & & $\ldots$ & $\ldots$ & $\ldots$ & $\ldots$ & $3 \cdot 64$ \\
\hline Oxide o & of iron, & alun & , \&c. & $\ldots$ & $\ldots$ & 0.63 \\
\hline Phosph & oric acio & & ... & $\ldots$ & $\ldots$ & 13.68 \\
\hline Sulphur & ric acid & $\ldots$ & $\ldots$ & $\ldots$ & $\ldots$ & 432 \\
\hline Chlorin & & $\ldots$ & $\ldots$ & $\ldots$ & $\ldots$ & $3 \cdot 23$ \\
\hline Silica & $\ldots$ & $\ldots$ & ... & $\ldots$ & $\ldots$ & 346 \\
\hline
\end{tabular}




\section{CHAPTER XI.}

\section{SAINFOIN.}

General Remarks-Great Length of Sainfoin Roots-Preparation of the Land for Sainfoin-Sowing-Making Sainfoin Hay-Table of Acreage under Cultivation in Great Britain and Ireland-Analysis of Sainfoin Ashes.

GENERAL REMARKS.-We are indebted to the French for the introduction of sainfoin, i. e. "holy hay," otherwise Sanctum Fonum, though the precise date of its introduction is unknown ; but it was mentioned by Aubrey more than two hundred years ago, and has sometimes been called "Everlasting Grass" from the fact of its lasting so long, some of it having been known to stand for forty years.

It is safer to feed cattle with, than either clover or lucerne in its green state, as it does not cause them to "hove" or swell, and possesses some peculiar characteristics which distinguish it from the other artificial grasses. Several species of sainfoin are described by botanists, though there is but one kind which is familiarly known to farmers.

The hay is made into four kinds : first, that which is cut before the plant has began to blossom ; second, that which is in blossom; third, the full grown; and finally, the thrashed hay. Of these the first makes incomparably the best hay. It thrives best on calcareous soils, and can be made to grow on either poor 
or rich land after a different manner, and for different reasons. On poor lands the first crops are always light, but on rich land they are the heaviest, the theory of which we will briefly endeavour to explain. Having a tap root, where it is grown upon a chalky base, the roots will extend to it, and pass through the insterstices of the soil to a very great distance.

Great Length of Sainfoin Roots.-The tap root descends deep down into the earth, having horizontal ones attached to it, which are longer near the surface and diminish as the perpendicular one descends lower, and pieces of root have been broken off in a pit which measured fourteen feet in length, and it is said they will descend as low as twenty or thirty feet where there is sufficient opening for them to extend themselves. The consequence is (without requiring the root to attain such extreme length), the plant derives much sustenance from its root which it sends so far for nourishment, and sufficient time must be allowed in poor soils for this to grow sufficiently large. A porous soil is therefore much better adapted for its growth than a strong retentive clay soil. At the same time a naturally good soil will produce a heavy crop of sainfoin without manure, and the herbage grow much more rapidly upon a greater number of smaller plants, and the quality of the crop will be doubtless better; and this will be especially the case on rich sandy soil, where the growth of small plants would be rapidly stimulated, and the crop become heavy from the multiplicity of leaves from a smaller growth of herbage, rather than from the development of larger plants.

Preparation of the Land for Sainfoin.-Sainfoin being often sown at the close of an alternate system 
of cropping, when it is intended to sow with barley it is customary to get it well cleaned and in good preparation, by having a crop of turnips well hoed, and folded off as a commencement of operations, in anticipation. This being done late in the autumn, the land is ploughed up and left rough. In January it is harrowed down, and afterwards ploughed deeply, as if the intention were to plant a crop of carrots. The first week in March it is run over with scufflers or harrowed again, and about the middle of April the barley is sown thin and harrowed, after which the sainfoin is sown broadcast in the same manner as clover, and afterwards lightly rolled. As it is necessary that the crop should be free from grass, which is apt to choke the sainfoin when sheep are put upon the land beforehand, care should be taken to supply them with hay which has been cut before the seed has formed, otherwise it will be detrimental to the future crop.

Sowing.-From three to five bushels of seed are generally used, four being the most common quantity, there being an enormous number of seeds in one bushel, but it is very precarious, and it is necessary to have a sufficient quantity to guard against contingencies.

In Malcolm's Modern Husbandry it is stated the number of seeds in a bushel of the usual quantity is about 871,200; an acre, if sown with four bushels, would therefore produce $3,484,800$ plants-a number which no land could sustain-being at the rate of about 21,700 to the square pole, and so to every square foot. Seventy-two heads have been known to proceed from one root, and if evenly and thinly sown will average ten heads. 
Others drill upon young wheat; and when the jand is in good condition with a fine surface there is a tolerable certainty of a crop. Cleanness of soil, however, is the most essential point to observe.

Some farmers add trefoil or rye-grass to make sure of a crop the first season, but this is not desirable. Tull, who was always experimenting, says, " The worst crop that can be sown amongst sainfoin is clover or rye-grass ; barley or oats continue but a little while to rob it, but the other artificial grasses rob it for a year or two, until the artificial pasture is near lost; and then the sainfoin never arrives to half the perfection as it will do when no other grass is sown amongst it.

"The injury these hay-crops do to the sainfoin is best seen where some parts of the same field have them, and the other parts are without them.

"When barley, among which the sainfoin is planted in a dry summer, is great, there are few farmers that know till the next spring whether the sainfoin succeeds or not; because the young plants are not then visible, unless it be to those who are accustomed to observe them in all the degrees of their growth. I have seen a field of ten acres of such, wherein after the barley was carried off nothing appeared like sainfoin, but when, by the print of the channels I searched diligently, I found the small sainfoin plants thick enough in the rows; they had no leaves, they being cut off by the scythe no part of them that was left had any green colour; but from the plants there came out many sprigs like hog's bristles, or like the beard of barley; this whole piece of sainfoin succeeded so well that the third year its crop was worth three pounds per acre, the land being good." 
When this was written, the value both of money and produce was very different to that of the present day, money being worth more, and produce less than at present.

Making Sainfoin Hay.-It is generally cut when in full bloom, and treated in much the same manner as clover. As the latter is often over-made, so in making sainfoin this error must be avoided, for its perfection consists in retaining the natural appearance of the blossom, and the growth of the stem and leaves. Ordinary grass is generally exposed as much as possible to the rays of the sun, and the swaths are turned over quickly to derive all the benefit of their influence. This should not, however, be done with sainfoin. While the sun is very hot the swaths should be moved as little as possible, or the leaves, which is the best part, will become too much dried. In point of fact everything is better when well dried in the shade, though this is not generally understood, for plants retain more of their natural properties than when dried in the sun, but in the business of husbandry, time is the first consideration when there is a large amount of work to be got through. But this must not be overlooked in the case of sainfoin, and without being at all difficult to get in, it requires a good deal of judicious drying. Rain hurts it very much both in colour and quality. If there is any risk in heating, layers of straw placed in the stack in the same manner as described with lucerne, will be found a good plan, and an agreeable flavour will be communicated to the straw which the cattle relish very much.

Much drying is necessary from its natural succulency, and from its having hollow stems, so that time, 
if it can be given to it, is better than the heat of the sun when extreme.

The cocks can be made larger than in common hay, as by the smaller degree of flexibility of the stalks they will remain longer without fermenting. If spread thinly on the ground in hot weather, which is often done for the purpose of thoroughly drying it, its juices will get exhausted, and the quality much deteriorated. Rather than increase the number of cocks, it will be found better to shake the hay lightly while undergoing the process, and diminish the number of cocks by making them into fewer large ones. On the contrary, when built into ricks they should be small, with a chimney in the centre, through which the superfluous moisture may exude.

Sainfoin for Seed.-The management of sainfoin when saved for seed is somewhat difficult on account of the pods ripening at different intervals, and the best time to choose for cutting will be found by examining the condition of some of the first blown, which will be dead ripe before the bulk of the crop is fit for the scythe, which will be indicated by beginning to turn to a brownish colour, while the pods feel plump and firm.

On the deep hard loams which lie along the edge of the chalk cliffs in some of our southern counties no manure is thought necessary, and dung is never given by the most experienced farmers, and when manure is applied it is generally in the form of a top-dressing consisting of peat, turf, or coal-ashes. About 30 bushels of the latter are given to the acre, having a less tendency to bring on the plant quick, the manure for dressing sainfoin being chosen for the reverse properties 
that are looked for when applied to other crops, so as not to cause it to come too suddenly forward.

Gypsum is sometimes used at the rate of five bushels per acre, but on all soils, even the very poorest, the top-dressing is always light.

The analysis of the ashes of sainfoin both in flower and seed are given as under :-

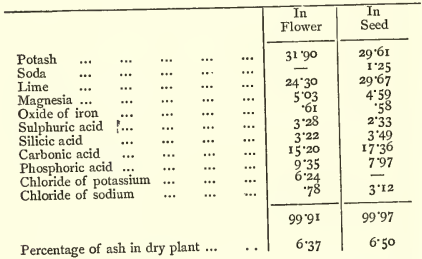

The comparatively large amount of artificial grass which is cultivated in the United Kingdom will show that these are highly approved by agriculturists, as may be seen from the accompanying table. We give the whole average of various kinds of crops under cultivation, which will be found interesting as showing at a glance the quantities of each.

TOTAL AREA AND ACREAGE under each kind of Crop, Bare Fallow, and Grass, as returned upon the 4th June, 1877 , and $25^{\text {th }}$ of June in 1876 , in each division of Great Britain, with similar particulars for Ireland, and with total for United Kingdom :- 
ACREAGE UNDER CROP.

Total Area and Acreage under Corn Crops, Green Crops, Bare Fallow, Grass, \&c.

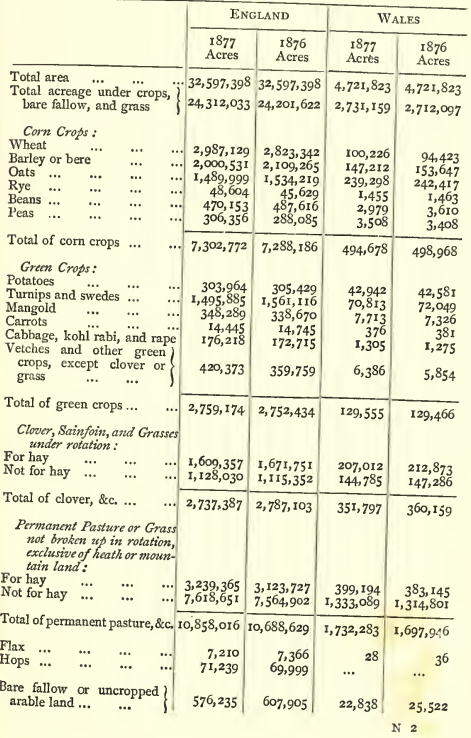


Total Area and Acreage under Corn Crops, Green Crops, Bare Fallow, Grass, \&c.

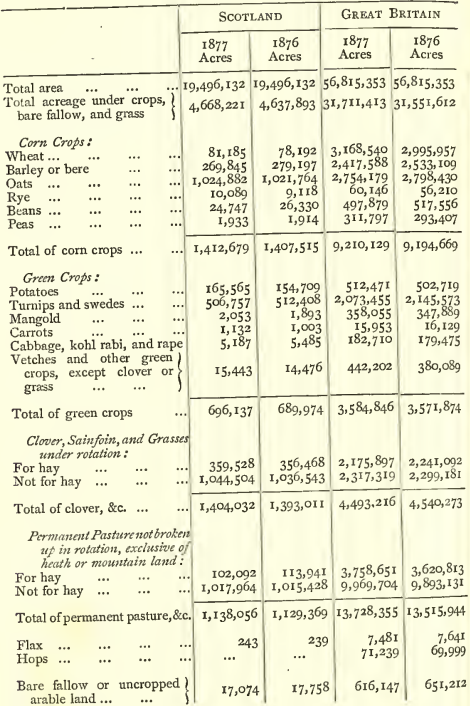


Total Area and Acreage under Corn Crops, Green Crops, Bare Fallow, Grass, \&c.

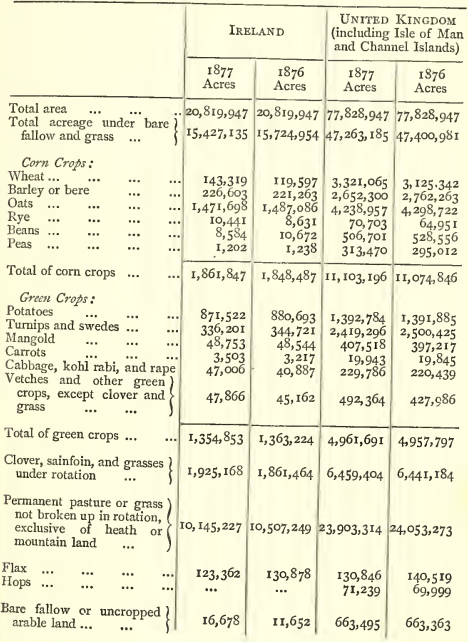


There is a variety of sainfoin which is called by the French "sainfoin à deux coupes," which is cultivated to some extent in France, and also the giant sainfoin, which produces a greater quantity of leaf; but in this country the ordinary kind is the species universally cultivated.

Sainfoin is seldom cut a second time in the same year, the after-grass being generally pastured by cattle and horses. It is therefore not liked so much by many farmers as Lucerne. Sheep are very fond of it, but it is not generally considered expedient to put them on it, from the apprehension that they will crop it down so close as to expose the roots to the frost. The deep roots, as we have seen, cannot well be reached by it. 


\section{CHAPTER XII.}

TARES.

Varieties-Application of the Crop-Sowing-Tares for Hay-Growing Tares for Seed-Analysis of the Ashes of Tares-Rye-grass-Sowing-Rye-grass as Food for Stock-General Remarks-Analysis of the Ashes of Rye-straw-Rape and Cole-Affinity-Rape upon the Wolds of Yorkshire-Soil most Fitted for Rape-Sowing-Use of the Crop-Cole-Cultivation in Flanders-Seed-Mustard-Treatment while Growing-As Food for Sheep.

VARIETIR.S.-Tares, or vetches as they are indifferently called, are known in the form of several varieties, and are of one species according to some botanists, but strictly speaking they are distinct plants. The kinds ordinarily cultivated are the spring and winter tares, the names of which owe their distinctiveness to the fact of being more or less hardy, and their time of ripening.

"The broad-leaved vetchling" or "everlasting tare" is sometimes cultivated in gardens for the sake of its flowers, and there are the "white tare," the "strangle vetch," the " tufted " and "wood vetch;" but "winter tares" and "spring tares" are the only kinds ordinarily noticed by agriculturists, though the "everlasting tare " or "broad-leaved vetchling" is said to bring large crops of a superior quality.

Application of the Crop.-The. seed of the tare, which resembles the pea very much, is frequently given as food for pigs; but the chief application of vetches is for soiling purposes; for although it makes capital 
hay, there is some little difficulty in getting it into stack, while it is most serviceable to all kinds of stock. Sheep do better upon tares than upon any other kind of herbage, and it is therefore held in high esteem by pedigree ram-breeders. Horses improve upon it more rapidly than upon any other of the artificial grasses. Cows, it is said, yield more butter when fed upon tares, while pigs eat it greedily when in its green state, and thrive upon it without farinaceous food.

Sozving.- Spring tares can be sown during the months of March and April, or even later, should there be occasion to do so, up even to the end of June, being not unfrequently made to follow a crop of winter tares. According to the Sussex Report, "on the South Downs it is a common practice to sow forward winter tares, which are fed off late in the spring with ewes and lambs; they then plough and sow summer tares and rape $-2 \frac{1}{2}$ bushels of tares and half a gallon of rape-and this they feed off with their lambs in time to plough once for wheat."

The method of preparing the land for the seed is to plough it four and a half to five inches in depth, and then to harrow it fine, and sow the seeds in drills. When there is sufficient time to do so, it is better to have the land ploughed in winter, and then crossploughed and made thoroughly clean, and afterwards rolled. Spring tares produce rather a lighter crop than winter tares. Winter tares are often sown upon a wheat stubble with the intention of being either soiled or left to stand for a crop of hay. The time for sowing winter tares is from the beginning of October till the middle of November. They will stand very severe weather, and when they once com- 
mence to grow in the spring they make rapid progress and come in very early for use.

If the soil is rich and in good heart there is scarcely any need of manure, but a top-dressing of guano in the spring will be found very efficacious.

Tares for Hay.-If it is designed to make hay of them, which is not, as a rule, very often done, the crop should be left standing till the flowers have given place to the pods, and some of the seeds get definitely formed. After cutting, the swaths should be lifted as lightly as possible and shaken apart, and dried as quickly as can well be, for if it gets thoroughly wetted it is a very awkward crop to deal with, and becomes injured more than any of the other artificial grasses. It makes coarse hay, which will produce about three tons to the acre on average land.

Growing Tares for Seeds.-When grown for seed the common practice is to drill both spring and winter tares in the same way that peas are managed. The results are often very precarious, and sometimes, although a heavy crop may be grown, there will in the end be found not much more than the quantity of seed sown, and the haulm being exceedingly tough, is in some instances merely used as fodder, so that one of the otherwise most profitable crops will turn out a very unprofitable one. On the other hand, when secured well, the crops have reached forty bushels per acre. This will of course much depend upon how the crop is secured, for rain makes sad havoc with it, for the necessity of frequent turning and drying it, opens the pods, when of course a good deal of the crop becomes lost. If a few beans are dibbled in the rows, they afford a good deal of support to the crop, which when 
ripe can be easily separated by the riddle from the tares. Nearly all the pods should be fully ripened before mowing.

According to Schwertz, air-dried tares show on an average :-

$$
\begin{array}{lllllll}
\text { Seed } & \ldots & \ldots & \ldots & \ldots & \ldots & 30 \\
\text { Straw } & \cdots & \cdots & \cdots & \cdots & \cdots & \frac{70}{100}
\end{array}
$$

Analysis of the Ashes of Tares.

\begin{tabular}{lccccr} 
Potash $\ldots$ & $\ldots$ & $\ldots$ & $\ldots$ & $\ldots$ & $35 \cdot 28$ \\
Lime $\ldots$ & $\ldots$ & $\ldots$ & $\ldots$ & $\ldots$ & $38 \cdot 33$ \\
Magnesia & $\ldots$ & $\ldots$ & $\ldots$ & $\ldots$ & $6 \cdot 35$ \\
Silicic Acid & $\ldots$ & $\ldots$ & $\ldots$ & $\ldots$ & $8 \cdot 66$ \\
Chloride of Sodium & $\ldots$ & $\ldots$ & $\ldots$ & $2 \cdot 67$ \\
Alumina & $\ldots$ & $\ldots$ & $\ldots$ & $\ldots$ & $\cdot 29$ \\
Oxide of Iron & $\ldots$ & $\ldots$ & $\ldots$ & $\ldots$ & $\cdot 18$ \\
Protoxide of Manganese & $\ldots$ & $\ldots$ & $\cdot 16$ \\
Phosphoric Acid & $\ldots$ & $\ldots$ & $\ldots$ & $5 \cdot 49$ \\
Sulphuric Acid ... & $\ldots$ & $\ldots$ & $\ldots$ & $2 \cdot 39$ \\
\hline
\end{tabular}

Rye-grass. - In another place I shall treat upon rye as a grain, which is frequently grown upon light soils, but I am now dealing with it as a green crop, and it is alike useful both as pasture and hay, as well as for soiling, for which it is most commonly used. As hay, horses are said to preserve their wind upon it better than any other description, and all cattle are fond of it in either form. Its chief value, however, lies in its quick and early growth, and it can be grown upon soils which would yield but a small return if clover were sown. It is sometimes sown with clover, which it is found not to choke whilst in the first stages of its growth, and in the second, it keeps ahead of it, producing hay little inferior in quality to the first 
It comes in well for lambs and sheep after the turnips have been used up, and is peculiarly well suited to all animals giving milk.

Sowing.-It is generally usual to sow rye very thickly which is intended to be used in its green state; three to three and a half bushels per acre being commonly used. It is generally sown upon root fallows, and is often followed by white turnips. The seed is either drilled or sown broadcast. A few tares or rape seeds are sown with the rye to improve the bottom herbage.

Rye-grass as Food for Stock.-Green rye is very laxitive in its nature, and the best way of using it in the first place, especially in the case of horses which have been fed for a long time upon dry feed, is to cut it into chaff with a mixture of straw or hay, increasing the green food as the season advances. One-third green should be given in the first place, then advance to half, and finally, reversing the proportions, leaving off with two-thirds green and one-third dry food. This progressive change will be found of great service in effecting the gradual substitution of green food in place of dry, upon the annual recurrence of the different seasons, and no risks are run of animals "hoving." The great advantage of the crop lies in its coming so early into use.

Sheep are usually folded off on rye, a fresh piece being divided for them daily, and the hurdles so placed as to allow the lambs to pass through and eat the fresh rye-grass that will come next in succession, whenever they show a disposition to do so. The time for doing this will much depend upon whether the winter has been mild or severe; but if it is allowed to 
get too forward, the sheep will not eat it readily, but it is usually fit for use from the middle of April to the end of that month.

General Remarks.-In the form of a perennial grass it lasts from three to six years, and may be grown upon almost any kind of soil that is not very stiff and strong; but when the kind known as "annual ryegrass" is used, which in reality is a biennial, and grows a heavier crop than the perennial, in the year after being sown, it is generally employed when intended to break up the land after a crop of hay has been secured.

The following is the analysis of the ashes of ryestraw :-

$$
\begin{aligned}
& \begin{array}{lllllll}
\text { Potash } & \ldots & \ldots & \ldots & \ldots & \ldots & \mathbf{1 7} 7 \mathbf{1 9}
\end{array} \\
& \begin{array}{llllll}
\text { Magnesia } & \ldots & \ldots & \ldots & \ldots & 2^{*} 4 \mathrm{I}
\end{array}
\end{aligned}
$$

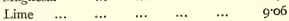

$$
\begin{aligned}
& \begin{array}{lllll}
\text { Phosphoric Acid } & \ldots & \ldots & \ldots & 3.82
\end{array} \\
& \begin{array}{lllll}
\text { Sulphuric Acid ... } & \ldots & \ldots & \ldots & .83
\end{array} \\
& \begin{array}{llllll}
\text { Silicic Acid } & \ldots & \ldots & \ldots & \ldots & 64.50
\end{array}
\end{aligned}
$$

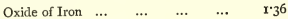

$$
\begin{aligned}
& \begin{array}{lllll}
\text { Chloride of Sodium } & \ldots & \ldots & \ldots & -57
\end{array} \\
& \text { Chloride of Potassium ... } \quad \ldots \quad \ldots \quad \ldots \quad .26 \\
& 100 \div
\end{aligned}
$$

\section{RAPE AND COLE.}

Affinity.-Rape and cole resemble each other so closely, that, for the purpose of making cake, one is much the same as the other in all material points, yet, grown to be used as green food for cattle, their properties will be found different, inasmuch as rape will grow upon a poorer soil than cole, though an absolutely poor soil is not fitted for either; but rape will suit adliesive land which is too close in its nature for turnips, being cultivated in the same manner; and it 
is found also useful as a change to turnips, as a kind of tonic for the land. It is in the close observation of these and similar particulars that successful farming consists, which, unfortunately, are generally too much overlooked, and by which a more profitable return may be gained. Rape is capital food for sheep, while it can be sown later in the season, and also ripens earlier than cole. It begins to send out its shoots soon in the spring, and continues to grow very late in the autumn, a great deal of nutriment being contained in the abundant pith with which the stalk abounds, which the sheep consume in preference to the leaves. It is also considered one of the best manures to be ploughed in while standing as a green crop-a practice, however, which of late years has been somewhat on the decline.

Rape upon the Wolds of Yorkshive.-In a Report which has been published on "Farming at Wauldby, upon the Wolds, in the East Riding of Yorkshire," the following description is given of the method of cultivation of rape pursued there:- "A portion of the fallowed lands have for the last few years been sown with rape, solely for the use of the sheep; it is cultivated in drills twelve inches apart, but not thinned in the rows, though well hoed between them. The quantity of seed used is $4 \mathrm{lbs}$. per acre. To afford a regular succession of food, it is sown at three different periods, between the middle of May and the end of June, and the sheep are put upon it three months after it has been sown. A considerable quantity of the very best food is thus raised, to come in at a period when it is most wanted, viz., when the freshness of the clover and grass leys is on the decline, and before the turnips are 
fully grown. It is considered equally valuable for the lambs when taken from the ewes, and for the shearing wether sheep, eighteen months old, which are at that period nearly fat, and require food of the most nutritious quality. The land is afterwards sown with wheat, and the crop is usually considerably heavier than it is after turnips, or after any other preparation of Wold land for wheat."

Soil most fitted for Rape.-As before stated, land which is considered too stiff to suit turnips well, is adapted for rape, which is peculiarly fitted for alluvial, or rich clay soil. It flourishes in a remarkable degree upon land which has remained a long time in grass, upon which it may be seen growing to the best advantage. When grown for the purpose of raising seed in the fens of Cambridgeshire and Lincolnshire, the yield has been known to reach from five to six quarters per acre, though under ordinary conditions, half that amount of produce is considered a fair crop.

Sowing.-Rape is frequently sown broadcast, but the best plan is found to sow in drills of a sufficient width to allow of the horse-hoe being used, or at all events of allowing them to be well hand-hoed if planted on small patches. The drills will therefore vary from twelve to twenty-six inches apart, and the plants should be cut out with the hoe to stand from six to twelve inches asunder in the rows. By this means weeds can be easily kept under. Those who sow it broadcast upon a fallow generally use about three quarts of seed to an acre, in the month of June, and trouble themselves very little about it afterwards, which used to be the old-fashioned method of treating the crop, neither hand-hoeing nor weeding it. It is 
sometimes sown in August as spring food for ewes and lambs, but the crop is but a poor one, being more disposed to flower than throw out strong stems or leaves. When allowed to stand too thickly upon the ground, it does not succeed so well, and the stems are small and hard, destitute of that amount of succulence which is obtained by the plant in an eminent degree from free circulation of the air, absorbing from the atmosphere those constituents which foster its properties and growth.

Use of the Crop.-If the plants are well developed and grown on good land which has allowed the plant to flourish in full luxuriance, sheep will fatten upon it more quickly perhaps than upon anything else. As food for them in the months of August, September, and October, the crop often comes in very useful, but it is necessary at that late period to use it up immediately it has reached maturity, otherwise the leaf commences to decay, and it falls a victim to the early frosts.

Rape abounds with flesh-forming constituents when the plant is at its best, being richer in fatty compounds than cabbage.

It has fewer enemies than most other crops, not being subject to insect depredations, while it stands variations of the weather without sustaining any perceptible amount of injury.

\section{COLE.}

Cole is very often confounded with rape, as before stated, even by otherwise very accurate writers upon agricultural subjects; but the flowers of the plant are of a clearer and brighter yellow than those of rape, 
while its stem is also stronger. Both the pods are larger, and the seeds which are contained in them, than rape.

Cultivation in Flanders.-In Flanders, Belgium, and other parts of the Continent the plan of cultivation most generally followed is by transplanting the plants like cabbages, by which means, while the young produce is growing, another crop may be standing on the ground which these are ultimately destined to occupy. The manure usually consists of a large quantity of bruised rape, and eighteen cart-loads of night-soil to the acre.

The seeds are sown in August, or even up to the middle of September. At the end of September, in the case of the earlier sown seeds, the plants are dibbled out; and in the case of the late ones in October. In the middle of November they dig between the rows, and set up the clods, in order to shelter the plants as much as possible from frost and cold winds.

When put in by the plough, and not dibbled in, as by the former method, a furrow is made about eight inches in depth, in which manure is laid, upon which the plants are placed at intervals of about a foot, which are then covered upon the return journey of the plough.

When planted upon a corn stubble they are dibbled in the seams of the ploughing, the furrow-slice being twelve inches broad, the plants being set at intervals of a foot in the rows.

Rape-dust is often thrown into a liquid manure tank, by which means it becomes partially decomposed, and is therefore more efficacious in its operation, and is found much more fertilizing than when used in 
its dry condition. Immediately after the frost has gone, the intervals are weeded, and hand-hoed, and again in April, which is all the attention the crop receives until harvest. The crop is pulled rather green, and is allowed to complete its ripening in the stack, the seed being thrashed out in the usual manner that is generally followed.

Seed.-When cole is intended to be saved for seed, a richer soil is needed than for rape, and on rich land the seed for these crops should be sown from the middle of July to the middle of August, so as to give them a long time to ripen in the ensuing summer. Should weeds spring up early in the autumn, the crop should be mowed off lightly, which will not be injured by having the tops cut off, which will be readily eaten by stock, if they are not allowed to eat it off the land, from not being sufficiently advanced to carry them; but no stock should ever be left on it after January. The crop is somewhat an exhausting one, and the land if not naturally rich will require plenty of manure ; for although not required upon maiden fens, or rich broken-up pastures, without manure both the crop will be poor and the land impoverished.

\section{MUSTARD.}

There are two kinds of mustard, which, although of a very similar nature, are yet distinct species-the white and the brown mustard, the latter being that from which the condiment familiar to us at our tables is made. One is of a whitish yellow, while the other is dark brown. The white mustard has prickly pods, while the brown are smooth. Both alike produce good oil when expressed from their seeds, which are 
brought to maturity only on a limited area of land, and that chiefly concentrated in certain districts, the most common practice being to grow white mustard as forage for sheep. The brown is the hardier of the two, and is often sown in February, but the white is much more delicate, and a frosty night will sometimes kill it, and it is therefore a very risky crop to grow if sown too early. It is not commonly sown till the end of March or beginning of April, or sometimes even in May, and later yet.

Soil.-Both kinds require a good rich soil, more especially the brown, and the land should be thoroughly well worked fit for the reception of the seed. The strong-land hundreds of Essex have been found very suitable for the growth of brown mustard, and also for a length of time in Faulness and Wallasea Islands, and in the West Riding of Yorkshire close to the river Ouse; in Lincolnshire, Norfolk, and Cambridgeshire.

The white kind, however, succeeds upon light loams, upon which good crops are often raised, and it is sometimes planted after wheat, but when put in late it is subject to the attacks of caterpillar and the fly. Almost any kind of soil will grow white mustard, and the custom of sowing it has rapidly extended of late years, being made to take the place of root crops which have turned out failures; and it profitably fills up the void that sometimes occurs after early peas, or as a second crop after vetches, when, from the season being advanced, nothing else can be grown to advantage. When sown after wheat the land requires to be got in good order, and well manured.

Sowing.-About one peck of seed per acre is 
generally used, which is thrown broadcast upon a well-harrowed surface. The crop will attain its full growth, if sown early, in six or seven weeks, but if sown late, it takes a longer time to reach an adequate maturity. Mustard is said to have a useful effect in clearing the ground from wire-worm, the insect having a great antipathy to the plant. Some people use as much as a peck and a half of seed, but the plants should stand out at a distance of about ten inches from one another.

Treatment while Growing.-Almost every plant thrives better when the soil is well stirred all round it. This, however, is not the case with mustard, which, having a long taper root, succeeds better when left alone. The crop should be hoed in May to keep it clear of weeds, and if the plants are strong and vigorous they should stand rather thin. If grown with a view of being fed off, the stock should be put on it a week before the time of its coming into blossom, when the whole can be eaten in due time in perfection before the stems get old and woody.

Ploughed in, as a green crop, mustard has been found very efficacious as a manure, and six or eight bushels of wheat per acre more have been got from its use than where the land was cake manured. When this is done, the crop should be ploughed in before it has blossomed, as the flowering exhausts the land. The crop is said to be a very exhaustive one, but this applies to the brown rather than the white species.

As Food for Sheep.- Sheep when fed upon mustard alone, although they keep healthy, do not make much progress towards fattening, and it is considered the best plan to let them run on the pasture land during 
the day, and fold them at night upon the mustard, if the land is suitable for autumn folding; which is found both an economical and effective preparation for a wheat crop. Rape, however, ought to be sown, and not cole, when the intention is solely to provide food for sheep, with which view rape, cole, and mustard are commonly cultivated in this country. The former and the latter only, however, need to be held in remembrance for this purpose, but $I$ have thought it worth while to point out the distinction which exists between rape and cole.

[The Publishers are indebted to Messrs. Sutton \& Co. of Reading, who have kindly supplied the illustrations which accompany the present work.] 


\section{IT, HENRIETTA STREeT, Covent GARDEN, W.C. APRIL, I892.}

\section{A \\ Catalogue of flooks}

PUBLISHED BY

CHAPMAN \& HALL LIMITED.

A separate Ilustrated Catalogue is issued, containing Drawing Examples, Diagrams, Models, Instruments, etc., ISSUED UNDRR THE AUTHORITY OF

THE SCIENCE AND ART DEPARTMENT, SOUTH KENSINGTON,

FOR THE USE OF SCHOOLS AND ART AND SCIENCE CLASSES. 


\section{NEW AND FORTHCOMING BOOKS.}

A MIRROR OF THE TURF; or, The Machinery of Horse-racing Revealed, showing the Sport of Kings as it is to-day By Louis Henry Curzon. Crown 8vo.

FROM SINNER TO SAINT; or, Character Transformatlons: being a few Biographical Sketches of Historic Individuals whese Moral Lives underwent a Remarkable Change. By JoHs Burs BAlleY, Author of "Modern Methuselahs," Crown 8vo.

STUDIES AT LEISURE. By W. L. COORTNEY, Author of "Stndies Old and New," \&c. Crown 8ro.

SIBERIA AS IT IS. By H, Dr WindT, Author of "From Pekin to Calais," "A Ride to India," \&c. With an Introduction by MADAME OLGa Novixorf ("O. K.") With numerous Illustrations. Demy \&vo, IBs.

RUSSIAN CHARACTERISTICS. By E. B. LANIN. Reprinted, with revisions, from The Forinightly Roviow. Demy 8vo.

THE NATURALIST IN LA PLATA. By W. H. HODSON, C.M.Z.S., Joint Author of "Argentine Ornithology," With numerous Illustrations. Demy 8vo, $x 6 \mathrm{~s}$.

A HISTORY OF ANCIENT ART IN PERSIA. By GRORGES Prrrot and Charless Curptez. With 254 Engravings and 12 Steel and Coloured Plates. Royal 8vo, 315.

A HISTORY OF ANCIENT ART IN PHRYGIA-Lydia and Cerla-Lycia. By Georges Perrot and Charles Cumizz, With a8o Illustrntions. Royal 8vo, 15 .

TRAVELS IN AFRICA DURING THE YEARS 1879 to 1883 . By Dr. WilliAM Junkrr, Second Volume. With numerous Full-page Plates and Illustrations in the Text. Translated from the German by Professor KinNE. Demy 8vo, 215.

ON SHIBBOLETHS. By W. S. Lilly. Demy \$vo, I2s. ** Progress, Liberty, The Pcople, Prublic Opinion, Edwation, Womecn's Rights, and Supply and Demand.

MY THOUGHTS ON MUSIC AND MUSICIANS. By H. H. STAтHAM. Illustrated with frontispiece of the Entrance-front of Handel's Opera House and Musical Examples. Demy 8vo, 18s.

LIFE IN ANCIENT EGYPT AND ASSYRIA. By G. Maspéro, late Director of Arshaolosy in Egypt and Member of the Institute of France. Translated by A. P. Morton. With 188 mlustrations. Crown 8 vo, $5 \mathrm{~s}$.

AMONG TYPHOONS AND PIRATE CRAFT. By CAPTAIN LiNDSAY ANDERSON, Author of "A Cruise in an Opinm Clipper." With Illustrations. Crown 8vo, 5 .

AUSTRALIAN LIFE. By Francis Adams. Crown 8vo, 3s, 6d. ELINE VERE. By LOUIS COUPERUs. Translated by J. T. Groin. Crown 8vo, 5 s.

A PARTNER FROM THE WEST. By ARthur PATERson. Crown $8 \mathrm{vo}, 5^{s}$.

PRETTY MICHAL. By MAUrice JokäL. Translated by R, Nisbet Bars. Crown 8vo, 5 s. 


\section{$\mathrm{BOOKS}$}

PUBLISHED BY

\section{CHAPMAN \& HALL, LIMITED.}

ABOUT (EDMOND)-

HANDBOOK OF SOCIAL ECONOMY; OR, THE WORKER'S A B C. From the French. With a Biographical and Critical Introduction by W. Fraser Rar. Second Edition, revised. Crown 8vo, 4s.

ADAMS (FRANCIS)-

AUSTRALIAN LIFE. Crown 8vo, 3s. 6d.

AFRICAN FARM, STORY OF AN. By OLIVE SCHREINER (Ralph Iron). New Edition. Crown 8vo, $55 . ;$ in cloth, 15. 6d.

A NEW EDition, on Superior Paper, and Strongly Bound in Cloth, 35. 6d.

AGRICULTURAL SCIENCE (LECTURES ON), AND OTHER PROCEEDINGS OF THE INSTITUTE OF AGRICULTURE, SOUTH KENSINGTON, 1883-4. Crown 8vo, sewed, as.

ANDERSON (ANDREW A.)-

A ROMANCE OF N'SHABE: Being a Record of Startling Adventures in South Central Africa. With Illustrations. Crown Bvo, 5s.

TWENTY-FIVE YEARS IN A WAGGON IN THE GOLD REGIONS OF AFRICA, With Illustrations and Map. Second Edition. Demy 8vo, x25.

ANDERSON (CAFTAIN LINDSAY)-

AMONG TYPHOONS AND PIRATE CRAFT. With Illustrations by StakLzy Wood. Crown 8vo, 55.

A CRUISE IN AN OPIUM CLIPPER. With Illustrations, Crown 8vo, 6s.

ASTRONOMY (A NEW DEPARTURE IN). THE REVOLUTION OF THE SOLAR SYSTEM. By E. H. Demy 8vo, sewed, 2s. AVELING (EDWARD), D.Sc., Fellow of University College, London-

MECHANICS AND EXPERIMENTAL SCIENCE. As required for the Matriculation Examination of the University of London. MECHANICS. With numerous Woodeuts. Crown Bvo, $6 \mathrm{~s}$. Key to Problems in ditto, crown 8vo, $35.6 \mathrm{~d}$.

CHEMISTRY. With numerous Woodcuts. Crown $8 \mathrm{vo}, 6 \mathrm{~s}$

Key to Problems in ditto, crown 8vo, 2s. 6d.

MAGNETISM AND ELECTRICITY. With Numerons Woodcuts. Crown $6 \mathrm{~s}$.

LIGHT AND HEAT. With Numerous Woodcuts. Crown 8vo, 6s.

Keys to the last two volumes in one vol. Crown 8 vo, 55.

BAILEY (FOHN BURN)-

FROM SINNER TO SAINT; OR, Character TransFormations: being a few Biographical Sketches of Historic Individuals whose Moral Lives underwent a Remarkable Change. Crowa Bvo.

MODERN METHUSELAHS ; or, Short Biographical Sketches of a few advanced Nonagenarians or actual Centenarians. Demy 8ro, 10s. $6 \mathrm{~d}$.

$B E A T T Y-K I N G S T O N(W$.

A JOURNALIST'S JOTTINGS. 2 vols. Demy 8vo, $24 \mathrm{~s}$.

MY "HANSOM" LAYS: Original Verses, Imitations, and

Paraphrases. Crown 8vo, 35.6d.
THE CHUMPLEBUNNYS AND SOME OTHER ODDITIES. Sketched from the Life. Illustrated by KarL KLierscar. Crowa

A WANDERER'S NOTES. 2 vols. Demy 8vo, 245.

MONARCHS I HAVE MET. 2 vols. Demy 8 vo, $24 \mathrm{~s}$.

MUSIC AND MANNERS: Personal Reminiscences and Sketches of Character. 2 vols. Demy $8 \mathrm{vo}, 3 \mathrm{os}$. 
BELL (JAMES, Ph.D., \&־.), Principal of the Somerset House LaboratoryTHE CHEMISTRY OF FOODS. With Microscopic

Illustrations.

PART I. TEA, COFFEE, COCOA, SUGAR, ETc. Large crown 8vo, 2s. 6d. PART II. MILK, BUTTER, CHEESE, CEREALS, PREPARED STARCHES, ETc. Large crown 8vo, 35.

BRNSON (W.)-

UNIVERSAL PHONOGRAPHY. To classify sounds of Human Speech, and to denote them by one set of Symbols for easy Writing and Printing. Bvo, sewed, 15.

MANUAL OF THE SCIENCE OF COLOUR. Coloured Frontispiece and Illustrations. x2mo, cloth, 25. 6d.

PRINCIPLES OF THE SCIENCE OF COLOUR. Small 4to, cloth, $x 5$ s.

BIRDWOOD (SIR GEORGE C. M.), C.S.I.-

THE INDUSTRIAL ARTS OF INDIA. With Map and ${ }_{74}$ Illustrations. New Edition. Demy 8vo, 245.

BLACKIE ( $($ OHN STUART), F.R.S.E.-

THE SCOTTISH HIGHLANDERS AND THE LAND LAWS. Demy 8vo, 9s.

ALTAVONA : FACT AND FICTION FROM MY LIFE IN THE HIGHLANDS. Third Edition. Crown 8vo, 65.

BLEUNARD (A.)-

BABYLON ELECTRIFIED: The History of an Expedition undertaken to restore Ancient Babylon by the Power of Electricity, and how it Resulted. Translated from the French by F. L. WHITR, and Illustrated by MONTADER. Royal 8vo, x25.

BLOOMFIELD'S (BENJAMIN LORD), MEMOIR OFMISSION TO THE COURT OF BERNADOTTE. With Portrnits. 2 vols. Demy 8vo, $28 \mathrm{~s}$.

BONVALOT (GABRIEL)-

THROUGH THE HEART OF ASIA OVER THE PAMIR TO INDIA. Translated from the French by C. B. PItMan. With 250 Illustrations by AtBert PépIN. Royal 8vo, 32s.

BOWERS (G.)-

HUNTING IN HARD TIMES. With $6 \mathrm{I}$ coloured Illustrations. Oblong 4to, I25.

BRACKENBUR Y (COL. C. B.)-

FREDERICK THE GREAT, With Maps and Portrait. Large crown 8vo, 4s.

BRADLEY (THOMAS), of the Royal Military Academy, Woolwich-

ELEMENTS OF GEOMETRICAL DRAWING. In Two Parts, with Sixty Plates. Oblong folio, half bound, each Part $x 6 \mathrm{~s}$,

$B R I D G M A N(F . A)-$.

WINTERS IN ALGERIA. With 62 Illustrations. Royal 8vo, 10s. 6d. 
BRITISH ARMY, THE. By the Author of "Greater Britain," "The Present Position of European Politics," etc. Demy 8vo, ras.

BROCK (DR. 7. H. E.), Assistant Examiner in Hygiene, Science and Art Department-

ELEMENTS OF HUMAN PHYSIOLOGY FOR THE HYGIENE EXAMINATIONS OF THE SCIENCE AND ART DEPARTMENT. Crown 8vo, r...6d.

BROMLEY-DAVENPORT (the late W.), M.P.-

SPORT: Fox Hunting, Salmon Fishing, Covert Shooting, Deer Stalking. With numerous Illustrations by General CrzaLock, C. B. New Cheap Edition, Post Bvo, 3s. 6d.

BROWN (F. MORAY)-

POWDER, SPEAR, AND SPUR: A Sporting Medley. With Illustrations. Crown 8 vo, ros. $6 \mathrm{~d}$.

BUCKLAND (FRANK)-

LOG-BOOK OF A FISHERMAN AND ZOOLOGIST, With numerous Illustrations. Sixth Thousand. Crown $8 v 0,35.6 \mathrm{~d}$.

BUCKMAN (S. S.), F.G.S.-

ARCADIAN LIFE. With Illustrations by P. Buckman. Crown 8vo., rs.

JOHN DARKE'S SOJOURN IN THE COTTESWOLDS AND ELSEWHERE: A Series of Sketches, Crown $8 v_{0}, 1$ s.

BURCHETT (R.)-

DEFINITIONS OF GEOMETRY. New Edition. 24mo, cloth, $5 d$.

LINEAR PERSPECTIVE, for the Use of Schools of Art. New Edition. With Illustrations. Post 8vo, cloth, $7 \mathrm{~s}$.

PRACTICAL GEOMETRY: The Course of Construction of Plane Geometrical Figures. With 137 Diagrams, Eighteenth Edition. Post $8 \mathrm{vo}$, cloth, 5 .

BURGESS (EDWARD)-

ENGLISH AND AMERICAN YACHTS. Illustrated with so Beautiful Photogravure Engravings. Oblong folio, 425 .

BUTLER (A. \%.)-

COURT LIFE IN EGYPT. Second Edition. Illustrated. Large crown 8vo, r2s.

CAFFYN $(M A N N I N G T O N)-$

A POPPY'S TEARS. Crown 8vo, is. ; in cloth, is. 6d.

CARLYLE (THOMAS), WORKS BY.-See pages 29 and 30.

THE CARLYLE BIRTHDAY BOOK. Compiled, with the permission of Mr. Thomas Carlyle, by C. N. Wrumason. Second Edition. Small fcap. 8vo, 35 .

CARSTENSEN (A. RIIS)-

TWO SUMMERS IN GREENLAND: An Artist's Adventrres among Ice and Islands in Fjords and Mountains. With numerous Illustrations by the Author. Demy 8vo, r.4. 


\section{CHAPMAN \& HALL'S SHILLING SERIES.}

THE CHUMPLEBUNNYS AND SOME OTHER ODDITIES. Sketched from Life. By W. BeatTY-Kingston. Hlustrated by KarL Keietsch, Crown 8vo.

A SUBURB OF YEDO. By the late Theonald A. PUrcell. With Numerons Illustrations,

ARCADIAN LIFE. By S. S. BuCkman, F.G.S. With Illustrations, Crown Bvo.

- JOHN DARKE'S SOJOURN IN THE COTTESWOLDS AND ELSEWHERE. By S. S. Buckmak. With Illustrations.

SINGER'S STORY, A. Related by the Author of "Flitters, Tatters, and the Counsellor."

* A POPPY'S teArs By Mannington Caffyn.

+ NOTChes ON THE ROUGH EDGE OF LIFE. By Lynn Crall D'Orle.

* We TWO AT MONTE CARLo. By Albert D, Vandam.

* WHO IS THE MAN? A Tale of the Scottish Border. By J S. TAIT.

* THE CHILD OF STAFFERTON. By CANON KNox LitTLI.

- THE BROKEN VOW : A Story of Here and Hereafter. By CANow Kxox Litrut.

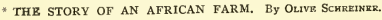

* paddy at home. By Baron E. De Mandat-Grancey.

* Bound in Cloth, Is. 6d.

CHARLOTTE ELIZABETH, LIFE AND LETTERS OF, Princess Palatine and Mother of Philippe d'Orléans, Regent of France, ${ }^{6} 5_{22-x} 22$. With Portraits. Demy 8vo, ros. $6 \mathrm{~d}$.

CHARNAY (DESIRÊ)-

THE ANCIENT CITIES OF THE NEW WORLD.

Being Travels and Explorations in Mexico and Central America, r857-r88z. With upwards of 200 Illustrations. Super Royal 8vo, 3rs. 6d.

CHRIST THAT IS TO BE, THE: A Latter-day Romance. Third Edition. Demy $8 \mathrm{vo}, 3 \mathrm{~s} .6 \mathrm{~d}$.

CHURCH (PROFESSOR A. H.), M.A. Oxor, -

FOOD GRAINS OF INDIA. With numerous Woodcuts. Small 4 to, 6 s.

ENGLISH PORCELAIN. A Handbook to the China made in England during the Eighteenth Century, as illustrated by Specimens chiefly in the National Collection. With numerous Woodeuts. Large crown $8 \mathrm{vo}, 3^{\mathrm{s}}$,

ENGLISH EARTHENWARE. A Handbook to the Wares made in England during the $r_{7}$ th and 18 th Centuries, as illustrated by Wares made in England during the $r 7$ th and $r 8$ th Centuries, as illustrated by
Specimens in the National Collections. With numerous Woodcuts. Large crown $8 \mathrm{vo}, 3 \mathrm{~s}$.

PLAIN WORDS ABOUT WATER. Illustrated. Crown 8 vo, sewed, 6d.

FOOD: Some Account of its Sources, Constituents, and Uses. A New and Revised Edition. Large crown 8vo, cloth, 35.

PRECIOUS STONES: considered in their Scientific and Artistic Relations. With a Coloured Plate and Woodcuts. Second Edition. Large crown $8 \mathrm{vo}$, 25. $6 \mathrm{~d}$. 
COBDEN, RICHARD, LIFE OF. By the Right HoN. JoHN Morley, M.P. With Portrait. New Edition. Crown 8vo, 75. 6d.

Popular Edition, with Portrait, 4to, sewed, IS.; cloth, 23. COLLINS (WILKIE) and DICKENS !(CHARLES)-

THE LAZY TOUR OF TWO IDLE APPRENTICES; NO THOROUGHFARE; THE PERILS OF CERTAIN ENGLISH PRISONERS. With 8 Illustrations, Crown 8vo, 5s.

" These Stories are now reprinted for the first time complete.

\section{COOKERY -}

DINNERS IN MINIATURE. By Mrs. Earl. Crown 8 vo, 25. 6d.

HILDA'S "WHERE IS IT ?" OF RECIPES. Containing many old CAPE, INDIAN, and MALAY DISHES and PRESERVES; also Directions tor Polishung turniture, Cleaning Srlk, etc.; and a Collection of Home Remedies in Case of Sickness, By HuLdagonda J. Duckirt. Interleaved with White Paper for adding Recipes. Third Edition. Crown 8vo, 45. 6d.

THE PYTCHLEY BOOK OF REFINED COOKERY AND BILLS OF FARE, By MAjor L-. Fourth Edition. Large crown 8vo, $8 \mathrm{~s}$.

BREAKFASTS, LUNCHEONS, AND BALL SUPPERS. By MAjor L-. Crown 8 vo. 4 s.

OFFICIAL HANDBOOK OF THE NATIONAL TRAINING SCHOOL FOR COOKERY. Containing Lessons on Cookery. forming the Course of Instruction in the School. Compiled hy "R. O. C." Twenty-first Thousand. Large crown 3vo, 6s.

BREAKFAST AND SAVOURY DISHES. By "R. O. C." Ninth Thousand. Crowr 8vo is.

HOW TO COOK FISH. Compiled by "R. O. C." Crown 8vo, sewed, $3 \mathrm{~d}$.

SICK-ROOM COOKERY. Compiled by "R, O. C." Crown 8vo, sewed, 6d.

THE ROYAL CONFECTIONER : English and Foreign. A Practical Treatise. By C. E. Francatell. Witn aumerous Illustrations. Sixth Thousand. Crowr Jvo, 5 s.

THE KINGSWOOD COOKERY BOOK. By H. F. WICKEN. Crown 3vo, 25.

COOPER-KING (LT.-COL.)-

GEORGE WASHINGTON. Large crown 8vo. With Portrait and Maps.

[In the Prese.

COUPERUS (LOUIS)-

ELINE VERE. Translated from the Dutch by J. T. Grets. Crown 8vo, 5s.

COURTNEY (W. L.), M.A., LL.D., of New College, Oxford-

STUDIES AT LEISURE. Crown 8vo.

[In the Press.

STUDIES NEW AND OLD. Crown 8vo, 6s.

CONSTRUCTIVE ETHICS: A Review of Modern Philo. sophy and its Three Stages of Interpretation, Criticism, and Reconstruction. Demy 8 vo, 125 . 
CRAIK (GEORGE LILLIE)-

ENGLISH OF SHAKESPEARE. Illustrated in a Philological Commentary on "Julius Casar," Eighth Edition. Post 8vo, cloth, 5s.

OUTLINES OF THE HISTORY OF THE ENGLISH LANGUAGE. Eleventh Edition. Post 8vo, cloth, 2s, 6d.

CRA WFURD (OSWALD)-

ROUND THE CALENDAR IN PORTUGAL. With numerous Iilustrations. Royal $8 \mathrm{vo}$, x8s.

BEYOND THE SEAS; being the surprising Adventures and ingenious Opinions of Ralph, Lord St. Keyne, told by his kinsman, Humphrey St, Keyne. Second Edition, Crown 8vo, 3s, 6d.

CRIPPS (WILFRED JOSEPH), M.A., F.S.A.-

COLLEGE AND CORPORATION PLATE. A Handbook for the Reproduction of Silver Plate. With numerons Illustrations, Large crown 8 vo, cloth, 25. $6 \mathrm{~d}$.

CURZON (LOUIS HENRY)-

A MIRROR OF THE TURF; or, The Machinery of Horse-racing Revealed, showing the Sport of Kings as it is to-day. Crown 8 vo.

DAIRY FARMING-

DAIRY FARMING. To which is added a Description of the Chief Continental Systems. With numerous Illustrations. By Jaurs LoNG. Crown 8vo, os.

DAIRY FARMING, MANAGEMENT OF COWS, etc. BY Arthur Roland, Edited by Whliam AnLetr. Crown 8vo, 5s.

$D A L Y(J . B),. L L . D .-$

IRELAND IN THE DAYS OF DEAN SWIFT. Crown $8 \mathrm{vo}, 5$.

DAS (DEVENDRA N.)-

SKETCHES OF HINDOO LIFE. Crown 8vo, 5s.

$D A U B O U R G(E)-$.

INTERIOR ARCHITECTURE. Doors, Vestibules, Staircases, Anterooms, Drawing, Dining, and Bed Rooms, Libraries, Bank and Newspaper Offices, Shop Fronts and Interiors, Half-imperial, cloth, $\ell_{2}$ xas. $6 \mathrm{~d}$.

DAVIDSON (ELLIS A.)-

PRETTY ARTS FOR THE EMPLOYMENT OF L.EISURE HOURS. A Book for Ladies. With Illustrations. Demy 8wo, 6 s.

$D A Y(W I L L I A M)$

THE RACEHORSE IN TRAINING, with Hints on Racing and Racing Reform, to which is added a Chapter on Shoeing. Sixth Edition. Demy 8vo, gs.

DE BOVET (MADAME)-

THREE MONTHS' TOUR IN IRELAND. Translated and Condensed by Mrs. Artuvg Waltres. With Illustrations. Crown $8 \mathrm{vo}^{+}, 6 \mathrm{~s}$,

DE CHAMPEAUX (ALFRED)-

TAPESTRY. With numerous Woodcuts. Cloth, 2s. 6d.

DE FALLOUX (THE COUNT)-

MEMOIRS OF A ROYALIST. Edited by C. B. Pitman. 2 vols. With Portraits. Demy 8 vo, 325.

$D B \operatorname{KONINCK}($ L. L.) and DIETZ $(E)-$.

PRACTICAT, MANUAL OF CHEMICAL ASSAYING, as applied to tne Manufacture of Iron. Edited, with notes, by RoBrrt MALLer. Post 8vo, cloth, 65 . 
DE LESSEPS (FERDINAND)-

RECOLLECTIONS OF FORTY YEARS. Translated from the French by C. B. Prtman. 2 vols. Demy 8vo, 245.

DE LISLE (MEMOIR OF LIEUTENANT RUDOLPH), R.N., of the Naval Brigade, By the Rev. H. N. Oxenhas, M,A. Thind Edition. Crown 8vo, 75. 6d.

$D E$ MANDAT-GRANCEY (BARON E.)-

PADDY AT HOME; OR, IRELAND AND THE IRISH AT the Present Time, as seen ay a Frenchanan. Fifth Edition. Crown 8vo, ts.; in cloth, Is. 6d.

D'OYLE $(L Y N N C Y R I L)$

NOTCHES ON THE ROUGH EDGE OF LIFE, Crown 8 vo, 15. ; in cloth, 1s. 6d.

$D E S T A \ddot{E L}(M A D A M E)-$

MADAME DE STAËL: Her Friends, and Her Influence in Politics and Literature. By LAvY BLennerunssetr. Translated from the German hy J. E. Gordon Cumming. With a Portrait. 3 vols. Demy 8 vo, 365.

DE WINDT $(H)-$.

SIBERIA AS IT IS. With an Introduction by MADAME OLGA NovikofF ("O. K.") Wih numerous Illustrations. Demy 8vo, r8s.

FRUM PEKIN TO CALAIS BY LAND. With numerous Illustrations hy C. E. Fripp from Sketches hy the Author. Derny 8vo, 2os.

A RIDE TO INDIA ACROSS PERSIA AND BELUCHISTAN, With numerous Illustrations and Map. Demy $8 \mathrm{vo}, 16 \mathrm{~s}$,

DICKENS (CHARLES), WORKS BY-See pages $3^{\mathrm{I}}-37$.

THE LETTERS OF CHARLES DICKENS. Two vols, uniform with "The Charles Dickens Edition" of his Works. Crown 8vo, 75.

THE LIFE OF CHARLES DICKENS-See "Forster."

THE CHARLES DICKENS BIRTHDAY BOOK. With Five Illustrations. In a handsome fcap. 4 to volume, r2s.

THE HUMOUR AND PATHOS OF CHARLES DICKkNS, By Charies Kest, With Portrait. Crown Bvo, 6s.

THE DICKENS DICTIONARY. A Key to the Characters and Principal Incidents in the Tales of Charles Dickens. By Giluert PrerCE, with Additions hy WILLIAM A. WHEELER. New Edition, uniform with the "Crown" Edition of Dickens's Works. Large crown 8vo, 35 .

DICKENS (CHARLES) and COLLINS (WILKIE)-

THE LAZY TOUR OF TWO IDLE APPRENTICES; NO THOROUGHFARE; THE PERILS OF CERTAIN ENGLISH PRISONERS. With Illustrations. Crown 8vo, 55.

* * These Stories are now reprinted in complete form for the first time.

$D I L K E(L A D Y)-$

ART IN THE MODERN STATE. With Facsimile. Demy 8vo, gs.

DINARTE (SYLVIO)-

INNOCENCIA : A Story of the Prairie Regions of Brazil. Tranlated from the Portuguese and Illustrated by JAMzS W. WrLLS, F.R.G.S. Crown 8 vo, 65.

$D I X O N(C H A R L E S)-$

THE BIRDS OF OUR RAMBLES: A Companion for the Conntry. With Illustrations hy A. T. Elwes. Large Crown 8vo, 7s 6d.

IDLE HOURS WITH NATURE. With Frontispiece. Crown 8vo, 6s.

ANNALS OF BIRD LIFE: A Year-Book of British Ornithology. With Illustrations. Crown 8vo, 78, 6d, 
DOUGLAS (JOHN)-

SKETCH OF THE FIRST PRINCIPLES OF PHYSIOGRAPHY. With Maps and numerous Illustrations, Crown 8vo, 6s.

DRAYSON (MAIOR-GENERAL A. W.)-

THIRTY THOUSAND YEARS OF THE EARTH'S PAST HISTORY. Large Crown 8vo, 5 s.

EXPERIENCES OF A WOOLWICH PROFESSOR during Fifteen Years at the Royal Military Academy. Demy 8vo, 8s.

PRACTICAL MILITARY SURVEYING AND SKETCHING, Fifth Edition. Post 8vo, cloth, $4 \mathrm{~s}, 6 \mathrm{~d}$.

DUCKITT (HILDAGONDA J.)-

HILDA'S "WHERE IS IT?" OF RECIPES. Containir m many old CAPE, INDIAN, and MALAY DISHES and PRESERVES; also Directions for Polishing Furniture, Cleaning Silk, etc. Third Edition. Crown 8 vo, 4s, $6 \mathrm{~d}$.

DUCOUDRAY (GUSTAVE)-

THE HISTORY OF ANCIENT CIVILISATION. A Handbook based upon M. Gustave Ducondray's "Histoire Sommaire de la Civilisation." Edited by Rev. J. Verschoyt., M.A. With Illustrations. Large crown 8vo, 6s,

THE HISTORY OF MODERN CIVILISATION. With Illustrations, Large crown 8vo, 9 s.

DUFFY (SIR CHARLES GAVAN), R.C.M.G.-

THE LEAGUE OF NORTH AND SOUTH. An Episode in Irish History, $1850-1354$ Crown $8 \mathrm{vo}$, 8s.

DYCE (WILLIAM), R.A.-

DRAWING-BOOK OF THE GOVERNMENT SCHOOL OF DESIGN. Fifty selected Plates. Folio, sewed, 5s.; mounted, 185.

ELEMENTARY OUTLINES OF ORNAMENT. Plates I. to XXII., containing 97 Examples, adapted for Practice of Standards 1, to IV. Sinall folio, sewed, $256 \mathrm{~d}$.

SELECTION FROM DYCE'S DRAWING BOOK. ${ }_{15}$ Plates, sewed, ts. 6d,; mounted on cardboard, 6s. 6d.

TEXT TO ABOVE. Crown 8vo, sewed, 6d.

DYNAMIC ACTION AND PONDEROSITY OF MATTER (FRESH LIGHT ON THE). By Waterdalz. Crown 8vo, 2א, 6d.

EARL (MRS.)-

DINNERS IN MINIATURE. Crown 8vo, 2s. $6 \mathrm{~d}$.

EDWARDS (MRS. SUTHERLAND)-

THE SECRET OF THE PRINCESS. A Tale of Country, Camp, Court, Convict, and Cloister Life in Russia. Crown 8vo, 3s, 6d.

ELLIS (A. B., Major rst West India Regiment)-

THE EWE-SPEAKING PEOPLE OF THE SLAVE COAST OF WEST AFRICA. With Map. Demy 8vo, ros. 6 d.

THE TSHI-SPEAKING PEOPLES OF THE GOLD COAST OF WEST AFRICA: their Religion, Manners, Customs, Laws, Language, \&c. With Map. Demy Bvo, tos. 6d.

SOUTH AFRICAN SKETCHES. Crown 8vo, 6s.

THE HISTORY OF THE WEST INDIA REGIMENT. With Maps and Coloured Frontispiece and Title-page. Demy Bvo, x8s.

THE LAND OF FETISH. Demy 8vo, I2S. 
ENGEL $(C A R L)-$

MUSICAL INSTRUMENTS. With numerous Woodcuts. Large crown 8vo, cloth, 2s. 6d.

$\operatorname{BSCOTT}(T, H . S$.

POLITICS AND LETTERS. Demy 8vo, 9s.

ENGLAND: ITS PEOPLE, POLITY, AND PURSUITS. New and Revised Edition. Demy 8vo, 35. 6d.

EUROPEAN POLITICS, THE PRESENT POSITION OF. By the Author of "Greater Britain." Demy 8vo, ias.

FANE (VIOLET)-

AUTUMN SONGS. Crown 8vo, 6s.

THE STORY OF HELEN DAVENANT. Crown 8vo, 3s. $6 \mathrm{~d}$.

QUEEN OF THE FAIRIES (A Village Story), and other Poems, Crown 8vo, 6s.

ANTHONY BABINGTON : a Drama. Crown 8vo, $6 \mathrm{~s}$.

FARR (WILLIAM) and THRUPP (GEORGE A.)-

COACH TRIMMING. With 60 Illustrations. Crown 8vo, as. $6 \mathrm{~d}$.

FIELD (HENRY $M$.) -

GIBRALTAR. With numerous Illustrations. Demy 8vo, 7s. 6d.

FITZGERALD (PERCY), F.S.A.-

THE HISTORY OF PICKWICK. An Account of its Characters, Localities, Allusions, and Illustrations. With a Bibliography. Derny 8 vo, 8s.

A few copies are issued with impressions from the First Set of Steel Plates, 14s.

FLEMING (GEORGE), F.R.C.S.-

ANIMAL PLAGUES: THEIR HISTORY, NATURE, AND PREVENTION. 8vo, cloth, 15s.

PRACTICAL HORSE-SHOEING. With 37 Illustrations. Fifth Edition, enlarged. 8vo, sewed, 28.

RABIES AND HYDROPHOBIA: THEIR HISTORY, NATURE, CAUSES, SYMPTOMS, AND PREVENTION. With 8 Illustrations. 8vo, cloth, 155 .

FORSTER (FOHN)-

THE LIFE OF CHARLES DICKENS. Original Edition. Vol. I., 8vo, cloth, 128. Vol. II., 8vo, cloth, I4s. Vol. III., 8vo, cloth, 165 ,

Uniform with the Illustrated Library Edition of Dickens's Works. 2 vols. Demy 8 vo, sos.

Uniform with the Library and Popular Library Editions. Post 8vo, xos. 6d. each.

Uniform with the "C. D." Edition. With Numerous Illustrations, 2 vols. $7 \mathrm{~s}$.

Uniform with the Crown Edition. Crown 8vo. [In the Press.

Uniform with the Household Edition. With Illustrations by F. BARnard, Crown 4 to, cloth, 5 s.

FORSTER, THE LIFE OF THE RIGHT HON. W. E. By T. WEsyss Reid, With Portraits, Fourth Edition. a vols. Demy 8vo, $32 s$. FIFTH EDITION in one volume with new Portrait. Demy 8 vo, xos. $6 \mathrm{~d}$. 
FORSYTH $(C A P T A I N)-$

THE HIGHLANDS OF CENTRAL INDIA: Notes on their Forests and Wild Tribes, Natural History and Sports. With Map and Coloured lllustrations, A New Edition. Demy 8vo, ras.

FORTNIGHTLY REVIEW (see page 40)-

FORTNIGHTLY REVIEW.-First Series, May, $\mathbf{1 8 6}$, to Dec. $\times 866.6$ vols. Cloth, r3s. each.

New Series, 1867 to 1872 . In Half-yearly Volumes. Cloth, I3s. each.

From January, 1873 , to the present time, in Half-yearly Volumes. Cloth, 16 s. each.

CONTENTS OF FORTNIGHTLY REVIEW. From the commencement to end of $x 878$. Sewed, as.

FORTNUM (C. D. E.), F.S.A.-

MAIOLICA. With numerous Woodcuts. Large crown 8vo, cloth, 2s, 6d.

BRONZES. With numerous Woodcuts. Large crown 8 vo, cloth, 2s, 6d.

FOUQUÉ (DE LA MOTTE)-

UNDINE : a Romance translated from the German. With an 1 ntroduction by Julia Caktwright. Illustrated by Heywood Sumise. Crown 4 to, 5 s.

FRANCATELLI (C. E.)-

THE ROYAL CONFECTIONER: English and Foreign. A Practical Treatise. With lllustrations. Sixth Thousand. Crown $8 \mathrm{vo}, 5 \%$

FRANKS (A. W.) -

JAPANESE POTTERY. Being a Native Report, with an Introduction and Catalogue. With numerous Illustrations and Marks. Large crown 8vo, cloth, 2s. $6 \mathrm{~d}$.

FROBEL, FRIEDRICH ; a Short Sketch of his Life, including Frobbel's Letters from Dresden and Leipzig to his Wife, now first Translated into English. By Emilv Shirrefr. Crown 8vo, 2s.

GALLENGA (ANTONIO)-

ITALY: PRESENT AND FUTURE. 2 vols. Dmy.8vo, 2 Is. EPISODES OF MY SECOND LIFE. 2 vols. Dmy. 8vo, $28 \mathrm{~s}$. IBERIAN REMINISCENCES. Fifteen Years' Travelling Impressions of Spain and Portugal. With a Map. 2 vols. Demy 8vo, 325.

GASNAULT (PAUL) and GARNIER (ED.)-

FRENCH POTTERY. With Illustrations and Marks. Large crown 8vo, $3^{\text {s. }}$

GILLMORE (PARKER)-

THE HUNTER'S ARCADIA. With numerous Illustrations. Demy 8vo, ros. 6d.

GIRL'S LIFE EIGHTY YEARS AGO (A). Selections from the Letters of Eliza Southgate Bowne, with an Introduction by Clarence Cook. Illustrated with Portraits and Views. Crown 4 to, 125. 
GLEICHEN (COUNT), Grenadier Guards-

WITH THE CAMEL CORPS UP THE NILE. With numerous Sketches by the Author. Third Edition, Large crown $8 v 0,9 s$.

GORDON (GENERAL)-

LETTERS FROM THE CRIMEA, THE DANUBE, AND ARMEN1A. Edited by Desetrivs C. Bovlger. Second Edition: Crown 8vo, 5s.

GORST (SIR F. E.), Q.C., M.P.-

An ELECTION MANUAL. Containing the Parliamentary Elections (Corrupt anc' Illegal Practices) Act, $188_{3}$, with Notes. Third Edition. Crown 8vo, $1 \mathrm{~s}$. 6d.

GOWER (A. R.), Royal School of Mines-

PRACTICAL METALLURGY. With Illustrations. Crown $8 \mathrm{vo}, 3^{3 .}$

GRESWELL (WILLIAM), M.A., F.R.C.I.-

OUR SOUTH AFRICAN EMPIRE. With Map. 2 vols. Crown 8vo, 2xs.

GRIFFIN (SIR LEPEL HENRY), K.C.S.I.-

THE GREAT REPUBLIC. Second Edition. Crown 8vo, $4^{\mathrm{s},} 6 \mathrm{~d}$.

GRIFFITHS (MAFOR ARTHUR), H.M. Inspector of Prisons-

FRENCH REVOLUTIONARY GENERALS. Large crown 8vo, 6s.

CHRONICLES OF NEWGATE, Illustrated. New Edition. Demy 8vo, 165.

MEMORIALS OF MILLBANK: or Chapters in Prison History. With Illustrations. New Edition. Demy vo, I2s.

HALL (SIDNE Y)-

A TRAVELLING ATLAS OF THE ENGLISH COUNTIES. Fifty Maps, coloured. New Edition, including the Railways, corrected up to the present date. Demy jvo, ir roan tuck, ios. 6 d.

HAWKINS (FREDERICK)-

THE FRENCH STAGE IN THE EIGHTEENTH CENTURY. With Portraits, 2 vols. Demy 8 vo, 305 .

ANNALS OF THE FRENCH STAGE: FROM ITS ORIGIN TO THE DEATH OF RACINE. \& Portraits. a vols. Demy 8vo, z8s.

HILDEBRAND (HANS), Royal Antiquary of Sweden-

INDUSTRIAL ARTS OF SCANDINAVIA IN THE PAGAN T1ME, With numerous Woodcuts. Large crown 8vo, 2s, 6 d.

HILL (MISS G.)-

THE PLEASURES AND PROFITS OF OUR LITTLE POULTRY FARM. Small 8 vo, 3 s,

HOLBEIN-

TWELVE HEADS AFTER HOLBEIN. Selected from Drawings in Her Majesty's Collection at Windsor. Reproduced in Autotype, in portfolio. \&I $16 \mathrm{~s}$. 
HOLMES (GEORGE C. V.), Secretary of the Institution of Naval ArchitectsMARINE ENGINES AND BOILERS. With Sixty-nine Woodcuts. Large crown 8vo, 3 s.

HOPE (ANDRÉE)-

CHRONICLES OF AN OLD INN; or, a Few Words about Gray's lnn. Crown 8vo, 5 s.

HOUSSAYE (ARSENE)-

BEHIND THE SCENES OF THE COMÉDIE FRANCAISE, AND OTHER RECOLLECTIONS. Translated from the French. Demy 8 vo, 145 .

HOVELACQUE $(A B E L)-$

THE SCIENCE OF LANGUAGE: LINGUISTICS, PH1LOLOGY, AND ETYMOLOGY. With Maps. Large crown 8vo, cloth, 5s,

HOZIER (H, M.)-

TURENNE. With Portrait and Two Maps. Large crown $8 \mathrm{vo}, 4 \mathrm{~s}$.

HUDSON (W. H.), C.M.Z.S. Joint Author of "Argentine Ornithology"-

THE NATURALIST IN LA I'LATA. With numerous lllustrations. Demy $8 \mathrm{vo}$, I 6 s.

HUEFFER $($ F.) -

HALF A CENTURY OF MUSIC IN ENGLAND. 1837-1887. Demy 8vo, 8s.

HUGHES (W.R.), F.L.S.-

A WEEK'S TRAMP IN DICKENS-LAND. With npwards of roo lilustrations hy F. G. Kitrox, Henserr RAlLton, and others. Iemy 8 vo, 165 .

HUNTLY (MARQUIS OF)-

TRAVELS, SPORTS, AND POLITICS IN THE EAST OF EUROPE. With lllustrations by the Marchioness of Huntly. Lange Crown 8vo, I2s.

INDUSTRIAL ARTS: Historical Sketches. With numerous Illustrations. Large crown 8vo, 3 s.

I ACKSON (FRANK G.), Master in the Birmingham Munucipal School of Art-

DECORATIVE DESIGN. An Elementary Text Book of Principles and Practice. With numercus llinstrations. Second Edition. Crown $8 \mathrm{vo}, 75.6 \mathrm{~d}$.

FAMES (HENRY A.), M.A.-

HANDBOOK TO PERSPECTIVE. Crown 8vo, 2s. 6d.

PERSPECTIVE CHARTS, for use in Class Teaching. 2s.

FARRY $($ GENERAL)-

OUTPOST DUTY. With TREATISES ON MILITARY RECONNAISSANCE AND ON ROAD-MAK1NG. By Major-Gen. W. C. E. NAPIER, Third Edition. Crown 8vo, 5s.

FEANS $(W, T$.) -

CREATORS OF THE AGE OF STEEL. Memoirs of Sir W. Siemens, Sir H. Bessemer, Sir J. Whitworth, Sir J. Brown, and other Inventors, Second Edition. Cruwn 8vo, 7s, $6 \mathrm{~d}$.

JOKAI (MAURICE)-

PRETTY MICHAL. Translated by R. NisBet BAIN. Cro an 8vo, 5 .

YONES (CAPTAIN DOUGLAS), R.A.-

NOTES ON MILITAKY LAW. Crown 8vo, 45 . 
JONES. HANDBOOK OF THE JONES COLLECTION IN THE SOUTH KENSINGTON MUSEUM. With Portrait and Woodcuts. Large crown 8 vo, 25. 6d.

FOPLING (LOUISE) -

HINTS TO AMATEURS. A Handbook on Art. With Diagrams. Crown 8vo, Is, 6d.

GUNKER (DN. WM.)-

TRAVELS IN AFRICA. Translated from the German by Professor KEANE.

by Professor KEANE.
Vol. I. DURING the YEARS 1875 to 1878 . Containing $3^{8}$ Full-page Plates and 125 Illustrations in the Text and Map. Demy 8vo, 2xs.

vol. II. DURING the YEARS 1879 to 1883 . Containing numerous Eull-page

Plates, and llustrations in the Text and Mlap. Demy dvo, 215.
[ $/ n$ the Press.

KENNARD (EDWARD)-

NORWEGIAN SKETCHES : FISHING IN STRANGE WATERS. Illustrated with 30 beantiful Sketches, Second Edition. Oblong folio, 21s.

Smaller Edition. $14 \mathrm{~s}$.

KING (LIEUT,-COL. COOPER)-

GEORGE WASHINGTON. Large crown 8vo. IIn the Press. KLACZKO (M. ₹ULIAN)-

TWO CHANCELLORS : PRINCE GORTCHAKOF AND PRINCE BISMARCK. Translated byMrs, TaIt, Newand cheaper Edition, $6 \mathrm{s.}$

LACORDAIRE (PËRE)-

JESUS CHRIST; GOD; AND GOD AND MAN. Conferences delivered at Notre Dame in Paris. New Edition. Crown 8vo, 6s.

LAINE (F. M.), R.A.-

ENGLISH COMPOSITION EXERCISES. Crown 8vo, 2s. $6 \mathrm{~d}$.

LAING $\stackrel{2 \mathrm{~S}}{(\mathrm{~S} .)-}$ -

PROBLEMS OF THE FUTURE AND ESSAYS. Eighth Thousand. Demy 8vo, 35. 6d.

MODERN SCIENCE AND MODERN THOUGHT. Twelith Thousand. Demy 8vo, 3s, 6d.

A MODERN ZOROASTRIAN. Fifth Thousand. Demy $8 v 0,3 s .6 \mathrm{~d}$.

LAMENNAIS (F.)-

WORDS OF A BELIEVER, and THE PAST AND FUTURE OF THE PEOPLE. Translated from the French by $L$, $L$. Martinenu. With a Memoir of Lamennais. Crown $8 \mathrm{vo}, 4 \mathrm{~s}$.

$\angle A N D O R(W . S)-$.

LIFE AND WORKS. 8. vols.

Vols 1. Out of print.

VoL. 2. Out of print

VoL. 3. CONYERSATIONS OW SOVEREIGNS AND STATESMEN, AND

Demy 8vo
Vol. 4. DIALCUUES O LTTERARY MNN. Drmy fro, Iss. FAMOUS

VOL. 5. DIAIOGUES OE LEIETAYY MEN (coninat). FAMOUS
WOMEN. LETTERS OF FERICLES AND ASPASIA. And Minor Prose Pieces. Dem: \&vo. 14 .

Vol. 6. MISCELLANEOUS CONVEESAIIONS. Demv 8vo, 14s. Poems.
Vol. 7. GEDIR, ACIS AND SCENES AND HELLENICS. Pors Dem7 Bvo. iAs.

VoL. 8. MISCELIANEOUS POEMS AND CRITICISMS ON THEO. CRITUS, CATULLUS, AND PETRARCH. Demy 8vo, 145. 


\section{LANIN (E. B.) -}

RUSSIAN CHARACTERISTICS. Reprinted, with Revisions, from The Forlrightly Review. Demy 8vo.

LAVELEYE ( $\bar{E} M I L E D E)-$

THE ELEMENTS OF POLITICAL ECONOMY. Translated by W. Pollard, B.A., St. John's College, Oxford. Crown 8vo, 6s.

$L E$ CONTE (JOSEPH), Professor of Geology and Natural History in the Uni. versity of California-

EVOLUTION: ITS NATURE, ITS EVIDENCES, AND ITS RELATIONS TO RELIGIOUS THOUGHT. A New and Revised Edition. Crown 8vo, 6s.

LEFEVRE (ANDRÉ)-

PHILOSOPHY, Historical and Critical. Translated, with an Introduction, by A. W. KEANE, B.A. Large crown 8vo, 3s. 6d.

LE ROUX (H.) -

ACROBATS AND MOUNTEBANKS. With over 200 Illustrations by $\mathrm{J}$. GARNIER, Royal 8 vo, xes.

LESLIE $(R, C)-$.

OLD SEA WINGS, WAYS, AND WORDS, IN THE DAYS OF OAK AND HEMP. Witb $x_{35}$ Illustrations by the Author. Demy 8vo, I4s.

LIFE ABOARD A BRITISH PRIVATEER IN THE TIME OF QUEEN ANNE. Being the Jonrnals of Captain Woodes Rogers, Master Mariner, With Notes and Illustrations by RoBekt C. LESLIE, Large crown 8vo, os.

A SEA PAINTER'S LOG. With I 2 Full-page Illustrations by the Autbor. Large crown $8 \mathrm{vo}, 12 \mathrm{~s}$.

LRTOURNEAU (DR, CHARLES)-

SOCIOLOGY. Based upon Ethnology. Large crown 8vo, 3s. 6d.

BIOLOGY. With 83 Illustrations. A New Edition. Demy 8 vo, 3s. 6d.

LILLY (W.S.)-

ON SHIBBOLETHS. Demy 8vo, I 2 s.

ON RIGHT AND WRONG. Second Editıon. Demy 8vo, 125.

A CENTURY OF REVOLUTION. Second Edition. Demy 8vo, ras.

CHAPTERS ON EUROPEAN HISTORY. With an Introductory Dialogue on the Philosophy of History. 2 vols. Demy 8vo, 2Is.

ANCIENT RELIGION AND MODERN THOUGHT. Second Edition. Demy 8vo, $x 25$.

LITTLE (THE REV. CANON KNOX)-

THE CHILD OF STAFFERTON : A Chapter from a Family Chronicle. New Edition. Crown 8vo, boards, Is.; clotb, Is. $6 \mathrm{~d}$.

THE BROKEN VOW. A Story of Here and Hereafter. New Edition. Crown 8vo, boards, xs.; cloth, Is. 6d.

LITTLE (THE REV. H. W.)-

H. M. STANLEY : HIS LIFE, WORKS, AND EXPLORATIONS. Demy 8vo, 10s. 6d 
LLOYD (COLONEL E.M.), R.E.-

VAUBAN, MONTALEMBERT, CARNOT: ENGINEER STUDIES. With Portraits. Crown 8vo, ss

LLOYD (W. W.), late atth RegimentON ACTIVE SERVICE. Printed in Colours. Oblong

SKETCHES OF INDIAN LIFE. Printed in Colours. 4 to, 6s.

LONG (JAMES)-

DAIRY FARMING. To which is added a Description of the Chief Continental Systems. With numerous Illustrations. Crown $8 v 0,95$.

LOVELL (ARTHUR)-

THE IDEAL OF MAN. Crown 8vo, 3s. 6d.

LOW (WILLIAM)-

TABLE DECORATION. With I9 Full Illustrations. Demy $8 \mathrm{vo}^{2} 6 \mathrm{~s}$.

$\operatorname{McCOAN}$ (J. C.)

EGYPT UNDER ISMAIL: a Romance of History. With Portrait and Appendix of Official Documents. Crown 8vo, 7s. 6d.

MALLESON (COL. G. B.), C.S.I.-

PRINCE EUGENE OF SAVOY. With Portrait and Maps. Large crown $8 v 0,6 s$.

LOUDON. A Sketch of the Military Life of Gideon Ernest, Freicherr von Loudon. With Portrait and Maps, Large crown 8vo, $4 \mathrm{~s}$.

MALLET (ROBERT)-

PRACTICAL MANUAL OF CHEMICAL ASSAYING, as applied to the Manufacture of Iron. By L. L. DE Koninck and E. Dietz. Edited, with notes, by RonsRT MALLET. Post 8vo, cloth, 6s.

MARCEAU (SERGENT)-

REMINISCENCES OF A REGICIDE. Edited from the Original MSS. of Sergeent Marcenu, Member of the Convention, and Administrator of Police in the French Reyolution of ${ }_{17} \mathrm{~g} g$. By M. C. M. Simpson. Demy 8vo, witi Illustrations and Portraits, 145.

MASKELL (ALFRED)-

RUSSIAN ART AND ART OBJECTS IN RUSSIA. A Handbcok to the Reproduction of Goldsmiths' Work and other Art Treasures With Illustrations. Large crown $5 v 0,45.6 \mathrm{~d}$.

MASKRLL (WILLIAM)-

IVORIES: ANCIENT AND MEDIAEVAL, With numerous Woodcuts. Large crown $8 v 0$, cloth, 2s. 6d.

HANDBOOK TO THE DYCE AND FORSTER COL LECTIONS. With Illustrations. Large crown 8 vo, cloth, 2s. $6 \mathrm{~d}$.

MASPÉRO (G.), late Director of Archaology in Egypt, and Member of th Institute of France-

LIFE IN ANCIENT EGYPT AND ASSYRIA. Translated by A. P. Morron. With 188 Illustrations, Crown 8vo, 5s,

MAUDSLAY (ATHOL)-

HIGHWAYS AND HORSES. With numerous Illustra. tions, Demy Bvo, 2rs. 


\section{GEORGE MEREDITH'S WORKS.}

$A$ New and Uniform Edition. Crown 8vo, 3s. 6d. each.

Copies of the Sir.Shilling Edition are still to be had.

ONE OF OUR CONQUERORS.

DIANA OF THE CROSSWAYS.

EVAN HARRINGTON.

THE ORDEAL OF RICHARD FEVEREL.

THE ADVENTURES OF HARRY RICHMOND.

SANDRA BELLONI.

VITTORIA.

RHODA FLEMING.

BEAUCHAMP'S CAREER.

THE EGOIST.

THE SHAVING OF SHAGPAT; AND FARINA.

\section{MERIVALE (HERMAN CHARLES)-}

BINKO'S BLUES. A Tale for Children of all Growths.

Illustrated by EDGAR GIBErang. Small crown 8vo, ss.

THE WHITE PILGRIM, and other Poems. Crown 8vo, 9 s. MILLS ( $($ OHN), formerly Assistant to the Solar Physics Committec-

ADVANCED PHYSIOGRAPHY (PHYSIOGRAPHIC ASTRONOMY). Designed to meet the Requitements of Students preparing for the Elementary and Advanced Stages of Physiography in the Science and Art Department Examinations, and as an Introduction to Physical Astronomy. Crown 8vo, 4s. 6d.

ELEMENTARY PHYSIOGRAPHIC ASTRONOMY. Crown 8vo. 1s, 6d,

ALTERNATIVE ELEMENTARY PHYSICS. Crown $8 \mathrm{vo}, 2 \mathrm{~s}, 6 \mathrm{~d}$.

MILLS (FOHN) and NORTH (BARKER)-

QUANTITATIVE ANALYSIS (INTRODUCTORY LESSONS ON). With numerous Woodcuts. Crown 8vo, Is. 6d.

HANDBOOK OF QUANTITATIVE ANALYSIS. Crown $8 \mathrm{vo}, 35.6 \mathrm{~d}$.

MILNERS, THE; OR, The River Diggings. A Story of South African Life. Crown 8vo, 6s.

MOLRSWORTH (W. NASSAU)-

HISTORY OF ENGLAND FROM THE YEAR I830 TO THE RESIGNATION OF THE GLADSTONE MINISTRY, 1874 . Twelfith Thousand. 3 vols. Crown 8vo, 28 s.

ABRIDGED EDITION. Large crown, $7 \mathrm{~s} .6 \mathrm{~d}$. MOLTKE (FIELD-MARSHAL COUNT VON)-

POLAND: AN HISTORICAL SKETCH. With Biographical Notice by E. S. Bucннегм, Crown 8vo, 1s,

MOOREHEAD (WARREN $K$.)-

WANNETA, THE SIOUX. With Illustrations from Life. Large crown 8vo, 6 s. 
MORLEY (THE RIGHT HON. FOHN), M.P.-

RICHARD COBDEN'S LIFE AND CORRESPONDENCE. Crown 8vo, with Portrait, 7s. 6c.

Popular Edition. With Portrait. 4to, sewed, Is. Cloth, 2S. MURRAY (ANDREW), F.L.S.-

ECONOMIC ENTOMOLOGY. APTERA. With numerous Illustrations. Large crowa $8 \mathrm{vo}, 35,6 \mathrm{~d}$.

MURRAY (HENRY)-

A DEPUTY PROVIDENCE. Crown 8vo, 3s. 6d.

NECKER (MADAME)-

THE SALON OF MADAME NECKER. By VICOMTE D'Haussonvite. a vols. Crown bvo iss

NESBITT (ALEXANDER)-

GI.ASS. With numerous Woodcuts. Large crown 8vo, cloth, $25.6 \mathrm{~d}$.

NICOL $(D A V I D)$

THE POLITICAL LIFE OF OUR TIME. Two vols. Demy 8vo, 24s.

NORMAN (C. B.)-

TONKIN; OR, FRANCE IN THE FAR EAST. With Maps. Demy 8 vo, r4s.

O'BYRNE (ROBERT), F.R.G.S.-

THE VICTORIES OF THE BRITISH ARMY IN THE PENINSULA AND THE SOUTH OF FRANCE from $x 808$ to $18 \mathrm{r}$. An Epitome of Napier's History of the Peninsular War, and Gurwood's Collection of the Duke of Wellington's Despatches. Crown 8vo, 5 s.

O'GRADY (STANDISH)-

TORYISM AND THE TORY DEMOCRACY. Crown $8 \mathrm{vo}, 55$.

OLIVER (PROFESSOR D.), F.R.S., \& c,-

ILLUSTRATIONS OF THE PRINCIPAL NATURAL ORDERS OF THE VEGETABLE KINGDOM, PREPARED FOR THE SCIENCE AND ART DEPARTMENT, SOUTH KENSINGTON. With rog Plates. Oblong Bvo, plain, I6s.; coloured, 6I 6s.

OLIVER (E. E.), Under-Secretary to the Public Works Department, Punjaub-

ACROSS THE BORDER; or, PATHAN AND BILOCH. With numerous Illustrations by J. L. KipLING, C.I.E. Demy 8 vo, I4s.

PAPUS-

THE TAROT OF THE BOHEMIANS. The most ancient book in the world. For the exclusive use of the Initiates. An Absolute Kev to Occult Science. Translated by A. P. Mostos. With numerous Illustrations. Large crown 8vo, 75. 6. .

PATERSON (ARTHUR)-

A PARTNER FROM THE WEST. Crown 8vo, 5 s.

PAYTON $($ R., W. ) -

ROUND ABOUT NEW ZEALAND. Being Notes from a Journal of 'Three Years' Wandering in the Antipodes. With Twenty original Illustrations by the Author. Large crown 8vo, I25. 
PERROT (GEORGES) and CHIPIEZ (CHARLES)-

A HISTORY OF ANCIENT ART IN PERSIA. With 254 Iliustrations, and 12 Steel and Coloured Plates, Imperial 8vo, 2rs.

A HISTORY OF ANCIENT ART IN PHRYGIALYDIA, AND CARIA-LYCIA. With 280 Illustrations. Imperial $8 \mathrm{vo}, \mathbf{r}_{5}$ s.

A HISTORY OF ANCIENT ART IN SARDINIA, JUDAA, SYRIA, AND ASIA MINOR, With 395 Illustrations. 2 vols. Imperial 8vo, $36 \mathrm{~s}$.

A HISTORY OF ANCIENT ART IN PHCENICIA AND ITS DEPENDENCIES. With 654 Illustrations. a vols. Imperial $8 \mathrm{vo}, 425$.

A HISTORY OF ART IN CHALD AA AND ASSYRIA. With 452 Illustrations. 2 vols. Imperial $8 \mathrm{vo}, 42 \mathrm{~s}$.

A HISTORY OF ART IN ANCIENT EGYPT. With 600 Illustrations. 2 vols. Imperial $8 \mathrm{vo}, 425$.

PETERBOROUGH (THE EARL OF)-.

THE EARL OF PETERBOROUGH AND MONMOUTH (Charles Mordaunt): A Memoir. By Colonel Frank Russell, Royal Dragoons, With lllustrations. 2 vols. demy 8 vo. $32 s$.

PIERCE (GILBERT)-

THE DICKENS DICTIONARY. A Key to the Characters and Principal Incidents in the Tales of Charles Dickens, with Additions by WilinM A. Wherler. New Edition, uniform with the Crown Edition of Dickens's Works. Large crown 8vo, 5 s.

PILLING (WILLIAM)-

LAND TENURE BY REGISTRATION. Second Edition of "Order from Chaos," Revised and Enlarged. Crown 8vo, 5 s.

PITT TAYLOR (FRANK)-

THE CANTERBURY TALES. Selections from the Tales of Groftrey Chaucre rendered into Modern English, Crown 8vo, 6s.

POLLEN (F. H.)-

GOLD AND SILVER SMITH'S WORK. With numerous Woodcuts, Large crown 8vo, cloth, 2s. 6d.

ANCIENT AND MODERN FURNITURE AND WOODWORK. With numerous Woodcuts. Large crown 8vo, cloth, 25, 6d.

POOLE (STANLEY LANE), B.A., M.R.A.S.-

THE ART OF THE SARACENS IN EGYPT. Published for the Committee of Council on Education. With ro8 Woodcuts. Large crown 8 vo, 4s.

POYNTER ( $E, \mathcal{F}.), R, A$.

TEN LECTURES ON ART. Third Edition. Large crown 8vo, gs,

PRATT (ROBERT), Headmaster School of Scicnce and Art, Barronv-in-Furness-

SCIOGRAPHY, OR PARALLEL AND RADIAL PROJECTION OF SHADOWS. Being a Course of Exercises for the use of Students in Architectural and Engineering Drawing, and for Candidates preparing for the Examinations in this subject and in Third Grade Perspective conducted by
the Science and Art Department. Oblong quarto, 7s. 6d. 
PURCELL (the late THEOBALD A.), Surgeon-Major, A.M.D., and Principal Medical Officer to the Fapanese Government) -

A SUBURB OF YEDO. With numerous Illustrations. Crown 8 vo, 2s. 6 d.

RADICAL PROGRAMME, THE. From the Fortnightly Revicw, with additions. With a Preface hy the Right Hos. J. ChamberLark, M,P. Thirteenth Thousand. Crown 8vo, 25. 6d.

RAE (W. FRASER)-

AUSTRIAN HEALTH RESORTS THROUGHOUT THE YEAR. A New and Enlarged Edition. Crown 8vo, 5 s.

RAMSDEN (LADY GWENDOLEN)-

A BIRTHDAY BOOK. Containing 46 Illustrations from Original Drawings, and numerous other Illustrations. Royal 8vo, 2xs.

RANKIN (THOMAS T.), C.E.-

SOLUTIONS TO THE QUESTIONS IN PURE MATHEMATICS (STAGES I AND 2 ) SET AT THE SCIENCE AND ART EXAMINATIONS FROM I88I TO 1886 . Crown 8vo, $2 \mathrm{~s}$.

RAPHAEL: his Life, Works, and Times. By Eugene Muntz. Illustrated with about 20 Engravings, A New Edition, revised from the Second French Edition. By W. ArMstrong, B.A. Imperial 8vo, 25s.

$R E A D E$ (MRS, R. H.) -

THE GOLDSMITH'S WARD; A Tale of London City in the Fifteenth Century. With 27 Illustrations hy W. Bowcher. Crown Bvo, 65.

REDGRAVE (GILBERT)-

OUTLINES OF HISTORIC ORNAMENT. Translated from the German. Edited hy GiLbert RgDGrave. With numerous Illustrations. Crown $8 \mathrm{vo}, 4 \mathrm{~s}$.

REDGRAVR (RICHARD), R.A.-

MANUAL OF DESIGN. With Woodcuts. Large crown $8 \mathrm{vo}$, cloth, 25. 6d.

ELEMENTARY MANUAL OF COLOUR, with a Catechism on Colour. $24 \mathrm{mo}$, cloth, gd.

REDGRAVE (SAMUEL)-

A DESCRIPTIVE CATALOGUE OF THE HISTORICAL COLLECTION OF WATER-COLOUR PAINTINGS IN THE SOUTH KENSINGTON MUSEUM, With numerous Chromo-lithographs and other Illustrations. Royal 8 yo, \&I Is.

$R E I D(T, W E M Y S S)-$

THE LIFE OF THE RIGHT HON. W. E. FORSTER. With Portraits. Fourth Edition. 2 vols. Demy $8 \mathrm{vo}_{3} 325$.

FIFTH EDITION, in one volume, with new Portrait. Demy $8 \mathrm{vo}_{1}$ ros, $6 \mathrm{~d}$

RENAN (ERNEST)-

THE FUTURE OF SCIENCE: Ideas of 1848 . Demy 8vo, r8s.

HISTORY OF THE PEOPLE OF ISRAEL.

Frrst Division. Till the time of King David. Demy $8 v 0, r_{4}$ s.

SEcond Division. From the Reign of David up to the Capture of Samaria.

Demy $8 \mathrm{vo}^{1} \mathrm{x}_{4}$ s. From the time of Hezekiah till the Return from Babylon.
Turn Drvision. From Demy 8vo, r.45.

RECOLLECTIONS OF MY YOUTH. Translated from the French, and revised by Madame Rensus. Crown 8vo, 8s. 
RIANO (YUAN F.)-

THE INDUSTRIAL ARTS IN SPAIN. With numerous Woodcuts. Large crown 8 vo, cloth, 45.

RIBTON-TURNER (C. J.)-

A HISTORY OF VAGRANTS AND VAGRANCY AND BEGGARS AND BEGGING. With Illustrations. Demy 8vo, zis.

ROBINSON ( 7 AMES F.)-

BRITISH BEE FARMING. Its Profits and Pleasures. Large crown 8vo, $5 \mathrm{~s}$.

ROBINSON (7. C.)-

ITALIAN SCULPTURE OF THE MIDDLE AGES AND PERIOD OF THE REVIVAL OF ART. With 20 Engrayings. Royal $8 \mathrm{vo}$, cloth, 7s. 6d.

ROBSON (GEORGE)-

ELEMENTARY BUILDING CONSTRUCTION. Illustrated by a Design for an Entrance Lodge and Gate. I5 Plates. Oblong folio, sewed, $8 \mathrm{~s}$.

ROCK (THE VERY REV. CANON), D.D.-

TEXTILE FABRICS. With numerous Woodcuts. Large crown 8vo, cloth, 28. $6 \mathrm{~d}$.

ROGERS (CAPTAIN WOODES), Master Marinem-

LIFE ABOARD A BRITISH PRIVATEER IN THE TIME OF QUEEN ANNE. With Notes and Illustrations by ROBERT C. L Lst.TE, Large crown $8 \mathrm{vo}$, gs.

ROOSE (ROBSON), M.D., F.C.S.-

THE WEAR AND TEAR OF LONDON LIFE. Second Edition. Crown 8vo, sewed, xs.

INFECTION AND DISINFECTION. Crown8vo,sewed,6d. ROOSEVELT (BLANCHE)-

ELISABETH OF ROUMANIA: A Study. With Two Tales from the German of Carmen Sylva, Her Majesty Queen of Roumania. With Two Portraits and Illustration. Deny 8vo, 12s.

ROLAND (ARTHUR)-

FARMING FOR PLEASURE AND PROFIT. Edited by WrLlam AвLets. 8 vols. Crown 8 vo, 5 s, each,

DAIRY-FARMING, MANAGEMENT OF COWS, etc. POULTRY-KEEPING.

TREE-PLANTING, FOR ORNAMENTATION OR PROFIT.

STOCK-KEEPING AND CATTLE-REARING.

DRAINAGE OF LAND, IRRIGATION, MANURES, etc.

ROOT-GROWING, HOPS, etc.

MANAGEMENT OF GRASS LANDS, LAYING DOWN GRASS, ARTIFICIAL GRASSES, etc.

MARKET GARDENING, HUSBANDRY FOR FARMERS AND GENERAL CULTIVATORS

ROSS (MRS. FANET)-

EARLY DAYS RECALLED. With Illustrations and Portrait. Crown $8 v 0,5 s$.

$\operatorname{ROSS}($ RONALD)--

THE DEFORMED TRANSFORMED: A Drama in Five

Acts. Crown 8vo, 3s, 6d. 
SCHREINER (OLIVE), (RALPH IRON)-

THE STORY OF AN AFRICAN FARM. Crown 8vo, xs. ; in cloth, $15 ; 6 \mathrm{~d}$.

A Limrary Edition, on Superior Paper, and Strongly Bound in Cloth. Crown 8vo, 3s, 6 d. SCHAUERMANN (F. L.)-

WOOD-CARVING IN PRACTICE AND THEORY, AS APPLIED TO HOME ARTS. With Notes on Designs having special application to Carved Wood in different styles. Containing 124 Illustrations. Large crown 8vo, 7 s. $6 \mathrm{~d}$.

SCIENCE AND ART: a Journal for Teachers and Scholars. Issued monthly. $3 \mathrm{~d}$. See page 38.

$\operatorname{SCOTT}(\mathrm{JOHN})-$

THE REPUBLIC AS A FORM OF GOVERNMENT; or, The Evolution of Democracy in America. Crown 8vo, 75, $6 \mathrm{~d}$.

$\operatorname{SCOTT}(L E A D E R)-$

THE RENAISSANCE OF ART IN ITALY : an Illustrated Sketch. With upwards of 200 Illustrations. Medium quarto, 185 .

SCOTT-STEVENSON (MRS.)-

ON SUMMER SEAS. Including the Mediterranean, the Egean, the Ionian, and the Euxine, and a voyage down the Danube. With a Map. Demy 8vo, 16 s.

OUR HOME IN CYPRUS. With a Map and Illustrations. Third Edition. Demy 8vo, 14s.

OUR RIDE THROUGH ASIA MINOR. With Map. Demy 8vo, x8s.

SEEMAN (O.)-

THE MYTHOLOGY OF GREECE AND ROME, with Special Reference to its Use in Art. From the German. Edited hy G. H. BLANCHI. 64 Illustrations. New Edition. Crown 8vo, 55.

SETON.KARR (H. W.), F.R.G.S., etc.-

BEAR HUNTING IN THE WHITE MOUNTAINS; or, Alaska and British Columbia Rovisited. Illustrated. Large Crown, $4^{45} 6 \mathrm{~d}$.

TEN YEARS' TRAVEL AND SPORT IN FOREIGN Lands; or, Travels in the Eighties. Second Edition, with additions and Portrait of Author. Large crown 8vo, 58 .

SHEPHERD (MATOR), R.E.-

PRAIRIE EXPERIENCES IN HANDLING CATTLE AND SHEEP. With Illustrations and Map. Demy 8vo, 106. $6 \mathrm{~d}$.

SHIRREFF (EMILY)-

A SHORT SKETCH OF THE LIFE OF FRIEDRICH FROBEL; a New Edition, including Fröhel's Letters from Dresden and Leipzig to his Wife, now first Translated into English. Crown 8vo, 2s.

HOME EDUCATION IN RELATION TO THE KINDERGARTEN. Two Lectures. Crown 8vo, 1s, $6 \mathrm{~d}$.

SHORE (ARABELLA)-

DANTE FOR BEGINNERS : a Sketch of the "Divina Commedia." With Translations, Biographical and Critical Notices, and Illus. trations. With Portrait. Crown $8 v 0,65$. 
$\operatorname{SIMKIN}(R)-$.

LIFE IN THE ARMY : Every-day Incidents in Camp, Field, and Quarters. Printed in Colours. Ohlong 4 to, 5 s.

SIMMONDS (T. L.)-

ANIMAL PRODUCTS : their Preparation, Commercial

Uses, and Value, With numerous Illustrations. Large crown 8vo, 3s. 6d.

SIMPSON $(M, C, M$.

REMINISCENCES OF A REGICIDE. Edited from the Original MSS, of Sergent Marceat, Member of the Convention, and Administrator of Police in the French Revolution of 1789 . Demy 8vo, with Illustrations and Portraits, 145.

SINNETT (A. P.)-

ESOTERIC BUDDHISM. Annotated and enlarged by the Author. Sixth and cheaper Edition, Crown $8 v 0,4 \mathrm{~s}$.

KARMA. A Novel. New Edition. Crown 8vo, 3s.

SMITH (MAFOR R. MURDOCK), R.R.-

PERSIAN ART. With Map and Woodcuts. Second Edition. Large crown 8vo, 2s.

STANLEY (H. M.) : HIS LIFE, WORKS, AND EXPLORATIONS. By the Rev, H. W. Litrle, Demy 8vo, ros. 6d.

STATHAM (H. H. - )

MY THOUGHTS ON MUSIC AND MUSICIANS. Illustrated with Frontispiece of the Entrance-front of Handel's Opera House and Musical Examples. Demy 8vo, 185 .

$S T O D D A R D(C . A$.

ACROSS RUSSIA FROM THE BALTIC TO THE DANUBE. With Numerous Illustrations. Large crown $8 \mathrm{vo}, 7 \mathrm{~s}$. $6 \mathrm{~d}$.

STOKES (MARGARET)-

EARLY CHRISTIAN ART IN IRELAND. With ro6 Woodcuts. Demy 8vo, 7s. 6d.

Cheaper Edition, Crown 8vo, $4 \mathrm{~s}$.

$\operatorname{STORY}(W . W)-$.

CASTLE ST. ANGELO. With Illustrations, Crown 8vo, 1os. 6d.

SUTCLIFFE (FOHN)-

THE SCULPTOR AND ART STUDENT'S GUIDE to the Proportions of the Human Form, with Mensurements in fect and inches of Full-Grown Figures of Both Sexes and of Various Ages. By Dr. G. Schadow. Plates reproduced by J. SuTCLrFFe, Ohlong folio, 3rs. 6d.

SUVÓROFF, LiFE OF. By Lieut.-Col. Spalding. Crown $8 \mathrm{vo}, 6 \mathrm{~s}$.

SWIFT: THE MYSTERY OF HIS LIFE AND LOVE. By the Rev. James Hav, Crown 8vo, $6 \mathrm{s.}$

$S$ YMONDS ( OHN ADDINGTON)-

ESSAYS, SPECULATIVE AND SUGGESTIVE. 2 vols. Crown 8vo, I8s.

TAINR (H. A.)-

NOTES ON ENGLAND. With Introduction by W. FrASER RAR. Eighth Edition. With Portrait. Crown 8vo, ss. 
TAIT (\%. S.)-

WHO IS THE MAN? A Tale of the Scottish Border. Crown 8vo, 15, ; in cloth, rs. 6d

TANNER (PROFESSOR), F.C.S.-

HOLT CASTLE; or, Threefold Interest in Land. Crown 8vo, 48. 6d.

JACK'S EDUCATION; OR, HOW HE LEARNT FARMING. Second Edition, Crown 8vo, 35, 6d.

TAYLOR (EDWARD R.), Head Master of the Birmingham Munticipal School of $A r t-$

ELEMENTARY ART TEACHING: An Educational and Technical Guide for Teachers and Learaers, including Infant School-work: The Work of the Standards; Freehand; Geometry; Model Drawing; Nature Drawing ; Colours; Light and Shade; Modelling and Design. With over 600 Diagrams and Illustrations. Imperial 8 vo, ros. $6 \mathrm{~d}$.

TEMPLE (SIR RICHARD), BART, M.P., G.C.S.I.-

COSMOPOLITAN ESSAYS. With Maps. Demy 8vo, $16 \mathrm{~s}$.

THOMSON (D. C.) -

THE BARBIZON SCHOOL OF PAINTERS: Corot, Rousseat, Diaz, Millet, and Daubigny. With ${ }^{2} 30$ Illustrations, including 36 FullPage Plates, of which 18 are Etchings 4 to, cloth, 425.

THRUPP (GEORGE A.) and FARR (WILLIAM)-

COACH TRIMMING. With 6o Illustrations. Crown 8vo, 2s. $6 \mathrm{~d}$.

THRUPP (THE REV, H. W.), M.A.-

AN AID TO THE VISITATION OF THOSE DISTRESSED IN MIND, BODY, OR ESTATE. Crown 8wo, 35. 6d.

TOPINARD (DR. PAUL)-

ANTHROPOLOGY. With a Preface by Professor PAuL Broca. With 49 Illustrations. Demy 8 vo, $35,6 d$.

TOVEY (LIEUT.-COL, R.E.)-

MARTIAL LAW AND CUSTOM OF WAR; or, Military Law and Jurisdiction in Troublous Times. Crown 8vo, 6s.

TRAHERNE (MAFOR)-

THE HABITS OF THE SALMON. Crown 8vo, 3s. 6d.

TRAILL $(H, D)-$.

THE NEW LUCIAN. Being a Series of Dialogues of the Dead. Demy 8 vo, ras.

TROLLOPE (ANTHONY)-

THE CHRONICLES OF BARSETSHIRE. A Uniform Edition, in 8 vols., large crown 8vo, handsomely printed, each vol. containing Frontispiece. 6s. each.

THE WARDEN and BAR.

CHESTER TOWERS, 2 vols. DR. THORNE.

FRAMLEY PARSONAGE.

THE SMALL HOUSE AT ALLINGTON. 2 vols.

LAST CHRONICLE OF BARSET. 2 vols.

LIFE OF CICERO, 2 vols. 8vo. £i 4 s. TROUP $(\mathscr{\gamma}$, ROSE)-

WITH STANLEY'S REAR COLUMN. With Portraits and Illustrations. Second Edition. Demy 8 vo, I6s.

VANDAM (ALBERT D.)-

WE TWO AT MONTE CARLO. Second Edition. Crown 8vo, rs. : in cloth, xs, 6d. 
VRRON (EUGENE)-

ASTHETICS. Translated by W. H. Armstrong. Large crown 8 vo, $35.6 \mathrm{~d}$.

WALFORD (MAJOR), R.A.-

PARLIAMENTARY GENERALS OF THE GREAT CIVIL WAR. With Maps, Large crown $8 \mathrm{vo}$, is.

WALKER (MRS.)-

UNTRODDEN PATHS IN ROUMANIA. With 77 Illustrations, Demy 8vo, 10s. 6d.

EASTERN LIFE AND SCENERY, with Excursions to Asia Minor, Mitylene, Crete, and Roumania, a vols., with Frontispiece to each vol. Crown Bvo, 2Is.

WALL $(A$.) -

A PRINCESS OF CHALCO. With Illustrations. Crown $8 \mathrm{vo}, 6 \mathrm{~s}$.

WARD (JAMES)-

ELEMENTARY PRINCIPLES OF ORNAMENT. With 122 Illustrations in the text. $8 \mathrm{vo}, 55$.

WATSON $($ FOHN)-

POACHERS AND POACHING. With Frontispiece. Crown 8vo, 75. 6d.

SKETCHES OF BRITISH SPORTING FISHES. With Frontispiece. Crown 8vo, 3s. 6d.

WEGG-PROSSER $(F, R)-$.

GALILEO AND HIS JUDGES. Demy 8vo, $5 \mathrm{~s}$.

WELLS (HENRY P.)-

CITY BOYS IN THE WOODS; or, A Trapping Venturein Maine. With upwards of $x 00$ Illustrations. Royal 8vo, gs.

WHITE (WALTER)-

A MONTH IN YORKSHIRE. With a Map. Fifth Edition. Post 8vo, 4 s.

A LONDONER'S WALK TO THE LAND'S END, AND A TRIP TO THE SCILLY ISLES. With 4 Maps. Third Edition. Post 8vo, 45. WORNUM $(R, N)-$.

ANALYSIS OF ORNAMENT: THE CHARACTERISTICS OF STYLES. An Introduction to the History of Ornamental Art. With many Illustrations. Ninth Edition. Royal 8vo, cloth, 8s.

WRIGHTSON (PROF. FOHN), M.R.A.C., F.C.S., E.c.; President of the College of Agriculture, Downton.

PRINCIPLES OF AGRICULTURAL PRACTICE AS AN INSTRUCTIONAL SUBJECT. With Geological Map. Second Edition. Crown 8vo, 5 s.

FALLOW AND FODDER CROPS. Crown 8vo, $5 \mathrm{~s}$. WORSAAE (F. F. A.)-

INDUSTRIAL ARTS OF DENMARK, FROM THE EARLIEST TIMES TO THE DANISH CONQUEST OF ENGLAND. With Maps and Woodcuts. Large crown 8vo, $356 \mathrm{~d}$.

YOUNG OFFICER'S "DON'T"; or, Hints to Youngsters on Joining. 32mo, 15 .

YOUNGE (C. D.)-

PARALLEL LIVES OF ANCIENT AND MODERN HEROES. New Edition, I2mo, cloth, 4s. 6 d. 
SOUTH KENSINGTON MUSEUM SCIENCE AND ART HANDBOOKS.

Handsomely printed in large crown 8vo.

Published for the Committee of the Cowncil on Education.

MARINE ENGINES AND BOILERS. By George C. V. Holmks, Secretary of the Institution of Naval Architects, Whitworth Scholar. With Sixty-nine Woodeuts. Large crown 8vo, 3 s.

EARLY CHRISTIAN ART IN IRELAND. By MARgarET STokes. With ro6 Woodcuts. Crown 8vo, 45 .

A Lihrary Edition, demy 8vo, 75. 6d.

FOOD GRAINS OF INDIA. By Prof. A. H. Сhurch, M.A., F.C.S., F.I.C. With Numerous Woodeuts. Small 4 to, 6 s.

THE ART OF THE SARACENS IN EGYPT. By STANLEY LANe POoLE, B.A., M.A.R.S. With xo8 Woodcuts. Crown 8vo, 4s,

ENGLISH PORCELAIN : A Handbook to the China made in England during the r8th Century. By Prof. A. H. Crurch, M.A. With. numerous Woodcuts. 35.

RUSSIAN ART AND ART OBJECTS IN RUSSIA: A Handhook to the reproduction of Goldsmiths' work and other Art Treasures from that country in the South Kensington Museum. By Alfred MAskeli. With Illustrations. 45. 6d.

FRENCH POTTERY. By Paul Gasnault and Edouard GArniEr. With Illustrations and Marks. 75.

ENGLISH EARTHENWARE: A Handbook to the Wares made in England during the 17 th and 18 th Centuries. By Pros. A. H. Сauscu, M,A. With numerous Woodcuts. 3 s,

INDUSTRIAL ARTS OF DENMARK. From the Earliest Times to the Danish Conquest of England. By J. J. A. WorsaAe, Hon. F.S.A., Times to the Danish Conquest of England. With Map and Woodcuts. 35. 6d.

INDUSTRIAL ARTS OF SCANDINAVIA IN THE PAGAN TIME. By HANs HILDEgRanid, Royal Antiquary of Sweden. With numerous Woodcuts. 2s. $6 \mathrm{~d}$.

PRECIOUS STONES: Considered in their Scientific and Artistic relations By Pror. A. H. Снurch, M.A. With a Coloured Plate and Woodents. 25. 6d.

INDUSTRIAL ARTS OF INDIA. By Sir GEORGE C. M. BraDWood, C.S.I., \&c. With Map and Woodeuts. Demy 8vo, 14s.

HANDBOOK TO THE DYCE AND FORSTER COLLECTIONS in the South Kensington Museum, With Portraits and Facsimiles. 2s, 6d.

INDUSTRIAL ARTS IN SPAIN. By JUAN F. RIAÑo. With numerous Woodcuts. $4 \mathrm{~s}$.

GLASS. By Alexander Nesbitt. With numerous Woodcuts. 2s. 6d.

GOLD AND SILVER SMITHS' WORK. By JOHN HungerFORD POLLEN, M.A. With numerous Woodcuts. 25. 6d.

TAPESTRY. By Alfred de Champeaux. With Woodcuts, 2s. 6d.

BRONZES. By C. Drury E. Fortnum, F.S.A. With numerous Woodcuts. 25, 6d. 
SOUTH KENSINGTON MUSEUM SCIENCE \& ART HANDBOOKS-Continued.

PLAIN WORDS ABOUT WATER. By A. H. Church, M.A. Oxon. With Illustrations. Sewed, 6d.

ANIMAL PRODUCTS : their Preparation, Commercial Uses, and Value. By T, L. Sumonds. With Illustrations. 3s. 6d.

FOOD : Some Account of its Sources, Constituents, and Uses. By Promzssor A. H. Сnurch, M.A. Oxon. New Edition, enlarged. 3 s.

ECONOMIC ENTOMOLOGY. By ANDrew Murray, F.L.S. APTERA, With Illustrations, 75, 6d.

JAPANESE POTTERY. Being a Native Report. With an Introduction and Catalogue by A. W. Franks, M.A., F.R.S., F.S.A. With Illustrations and Marks, 2s, $6 \mathrm{~d}$.

HANDBOOK TO THE SPECIAL LOAN COLLECTION of Scientific Apparatus. 3s.

INDUSTRIAL ARTS : Historical Sketches. With Numerous Illustrations. $3^{\text {s. }}$

TEXTILE FABRICS. By the Very Rev. Daniel Rock, D.D. With numerous Woodcuts. $35.6 \mathrm{~d}$.

JONES COLLECTION IN THE SOUTH KENSINGTON MUSEUM, With Portrait and Woodeuts. 25, $6 \mathrm{~d}$.

COLLEGE AND CORPORATION PLATE. A Handbook to the Reproductions of Silver Plate in the South Kensington Museum from Celebrated English Collections, By WILFRird Josepr Criprs, M.A., F.S.A. With Illustrations. 25, 6d.

IVORIES: ANCIENT AND MEDIÆVAL. By WILLIAM MAskent. With numerous Woodcuts, 2s, 6d.

ANCIENT AND MODERN FURNITURE AND WOODWORK. By JoHN Hungeryord POLLes, M.A. With numerous Woodcuts. 25. $6 \mathrm{~d}$.

MAIOLICA. By C. Drury E. Fortnum, F.S.A. With numerous Woodcuts. $28.6 \mathrm{~d}$.

THE CHEMISTRY OF FOODS. With Microscopic Illustrations. By JAMes BzL., Ph.D., \&c., Principal of the Somerset House Laboratory. Part 1.-Tea, Coffec, Cocoa, Sujar, \&c. 2s. 6d.

Part It.-Milk, Butter, Cheese, Cereals, Prepared Starches, \&c. $3^{\text {s. }}$

MUSICAL INSTRUMENTS. By CaRL ENGEL. With numerous Woodcuts. 25. $6 \mathrm{~d}$.

MANUAL OF DESIGN. By Richard Redgrave, R.A. By Gilbert R. Rederave. With Woodcuts. 2s, 6d.

PERSIAN ART. By Major R. Murdock Smith, R.E. With Map and Woodcuts. Second Edition, enlarged. 25. 


\section{CARLYLE'S (THOMAS) WORKS.}

\section{THE ASHBURTON EDITION.}

New Edition, handsomely printed, containing all the Portraits and Illustrations, in Seventeen Volumes, demy 8v0, 8s. each.

THE FRENCH REVOLUTION AND PAST AND PRESENT. 2 vols. SARTOR RESARTUS; HEROES AND HERO WORSHIP. $I$ vol. LIFE OF JOHN STERLING-LIFE OF SCHILLER. I vol.

LATTER-DAY PAMPHLETS-EARLY KINGS OF NORWAYESSAY ON THE PORTRAIT OF JOHN KNOX. $x$ vol.

LETTERS AND SPEECHES OF OLIVER CROMWELL. 3 vols. HISTORY OF FREDERICK THE GREAT. 6 vols. CRITICAL AND MISCELLANEOUS ESSAYS. 3 vols.

\section{LIBRARY EDITION COMPLETE.}

Handsomely printed in 34 vols, demy $8 v 0$, eloth, 2138. SARTOR RESARTUS. With a Portrait, 7s. 6d.

THE FRENCH REVOLUTION. A History. 3 vols., each 9 s.

LIFE OF FREDERICK SCHILLER AND EXAMINATION OF HIS WORKS. With Supplement of $18 g_{72}$. Portrait and Plates, gs.

CRITICAL AND MISCELLANEOUS ESSAYS. With Portrait. 6 vols., each gs.

ON HEROES, HERO WORSHIP, AND THE HEROIC IN HISTORY. 7s. 6d.

PAST AND PRESENT, 9s.

OLIVER CROMWELL'S LETTERS AND SPEECHES. With Portraits. 5 vols., each gs.

LATTER-DAY PAMPHLETS. 9s.

LIFE OF JOHN STERLING. With Portrait, 9s.

HISTORY OF FREDERICK THE SECOND. Io vols., each gs.

TRANSLATIONS FROM THE GERMAN. 3 vols., each 9s. EARLY KINGS OF NORWAY; ESSAY ON THE POR. TRAITS OF JOHN KNOX; AND GENERAL INDEX. With Portrait Itlastrations. 8vo, cloth, qs, 


\section{CHEAP AND UNIFORM EDITION. \\ 23 vols., Crown 8vo, cloth, $\$ 75^{\text {s. }}$}

THE FRENCH REVOLUTION : A History. 2 rols., 125.

OLIVER CROMWELL'S LET. TERS AND SPEECHES, with Elucidations, \&c. 3 vols., $18 \mathrm{~s}$.

LIVES OF SCHILLER AND JOHN STERLING. $x$ vol., $6 s$.

CRITICAL AND MISCEILA. NEOUS ESSAYS. 4 vols., $6 \mathrm{I} 4 \mathrm{~s}$.

SARTOR RESARTUS AND LECTURES ON HEROES, x rol., 6 s.
LATTER-DAY PAMPHLETS. I vol., 6 s.

CHARTISM AND PAST AND PRESENT. I rol., 6s.

TRANSLATIONS FROM THE GERMAN OF MUSEUS, TIECK, AND RICHTER. $x$ vol., 65.

WILHELM MEISTER, by Göethe. A Translation. 2 vols, res.

HISTORY OF FRIEDRICH THE SECOND, called Frederick the Great. 7 rols., $6_{2} g \mathrm{~s}$.

\section{PEOPLE'S EDITION.}

37 vols., small crown 8vo, 37 s.; sefarate vols., Is. each.

SARTOR RESARTUS. With Portrait of Thomas Carlyle.

FRENCH REVOLUTION. A History. 3 rols.

OLIVER CROMWELL'S LET. TERS AND SPEECHES. 5 vols, With Portrait of Oliver Cromwell.

ON HEROES AND HERO WORSHIP AND THE HEROIC IN HISTORY.

PAST AND PRESENT.

CRITICAL AND MISCELLA-

Or in sets, 37 vols. in 18,37 s. 2 rols. NEOUS ESSAYS. 7 vols,

THE LIFE OF SCHILLER, AND EXAMINATION OF HIS WORKS. With Portrait.

LATTER-DAY PAMPHLETS.

WILHELM MEISTER. 3 vols.

LIFE OF TOHN STERLING. With Portrait.

HISTORY OF FREDERICK THE GREAT. ro vols.

TRANSLATIONS FROM MUSAUS, TIECK, AND RICHTER.

THE EARLY KINGS OF NOR. WAY; Essay on the Portraits of Knox.

CHEAP ISSUE.

THE FRENCH REVOLUTION. Complete in I vol. With Portrait. Crown 8vo, 2s.

SARTOR RESARTUS, HEROES AND HERO WORSHIP, PAST AND PRESENT, AND CHARTISM. Complete in $x$ vol. Crown $8 \mathrm{ro}, 25$.

OLIVER CROMWELL'S LETTERS AND SPEECHES. Crown 8vo, 25. $6 \mathrm{~d}$.

CRITICAL AND MISCELLANEOUS ESSAYS. 2 vols. 45.

WILHELM MEISTER, I vol. 2S,

SIXPENNY EDITION.

$$
\text { 4to, sewed. }
$$

SARTOR RESARTUS. Eightieth Thousand.

HEROES AND HERO WORSHIP.

ESSAYS : Burns, Johnsen, Scots, Thr Diamond Necklact.

The abouse in I vol., cloth, 2s. 6d. 


\section{DICKENS'S (CHARLES) WORKS.}

ORIGINAL EDITIONS.

In demy 8vo.

THE MYSTERY OF EDWIN DROOD. With Illustrations by S. L. Fildes, and a Portrait engraved by Baker. Cloth, 7s. $6 \mathrm{~d}$.

OUR MUTUAL FRIEND. With Forty Illustrations by Marcus Stone. Cloth, $£ \mathrm{I}$ is.

THE PICKWICK PAPERS. With Forty-three Illustrations by Seymour and Phiz. Cloth, $€ \mathrm{I}$ is.

NICHOLAS NICKLEBY. With Forty Illustrations by Phiz. Cloth, לI Is.

SKETCHES BY "BOZ." With Forty Illustrations by George Crivilsshank. Cloth, \&I Is.

MARTIN CHUZZLEWIT. With Forty Illustrations by Phiz. Cloth, \&I Is.

DOMBEY AND SON. With Forty Illustrations by Phiz. Cloth, $\notin \times$ is.

DAVID COPPERFIELD. With Forty Illustrations by Phiz. Cloth, 6I Is.

BLEAK HOUSE. With Forty Illustrations by Phiz. Cloth, 6I is.

LITTLE DORRIT. With Forty Illustrations by Phiz. Cloth, fI 1 .

THE OLD CURIOSITY SHOP. With Seventy-five Illustrations hy George Cattermole and H. K. Browne. A New Edition. Uniform with the other volumes, $6 \times$ Is.

BARNABY RUDGE: a Tale of the Riots of 'Eighty. With Seventy-eight Illustrations hy George Cattermole and H. K. Browae. Uniform with the other volumes, $\notin \mathrm{x}$ is.

CHRISTMAS BOOKS: Containing-The Christmas Carol ; The Cricket on the Hearth; The Chimes; The Battle of Life; The Haunted Honse. With all the original Mllustrations. Cloth, $\mathbf{x 2 s .}$

OLIVER TWIST and TALE OF TWO CITIES. In one volume Cloth, $6 \mathrm{I}$ is

OLIVER TWIST. Separately. With Twenty-four Illustrations by George Cruikshank. Cloth, IIs.

A TALE OF TWO CITIES. Separately. With Sixteen Illustrations hy Phiz, Cloch, gos

" * The remainv'er of Dickens's Works were not originally printed in demy 8va. 


\section{DICKENS'S (CHARLES) WORKS.-Continued.}

\section{LIBRARY EDITION.}

In post 8vo. With the Original Illustrations, 30 vols., cloth, tor2.

PICKWICK PAPERS ... $\quad \ldots \quad \ldots . \quad \ldots \quad \ldots \quad \ldots 43$ Illustrns., 2 vols. I6 If $^{d .}$

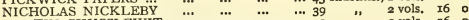

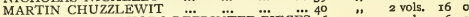
OLD CURIOSITY SHOP \& REPRINTED PIECES $3^{6}$ ", 2 vols. 160 BARNABY RUDGE and HARD TIMES ... $\ldots 3^{6} \quad$ ". 2 vols. I6 BIEAK HOUSE $\ldots$

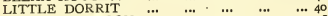

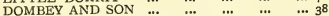

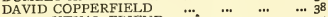

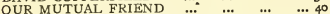

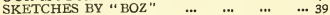

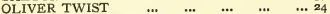

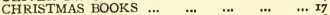

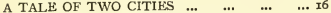

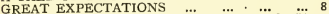
PICTURES FROM ITALY \& ÄMERICAN NOTES 8

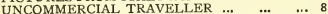
CHILD'S HISTORY OF ENGLAND $\ldots . . . .8$ CHIN DROOD and MISCELLANIES '... ' CHRISTMAS STORIES from "Household Words," \&c. $x_{4}$ ", Uniform with the above, ros. $6 d$. 2 vols, I6 0 2 vols, 16 o 2 vols. $16 \circ$ 2 vols, 16 : 2 vols. 16 a I vol, 8 . I vol. 8 ० I vol. 80 I vol. 8 : I vol, 80 I vol. 80 I vol. 80 I vol. 80 I vol. 8 o I vol. 80 A NEW EDITION OF ABOVE, WITH THE ORIGINAL ILLUSTRATIONS, IN LARGE CROWN 8vo, 30 VOLS. IN SETS ONLY.

\section{THE "CHARLES DICKENS" EDITION.}

In Crown 8vo. In 21 vols, cloth, with Illustrations, $_{3}$ r6s.

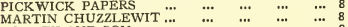
NICHOIAS NICKIEBY $\begin{array}{lllllllll}\cdots & \cdots & \cdots & \cdots & \cdots & 8 & \cdots & \cdots & 4\end{array}$

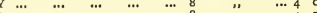

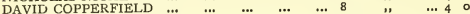
BLEAK HOUSE

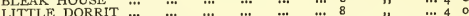

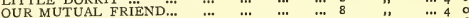

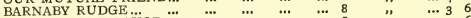

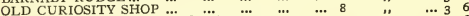

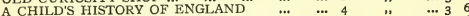

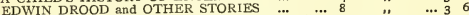
CHRISTMAS STORIES, from "Household Words " .... 8 . " $\quad \ldots 36$ SKETCHES BY "BOZ" $\ldots$...

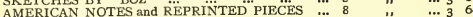

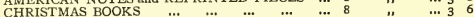

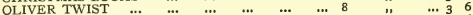

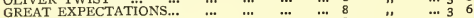
TALE OF TWO CITIES $\ldots$... $\ldots$.

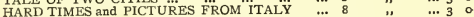

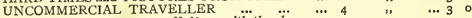




\section{DICKENS'S (CHARLES) WORKS.-Continued.}

\section{THE ILLUSTRATED LIBRARY EDITION. (WITH LIFE.) \\ Complete in 32 Volumes. Demy 8vo, ros, each; or set, f $_{16} 6$.}

This Edition is printed on a finer paper and in a larger type tban has been employed in any previous edition. Tbe type bas been cast especially for it, and tbe page is of a size to admit of the introduction of all tbe original illustrations.

No sucb attractive issue bas been made of tbe writings of Mr. Dickens, whicb, various as have been the forms of publication adapted to tbe demands of an ever widely-increasing popularity, have never yet been wortbily presented in a really bandsome library form.

Tbe collection comprises all tbe minor writings it was Mr. Dickens's wish to preserve.

SKETCHES BY " BOZ," Witb 40 Illustrations by George Cruikshank,

PICKWICK PAPERS. 2 vols. Witb 42 Illustrations by Phiz.

OLIVER TWIST. With 24 Illustrations by Cruiksbank.

NICHOLAS NICKLEBY. a vols, Witb 40 Illustrations by Pbiz.

OLD CURIOSITY SHOP and REPRINTED PIECES. 2 vols, Witb Illustrations by Cattermole, \&c.

BARNABY RUDGE and HARD TIMES. 2 vols. With Illustrations by Cattermole, \&c.

MARTIN CHUZZLEWIT. 2 vols. With 40 Illustrations by Pbiz.

AMERICAN NOTES and PICTURES FROM ITALY. I vol. With.

8 Illustrations.

DOMBEY AND SON. 2 vols. Witb 40 Illustrations by Phiz.

DAVID COPPERFIELD, 2 vols. Witb 40 Illustrations by Pbiz.

BLEAK HOUSE, 2 vols. Witb 40 Illustrations by Phiz.

LITTLE DORRIT. 2 vols. Witb 40 Illustrations by Pbiz.

A TALE OF TWO CITIES. With $x$ Illustrations by Pbiz.

THE UNCOMMERCIAL TRAVELLER. Witb 8 Illustrations by Marcus Stone.

GREAT EXPECTATIONS. Witb 8 Illustrations by Marcus Stone.

OUR MUTUAL FRIEND. 2 vols. Witb 40 Illustrations by Marcus Stone.

CHRISTMAS BOOKS. With I7 Illustrations by Sir Edwin Landseer, R.A., Maclise, R.A., \&c. \&c.

HISTORY OF ENGLAND, Witb 8 Illustrations by Marcus Stone.

CHRISTMAS STORIES. (From "Household Words" and "All the Year Round.") With $x_{4}$ Illustrations.

EDWIN DROOD AND OTHER STORIES. With I2 Illustrations by S, L. Fildes.

LIFE OF CHARLES DICKENS. By Jobn Forster. Wh Portraits. 2 vols. (Not separate.) 


\section{DICKENS'S (CHARLES) WORKS.-Continued. THE POPULAR LIBRARY EDITION}

In 30 Vols., large crown 8vo, price $£ 6$; separate Vols. 4 s each.

An Edition printed on good paper, each volume containing 16 full-page Illustrations, selected from the Household Edition, on Plate Paper.

SKETCHES BY "BOZ."
PICKWICK. 2 vols.
OLIVER TWIST.
NICHOLAS NICKLEBY. 2 vols.
MARTIN CHUZZLEWIT. 2 vols.
DOMBEY AND SON. 2 vols.
DAVID COPPERFIELD. 2 vols,
CHRISTMAS BOOKS.
OUR MUTUAL FRIEND. 2 vols.
CHRISTMAS STORIES.
BLEAK HOUSE. 2 vols.
LITTLE DORRIT. 2 vols.
OLD CURIOSITY SHOP ANI REPRINTED PIECES. 2 vols. BARNABY RUDGE. 2 vols, UNCOMMERCIAL TRAVELLER. GREAT EXPECTATIONS. TALE OF TWO CITIES. CHILD'S HISTORY OF ENGLAND.

EDWIN DROOD AND MISCEL. LANIES.

PICTURES FROM ITALY AND AMERICAN NOTES.

\section{HOUSEHOLD EDITION.}

\section{(WITH LIFE.)}

In 22 Volumes. Crown 4 to, cloth, $£ 48$ s, $6 d$.

MARTIN CHUZZLEWIT, with 59 Illustrations, 5 s.

DAVID COPPERFIELD, with 60 Illustrations and a Portrait, 55 .

BLEAK HOUSE, with 6 I Illustrations, 5 s.

LITTLE DORRIT, with 58 Illustrations, 5 s.

PICKWICK PAPERS, with 56 Illustrations, 5 s.

OUR MUTUAL FRIEND, with 58 Illustrations, 5s.

NICHOLAS NICKLEBY, with 59 Illustrations, 55 .

DOMBEY AND SON, with $6 x$ Illustrations, 5 s.

EDWIN DROOD; REPRINTED PIECES; and other Stories, with zo Illustrations, $5 \mathrm{~s}$.

THE LIFE OF DICKENS. By JOHN FORsTrR. With 40 Illustrations, 5 . BARNABY RUDGE, with 46 Illustrations, 45 . OLD CURIOSITY SHOP, with 32 Illustrations, 4 s.

CHRISTMAS STORIES, with 23 Illustrations, 45 .

OLIVER TWIST, with 28 Illustrations, $3^{5}$.

'GREAT EXPECTATIONS, with 26 Illustrations, 3 s. SKETCHES BY " $\mathrm{BOZ}$," with $3^{6}$ Illustrations, 3 s.

UNCOMMERCIAL TRAVELLER, with 26 Illustrations, 3 .

CHRISTMAS BOOKS, with 28 Illustrations, 3 s.

THE HISTORY OF ENGLAND, with 5 Illustrations, 35 .

AMERICAN NOTES and PICTURES FROM ITALY, with $x 8$ Illustrations, 35 ,

A. TALE OF TWO CITIES, with 25 Illustrations, 3 s.

MARD TIMES, with 20 Illustrations, 25. $6 \mathrm{~d}$. 
DICKENS'S (CHARLES) WORKS.-Continued.

\section{THE GROWN EDITION,}

COMPLETE IN I7 VOLUVES.

Containing ALL THE ORIGINAL ILLUSTRATIONS, And the Letterpress is printed from Type expressly cast for this Edition. LARGE CROWN OCTAVO.

PRICE FIVE SHILLINGS EACH.

ז.-THE PICKWICK PAPERS. With Forty-three Illustrations by SEYMOUR and PHIz.

2.-NICHOLAS NICKLEBY. With Forty Illustrations by PHIZ,

3.-DOMBEY AND SON. With Forty Illustrations by PHIz.

4.-DAVID COPPERFIELD. With Forty Illustrations by Priz.

5.-SKETCHES BY "BOZ." With Forty Illustrations by Geo. CRUIKSHANK.

6.-MARTIN CHUZZLEWIT. With Forty Illustrations by PHiz.

7.-THE OLD CURIOSITY SHOP, With Seventy-five Illustrations by Grorge CATtermole and H. K. Brownz.

8.-BARNABY RUDGE : a Tale of the Riots of 'Eighty. With Seventyeight Illustrations by George CatTrRmole and H. K. Browne.

9.-OLIVER TWIST and TALE OF TWO CITIES. With Twenty-four Illustrations by CrUiksHa NK and Sixteen by PHiz.

Io,-BLEAK HOUSE. With Forty Illustrations by PHIz.

II.-LITTLE DORRIT. With Forty Illustrations by PHIz.

52.-OUR MUTUAL FRIEND. With Forty Illustrations by MARcus STONE.

13.-AMERICAN NOTES ; PICTURES FROM ITALY; and A CHILD'S HISTORY OF ENGLAND. With Sixteen Illustrations by MARCUS STONE.

14.-CHRISTMAS BOOKS and HARD TIMES. With Illustrations by Landseer, Maclise, Stanfield, Leech, Doxle, F. WALKER, etc.

15.-CHRISTMAS STORIES AND OTHER STORIES, including HUMPHREY'S CLOCK. With Illustrations by DALZIEI, Charles Green, Mahoney, Phiz, Cattermole, etc.

16.-GREAT EXPECTATIONS. UNCOMMERCIAL TRAVELLER. With Sixteen Illustrations by MARcuS STONE.

47.-EDWIN DROOD and REPRINTED PIECES. With Sixteen Illustrations by LUKE FILDES and F. WALKer.

$$
\text { Uniform with the above. }
$$

THE LIFE OF CHARLES DICKENS. By JOHN ForsTeR. With Portraits and Illustrations. Will be added at the request of numerous Subscribers.

THE DICKENS DICTIONARY. A Key to the Characters and Principal Incidents in the Tales of Charles Dickens. Fy GiLBerT PIERCE, with Additions by WILITAM A. WhKELER. 


\section{DICKENS'S (CHARLES) WORKS.-Continued. THE CABINET EDITION.}

In 32 vols. small fcap. 8vo, Marble Paper Sides, Cloth Backs, with uncut edges, price Eighteenpence each.

Each Volume contains Eight Illustrations reproduced from the Originals.

In Sets only, bound in blue cloth, with cut edges, $t_{2} 8 s$.

CHRISTMAS BOOKS.

MARTIN CHUZZLEWIT, 2 vols.

DAVID COPPERFIELD, 2 vols.

OLIVER TWIST.

GREAT EXPECTATIONS.

NICHOLAS NICKLEBY, 2 vols.

SKETCHES BY "BOZ."

CHRISTMAS STORIES.

THE PICKWICK PAPERS, 2 vols.

BARNABY RUDGE, 2 vols.

BLEAK HOUSE, 2 vols.

AMERICAN NOTES AND PIC-

TURES FROM ITALY.
EDWIN DROOD; AND OTHER STORIES.

THE OLD CURIOSITY SHOP, 2 vols.

A CHILD'S HISTORY OF ENGLAND.

DOMBEY AND SON, 2 vols.

A TALE OF TWO CITIES.

LITTLE DORRIT, 2 vols.

MUTUAL FRIEND, 2 vols.

HARD TIMES.

UNCOMMERCIAL TRAVELLER

REPRINTED PIECES.

\section{CHARLES DICKENS'S CHRISTMAS BOOKS.}

REPRINTED FROM THE ORIGINAL PLATES,

Illustrated by JOHN LEECH, D. MACLISE, R.A., R, DOYLE, C. STANFIELD, R.A., etc.

Fcap, cloth, $1 s$, each, Complete in a case, 5 s.

A CHRISTMAS CAROL IN PROSE.

THE CHIMES : A Goblin Story.

THE CRICKET ON THE HEARTH: A Fairy Tale of THE BATTLE OF LIFE. A Love Story.

THE HAUNTED MAN AND THE GHOST'S STORY. SIXPENNY REPRINTS of DICKENS'S WORKS. DAVID COPPERFIELD, With numerous Illustrations by OLIVER TWIST. With 28 Illustrations by J. MAHONEY. Medium Bvo.

READINGS FROM THE WORKS OF CHARLES DICKENS. As selected and read by himself and now published for the first time. Illustrated. A CHRISTMAS CAROL, AND THE HAUNTED MAN. Illustrated.

THE CHIMES: A Goblin STORY, AND THE CRICKET ON THE HEARTH. Illustrated.

THE BATTLE OF LIFE: A Love STORY, HUNTED DOWN, AND A HOLIDAY ROMANCE. Illustrated. 
DICKENS'S (CHARLES) WORKS.-Continued. A NEW EDITION, ENTITLED

\section{THE PICTORIAL EDITION, Now being issued in Monthly PARTs, royal 8vo, at ONE SHILLING EACH.}

Each Part containing 192 pages of Letterpress, handsomely printed, and, besides full-page Plates on plate paper, about 24. Illustrations inserted in the Text.

The Edition will be completed in about ThIRTy-Seven PARTS, of which Thirty are now ready, and will contain in all-

UPWARDS OF NINE HUNDRED ENGRAVINGS. Cases for Binding the Parts in Volumes can be supplied.

The Volumes now realy are:

DOMBEY AND SON. With OUR MUTUAL FRIEND. 62 Illustrations by F. BArNard. 35, 6d, With ${ }_{5} B$ Illustrations by J. MAronsy.

DAVID COPPERFIELD. With GI lllustrations by F. Barnard. $3^{5.6 \mathrm{~d} .}$.

NICHOLAS NICKLEBY. With 59 1llustrations by $\mathrm{F}$. BARNARD, 3. $6 \mathrm{~d}$.

BARNABY RUDGE, With 46 Illustrations by F. Barkard. 3s, 6d.

OLD CURIOSITY SHOP. With 39 Illustrations by CHArLes Gren. 3.. 6d.

MARTIN CHUZZLEWIT. With 59 lllustrations by F. BARNARd. 3s. $6 \mathrm{~d}$.

OLIVER TWIST and A TALE OF TWO CITIES. With 53 Illustrations by J. MaHoney and F. BARNard. 3.4, 6d. 35. $6 \mathrm{~d}$.

BLEAK HOUSE. With 6I Illustrations by F. BARNARD, 35. 6d,

PICKWICK PAPERS. With 57 llustrations by Purz. 35, 6d.

LITTLE DORRIT. With $5^{8}$ Illustrations by $J$. M AHoneY. 35. 6d.

GREAT EXPECTATIONS \& HARD TIMES. With so Illustrations by J.A. FrAsgrand H. FRrNCH. 35.6d.

AMERICAN NOTES, PICTURES FROM ITALY, and A CHILD'S HISTURY OF ENGLAND. With 33 Illustrations by Frost, GordoN, Thosison, and Rulston. 35. 6d.

SKETCHES BY "BOZ" and CHRISTMAS BOOKS. With 62 Illus. trations by F. BAR NARD. [In the Press.

\section{THE TWO SHILLING EDITION.} Each Volume contains a Frontispiece. Crown 8vo, 2 s.

The Volumes now ready are-

DOMBEY AND SON.

MARTIN CHUZZLEWIT.

THE PICKWICK PAPERS.

BLEAK HOUSE.
OLD CURIOSITY SHOP.

BARNABY RUDGE.

DAVID COPPERFIELD.

NICHOLAS NICKLEBY.

OUR MUTUAL FRIEND.

\section{MR. DICKENS'S READINGS.}

Fcap. 8vo, sewed.

CHRISTMAS CAROL IN | STORY OF LITTLE DOM. PROSE. Is.

CRICKET ON THE HEARTH. Is.

CHIMES : A GOBLIN STORY. Is.

BEY. Is.

POOR TRAVELLER, BOOTS

AT THE HOLLY-TREE INN, and MRS. GAMP. Is. 


\section{SCIENCE AND ART,}

AND TECHNICAL EDUCATION.

\section{A \$ournal for Teachers and stuoents.}

The Official Organ of the Science and Art Teachers' Association. Edited by JоHN MILLs.

MONTHLY, THREEPENCE; POST FREE, FOURPENCE.

The Journal contains contributions by distinguished men; short papers by prominent teacbers ; leading articles; correspondence; answers to questions set at tbe May Examinations of the Science and Art Department; and interesting news in connection with the scientific and artistic world.

\section{PRIZE COMPETITION.}

With each issue of the Journal, papers or drawings are offered for Prize Competition. extending over the range of subjects of tbe Science and Art Department and City and Guilds of London Institute.

There are thousands of Science and Art Scbools and Classes in the United Kingdom, but the teachers connected wilh these institutions, although engaged in the advancement of identical objects, are seldom known to each other except through personal friendship. One object of the Journal is to enable those engaged in this common work to com: municate upon subjects of importance, witb a view to an interchange of ideas, and the establishment of unity of action in the various centres.

\section{TERMS OF SUBSCRIPTION.}

ONE YEAR'S SUBSCRIPTION (including postage) HALF "

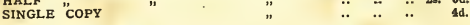

Cheques and Post Office Orders to be made payable to

Messrs. CHAPMAN \& HALL, : Limited, Agents for the Science and Art Department of the Committee of Councll on Education.

SOLUTIONS TO THE QUESTIONS SET IN THE FOLLOWING SUBJECTS AT THE MAY EXAMINATIONS OF THE SCIENCE AND ART DEPARTMENT ANTERIOR TO 1887 .

I. Animal Physiology _.. From I881 to I886.

2. Hygiene $\ldots \quad \ldots \quad \ldots \quad, \quad 1884$ to $1886\left\{\begin{array}{l}\text { with Notes } \\ \text { and Index }\end{array}\right.$

3. Building Construction ... ", 1881 to 1886 .

4. Machine Construction .... " " 1881 to 1886.

5. Agriculture … … ", I881 to 1886.

6. Magnetism and Electricity " " 1881 to 1886.

7. Physiography ... ... " " 1881 to 1886 .

8. Sound, Light, and Heat $\quad$ " 188 I to 1886.

9. Pure Mathematics ", I881 to I886.

Each Subject dealt with in a Scparale Volume, containing Complete Answers to the Eiementary and Advanced Pafers for the Years noted.

Price 1s. 6d, each, with the exception of No. 9, which is 25. 


\section{Works Published at Three Shillings and Sixpence each.}

AUSTRALIAN LIFE. By FRANCIS ADAMS.

THE SECRET OF THE PRINCESS : a Tale of Country,

Camp, Court, Convict, and Cloister Life in Russia. By Mrs. Sutherrand EDWARDS.

STORY OF AN AFRICAN FARM. By OLIVE SCHREINER.

CHRIST THAT IS TO BE, THE: A Latter-day Romance. Third Edition.

BEYOND THE SEAS; being the surprising Adventures and ingenious Opinions of Ralph, Lord St. Keyne, told hy his kinsman, Humphrey St. Keyne. By Oswald Crawrurd. Second Edition.

THE STORY OF HELEN DAVENANT. By Violet Fane. A DEPUTY PROVIDENCE. By HeNry Murray.

MY "HANSOM" LAYS: Original Verses, Imitations, and Paraphrases. By W. Bratry-Kingston.

SPORT : Fox Hunting, Salmon Fishing, Covert Shooting, Deer Stalking. By the late W. Brouley Davenport, M.P. With Illustrations hy Genaral, Ciralock, C.B.

LOG-BOOK OF A FISHERMAN AND ZOOLOGIST. By Franx BuckLand. With Illustrations. Fifth Thousand.

THE HABITS OF THE SALMON. By Major Traherne. BRITISH SPORTING FISHES. By JOHN WATSON.

ENGLAND: ITS PEOPLE, POLITY, AND PURSUITS. By T. H. S. Escotr. New and Revised Edition.

PROBLEMS OF THE FUTURE AND ESSAYS. By SAMURL LAING. Eighth Thousand.

MODERN SCIENCE AND MODERN THOUGHT. By Samugl LaING. Twelfth Thousand,

A MODERN ZOROASTRIAN. By Samuel Laing. Fifth Thousand.

THE SCIENCE OF LANGUAGE: LINGUISTICS, PHILOLOGY, AND ETYMOLOGY. By AmBL Hovelacque, With Maps.

SOCIOLOGY. Based upon Ethnology. By Dr. Charles Letournan.

Biology. By Dr. Charles Letourneau. With 83 Illustrations.

PHILOSOPHY, Historical and Critical, By ANDRÉ LeFkvRE. ANTHROPOLOGY. By Dr. PaUl Topinard, With a Preface hy Prorrssor Paul Broca. With 49 Illustrations.

AESTHETICS. By Eugene Veron.

THE IDEAL OF MAN. By ARTHUR Lovell.

AN AID TO THE VISITATION OF THOSE DISTRESSED IN MIND, BODY, OR ESTATE. By the REv. H. W. THRUPp,

ANIMAL PRODUCTS : their Preparation, Commercial Uses, and Value. By T. L. Srmosos. With Illustrations:

ECONOMIC EN'TOMOLOGY. By ANDREW MurRAy, F.L.S. Aptera. With Illustrations. 


\section{THE FORTNIGHTLY REVIEW.}

THE FORTNIGHTLY REVIEW is published on the ist of every month, and a Volume is completed every Six Months.

The following are among the Contributors:-

ADMIRAL LORD ALCESTER. GRANT ALLEN.

SIR RUTHERFORD ALCOCK. AUTHOR OF "GREATER BRITAIN," PROFESSOR BAIN.

SIR SAMUEL BAKER.

PROFESSOR BEESLY.

PAUL BOURGET.

BARON GEORGE YON BUNSEN. DR. BRIDGES.

HON. GEORGE C. BRODRICK.

JAMES BRYCE, M.P.

THOMAS BURT, M.P.

SIR GEORGE CAMPBELL, M.P.

THE EARL OF CARNARVON.

EMILIO CASTELAR.

RT. HON. J. CHAMBERLAIN, M.P. PROFESSOR SIDNEY COLVIN.

THE EARL COMPTON.

MONTAGUE COOKSON, Q.C.

L. H. COURTNEY, M.P.

G. H. DARWIN.

SIR GEORGE W. DASENT.

PROFESSOR A. V. DICEY,

PROFESSOR DOWDEN.

RT. HON. M. E. GRANT DUFF.

RIGHT HON. H. FAWCETT, M.P.

ARCHDEACON FARRAR,

EDWARD A. FREEMAN.

J. A. FROUDE.

MRS. GARRET-ANDERSON.

J. W. L. GLAISHER, F,R.S.

SIR J. E. GORST, Q.C., M.P.

EDMUND GOSSE.

THOMAS HARE.

FREDERIC HARRISON.

ADMIRAL SIR G. P. HORNBY.

LORD HOUGHTON.

PROFESSOR HUXLEY.

PROFESSOR R. C. JEBB.

ANDREW LANG.

E. B. LANIN.

EMILE DE LAVELEYE.

T. E. CLIFFE LESLIE.

W. S. LILLY.

MARQUIS OF LORNE.

PIERRE LOTI.
SIR JOHN LUBBOCK, BART,, M,P. THE EARL OF LYTTON.

SIR H. S. MAINE.

W. H. MALLOCK.

CARDINAL MANNING.

DR, MAUDSLEY.

PROFESSOR MAX MÜLLER.

GEORGE MEREDITH.

RT. HON. G. OSBORNE MORGAN, Q.C., M.P.

PROFESSOR HENRY MORLEY.

RT. HON. JOHN MORLEY, M.P.

WILLIAM MORRIS.

PROFESSOR H. N. MOSELEX.

F. W. H. MYERS.

F. W. NEWMAN.

PROFESSOR JOHN NICHOL.

W, G. PALGRAVE.

WALTER H. PATER.

RT. HON. LYON PLAYFAIR, M.P. SIR HENRY POTTINGER, BART. PROFESSOR J. R. SEELEY.

LORD SHERBROOKE.

PROFESSOR SIDGWICK.

HERBERT SPENCER.

M. JULES SIMON.

(Doctor L'Academie Francaise).

HON. E. L. STANLEY.

SIR J. FITZJAMES STEPHEN, Q.C.

LESLIE STEPHEN.

J. HUTCHISON STIRLING.

A. C. SWINBURNE.

DR. VON SYBEL,

J. A. SYMONDS.

SIR THOMAS SYMONDS. (ADMIRAL OF THE FLEET).

THE REV. EDWARD F. TALBOT

(Warden of Karte ColLegG).

SIR RICHARD TEMPLE, BART.

HON. LIONEL A. TOLLEMACHE.

COUNT LEO TOLSTOI.

H. D. TRAILL.

PROFESSOR TYNDALL.

ALFRED RUSSELL WALLACE.

A. J. WILSON.

GEN. VISCOUNT WOLSELEY.

THE EDITOR.

ETC. ETC. RTC.

Thr Fortnightly Review is pwblished at 2s. $6 d$.

CHAPMAN \& HALL, LIMITED, 11 , HENRIETTA STREET, COVENT GARDEN, W.C.

CHARLES DICKENS AND EVANS, PRINTERS, CRYSTAL PALACE FRESS. 


\section{UNIVERSITY COLLEGE, SOUTHAMPTON THE LIBRARY}

This book is to be returned to the Library on or before the last date stamped below

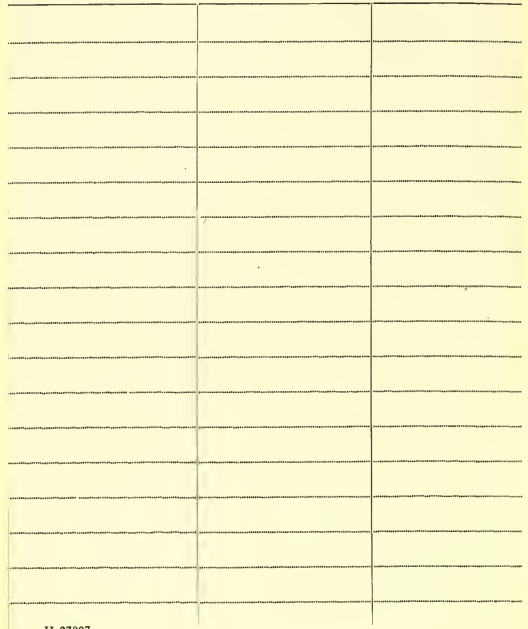

H 27807 


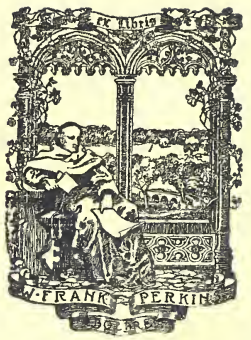




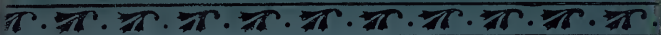

\section{1}


